\title{
Comparative ecology of widely distributed pelagic fish species in the North Atlantic: implications for modelling climate and fisheries impacts
}

\author{
V.M. Trenkel ${ }^{a, *}$, G. Huse ${ }^{b}$, B.R. MacKenzie ${ }^{c, d}$, P. Alvarez ${ }^{e}, H$. Arrizabalaga $^{e}$, M. Castonguay $^{f}$, \\ N. Goñi ${ }^{i}$, F. Grégoire ${ }^{f}$, H. Hátún ${ }^{g}$, T. Jansen ${ }^{d}$, J.A. Jacobsen ${ }^{g}$, P. Lehodey ${ }^{h}$, M. Lutcavage ${ }^{i}$, P. Mariani ${ }^{d}$, \\ G.D. Melvin', J.D. Neilson', L. Nøttestad ${ }^{\mathrm{b}}$, G.J. Óskarssonk, M.R. Payne ${ }^{\mathrm{d}}$, D.E. Richardson', I. Senina ${ }^{\text {h', }}$ \\ D.C. Speirs ${ }^{m}$
}

\footnotetext{
a Ifremer, rue de l'île d'Yeu, BP 21105, 44311 Nantes cedex 3, France.

${ }^{b}$ Institute of Marine Research -(IMR), Nordnesgate 33, 5817 Bergen, Norway.

${ }^{c}$ Center for Macroecology, Evolution and Climate and Centre for Ocean Life, National Institute of Aquatic Resources (DTU Aqua), Charlottenlund Castle, 2920 Charlottenlund, Denmark.

d Centre for Ocean Life, National Institute of Aquatic Resources (DTU Aqua), Charlottenlund Castle, 2920 Charlottenlund, Denmark.

${ }^{\text {e }}$ AZTI-Tecnalia, Herrera kaia portualdea z/g, 20110 Pasaia (Gipuzkoa), Spain.

${ }^{f}$ DFO, Institut Maurice-Lamontagne, 850 route de la mer, C.P. 1000, Mont-Joli G5H 3Z4, Canada

${ }^{9}$ Faroe Marine Research Institute (FAMRI), FO-110 Tórshavn, Faroe Islands.

${ }^{\mathrm{h}}$ CLS Satellite Oceanography Division, Ramonville St Agne, France.

' LPRC, Umass Amherst, Marine Station, Box 3188, Gloucester, MA 01931, USA

j DFO, Biological Station, 531 Brandy Cove Road, St. Andrews, E5B 2L9 Canada.

${ }^{k}$ Marine Research Institute (MRI), Skulagata 4, 121, Reykjavik, Iceland.

I NEFSC/NMFS/NOAA, 28 Tarzwell Drive, Narragansett, RI 02882, USA.

${ }^{m}$ Department of Mathematics \& Statistics, University of Strathclyde, Glasgow G1 1XH, UK

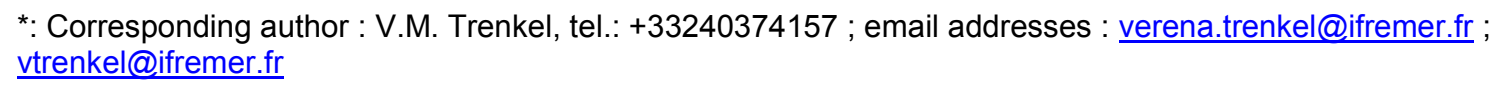

\section{Abstract:}

This paper reviews the current knowledge on the ecology of widely distributed pelagic fish stocks in the North Atlantic basin with emphasis on their role in the food web and the factors determining their relationship with the environment. We consider herring (Clupea harengus), mackerel (Scomber scombrus), capelin (Mallotus villosus), blue whiting (Micromesistius poutassou), and horse mackerel (Trachurus trachurus), which have distributions extending

beyond the continental shelf and predominantly occur on both sides of the North Atlantic. We also include albacore (Thunnus alalunga), bluefin tuna (Thunnus thynnus), swordfish (Xiphias gladius), and blue marlin (Makaira nigricans), which, by contrast, show large-scale migrations at the basin scale. We focus on the links between life history processes and the environment, horizontal and vertical distribution, spatial structure and trophic role. Many of these species carry out extensive migrations from spawning grounds to nursery and feeding areas. Large oceanographic features such as the North Atlantic subpolar gyre play an important role in determining spatial distributions and driving variations in stock size. Given the large biomasses of especially the smaller species considered here, these stocks can exert significant top-down pressures on the food web and are important in supporting higher trophic levels. The review reveals commonalities and differences between the ecology of widely 
distributed pelagic fish in the NE and NW Atlantic basins, identifies knowledge gaps and modelling needs that the EURO-BASIN project attempts to address.

\section{Highlights}

Comparative review of current knowledge on the ecology of widely distributed pelagic fish stocks in the North Atlantic basin. Emphasis on food web role and factors determining spatio-temporal distributions and changes. Overview of modelling approaches.

Keywords : Pelagic fish ecology ; North Atlantic ; Environmental drivers 
3

4

\section{Introduction}

The North Atlantic Ocean basins are home to some of the largest populations of commercially exploited stocks as well as broadly distributed fish species (Figure 1). On the NE Atlantic side, Atlantic herring (Clupea harengus), mackerel (Scomber scombrus), blue whiting (Micromesistius poutassou), horse mackerel (Trachurus trachurus), capelin (Mallotus villosus), cod (Gadus morhua) and saithe (Pollachius virens) are among the most highly exploited abundant fish species. All but horse mackerel are also found in the NW Atlantic although blue whiting is predominantly a NE Atlantic species, with only a small, unexploited western population (Bailey, 1982). Total landings from the NW Atlantic are only 23\% on average of those from the NE Atlantic (Figure 1). Conversely, Atlantic menhaden (Brevoortia tyrannus) is absent from the NE Atlantic. Most species migrate north to south and off the continental shelf, providing a link between distant areas and inshore and offshore production. Bluefin tuna (Thunnus thynnus), albacore (Thunnus alalunga), swordfish (Xiphias gladius) and blue marlin (Makaira nigricans) inhabit both shelf and open-sea parts of most of the North Atlantic basin, some carrying out large north-south and sometimes transatlantic migrations (i.e., bluefin tuna, albacore). We will concentrate on pelagic species that occur in the NE Atlantic and therefore exclude Atlantic menhaden from this review. Since saithe and cod are primarily linked to the continental shelves, we exclude them as well although they may occur pelagically.

A key characteristic of commercially important pelagic fish stocks in the North Atlantic is that they undertake extensive seasonal migrations (Arnold, 1981; Harden Jones, 1968, 1981; Leggett, 1977; Nøttestad et al., 1999). The migrations are tailored to the local current regime and the seasonal timing of ecosystem processes. The environmental conditions vary considerably across the North Atlantic and this consequently has a great impact on the spatial distribution and life history strategies of pelagic fishes.

Evidence for the interaction between fishing and climate impacts on population life history parameters (growth, maturation, recruitment), migration, spatial distributions, and food web complexity and stability has been found for a range of species (Hjerman et al., 2004). Population changes of abundant or widely distributed pelagic species will in turn impact the dynamics of lower trophic levels.

Large-scale physical oceanographic processes in the North Atlantic basin are key to understanding climate impacts. A brief summary of these processes is provided here (Figure 
1 2). The North Atlantic Oscillation (NAO) index, a metric related to the strength of the westerly

2 winds, has been the most popular climatic correlate for a wide selection of ecological variables

3 on both sides of the North Atlantic. Another metric of the physical state of the North Atlantic

4 is the Atlantic Multidecadal Oscillation (AMO) which is based on sea surface temperature

5 (SST) field.

6 NAO related atmospheric forcing mechanisms drive the dynamics of the North Atlantic

7 subpolar gyre (Eden and Willebrand, 2001). This large counter-clockwise rotating body of

8 subarctic water is produced by convection in the northwestern basins (Labrador and Irminger

9 Sea) and protrudes into the eastern basins at deeper layers. The North Atlantic Current

10 (NAC), aligned with the sub-arctic front, defines the boundary between the subpolar and

11 subtropical gyre. Changes in the extent of the subpolar gyre regulate the relative contributions

12 of western NAC water and more saline eastern water from the Bay of Biscay region, to the

13 mixing region west of the British Isles. This in turn determines the hydrography of the

14 poleward flowing Atlantic water. The characteristics of this poleward flowing Atlantic water

15 impact ecosystems all the way from the western European margin in the south to the Barents

16 Sea in the north (Holliday et al., 2008). Regional atmospheric forcing also shifts the fronts

17 between the Atlantic water and the sub-arctic water masses in the Nordic Seas (Blindheim et

18 al., 2000), which are the main foraging regions for the pelagic species reviewed here. The

19 southward flowing Arctic waters and the Atlantic waters from the Irminger Sea join in the

20 West Greenland Current, and together determine the marine climate in the Labrador Sea (Hátún

21 et al., 2007). Hence this flow regime influences the characteristics of the Labrador Current

22 which in turn contributes to the subpolar gyre. Furthermore, the Labrador Current carries

23 large amounts of freshwater originating partly from the West Greenland Current, and partly

24 from the Canadian Archipelago (Myers, 2005). This freshwater transport plays a critical role in

25 several ecosystems along the North American shelves. The outlined natural variability rides on

26 top of a secular increasing temperature trend, likely related to anthropogenic global warming

27 (IPCC, 2007).

28 Considered together and from a North Atlantic basin-wide perspective, the abiotic factors

29 affecting abundance and spatial distributions of large highly migratory predators and their prey

30 species are poorly known and constitute a major source of uncertainty for management

31 (ICCAT, 2008; Fromentin, 2009; ICES, 2009). Consequently hampering our understanding of

32 the top down influences of pelagic fish stocks on lower trophic levels. The objectives of this

33 study were to perform a comparative review of the distribution, life history and predator-prey 
1 relationships of small, medium and large pelagic fishes in the North Atlantic and to identify

2 knowledge gaps. We attempt to answer the following questions.

1) What are the commonalities and differences in distribution and life history of pelagics species across the North Atlantic?

2) What are the commonalities and differences in their trophic roles?

3) What models exist for evaluating environmental and fishieries impacts on the structure and functioning of North Atlantic ecosystems?

\section{Distribution and life history of small and medium sized pelagic fish species} in the North Atlantic

In this section we review environmental and biological factors shaping spatial patterns (spawning distributions, migration patterns), temporal patterns (spawning, migration timing), and life history parameters (hatching rates, maturity and fecundity, growth, survival) in the NE and NW Atlantic. The documented factors are summarised in table 1. Overlapping feeding areas are depicted in figure 3.

\subsection{Herring}

\subsubsection{Geographic distribution}

Atlantic herring inhabits most temperate waters of the North Atlantic. In the NW Atlantic, herring are found from Cape Hatteras in North Carolina (USA) to southern Labrador (Canada). Their distribution in the NE Atlantic extends from the Bay of Biscay, Celtic Sea and Southern North Sea in the south to Iceland and the Northern Norwegian and Barents Sea in the North. Herring is a population rich species (Sinclair and Iles, 1981; Iles and Sinclair, 1982) with numerous major and minor spawning components in each stock throughout the North Atlantic (Blaxter and Hunter, 1982; Payne 2010; Harma et al, 2012). Currently, the largest of the 20+ recognized herring stocks is the Norwegian spring-spawning herring (NSSH) with an estimated spawning stock biomass (SSB) of about 8 million tonnes in 2011 (ICES, 2011b). Other herring stocks of significance (SSB >1 million tonnes), both past and present, include those of the North Sea and Georges Bank in the Gulf of Maine, although their present levels are well below historical highs (Overholtz et al., 2004; TRAC, 2009).

\subsubsection{Spawning habitats and migrations}

Herring spawning is restricted to the central regions of their distribution. Along the North 
1 American coast most spawning occurs from Cape Cod to northern Newfoundland, while

2 off Europe/Scandinavia spawners are observed from the English Channel to southern 3 Norway (Alheit and Hagen, 1997). Physical oceanographic features affect the distribution or 4 retention of larvae (Sinclair and Isles, 1981; Grimm, 1982; Heath and MacLachlan, 1986;

5 Petitgas et al., 2010). Atlantic herring deposit demersal adhesive eggs in areas with strong 6 currents. The eggs adhere to the sea floor on a variety of substrates ranging from boulders, 7 rocks, and gravel, to sand, shell fragments, and macrophytes. The eggs remain attached to the 8 bottom throughout the incubation period.

9 Herring undertake annual migrations from their spawning grounds to summer feeding and over-wintering areas, but the extent varies between stocks. One of the main differences between NSSH and other NE Atlantic stocks is their oceanic feeding migration and that they sometimes overwinter off the shelf, i.e. outside the North Sea. For NSSH the feeding migration 13 distances increase with body size and temperature seems to play a role in determining their 14 distribution (Østvedt, 1965; Nøttestad et al., 2007). Younger fish do not undertake long 15 migrations, and spend their adolescence along the Norwegian coast or in the Barents Sea (Holst 16 and Slotte, 1998). The large amounts of food resources available due to this extended 17 distribution are thought to be important in maintaining the large NSSH stock size. Another 18 important feature is that juvenile herring inhabit the Norwegian coast and the Barents Sea reducing competition for prey with adult herring. In other stocks there is often horizontal overlap between adult and juvenile fish, though it is not uncommon to see a vertical separation 21 (Power et al., 2012).

22 In the NW Atlantic, several herring stocks undertake distant inter-annual migrations, often exceeding $1500 \mathrm{~km}$ before returning to their spawning habitat. Hence, these stocks influence several ecosystems along the continental shelf of North America. Georges Bank and the Gulf of Maine herring move south annually to the offshore waters of the Mid-Atlantic States for oyerwintering (Kanwit and Libby, 2009). The southwest Nova Scotia spawning component

27 has been found to migrate to one of two overwintering areas in the coastal waters of Nova 28 Scotia and south of Cape Cod in the USA (Stobo and Fowler, 2009). In general, northern 29 stocks tend to move south for overwintering to avoid the extremely cold winter waters 30 (Wheeler and Winters, 1984; Chadwick et al., 1993). Inter-stock mixing of adult herring is 31 known to occur during the feeding and over-wintering migrations. Juvenile herring do not undertake as extensive migrations as older fish and tend to be distributed throughout the coastal and near-shore waters of the stock in which they were larvae. There are several 
1 highly productive nursery areas where young herring aggregate as well as some mixing of 2 juvenile fish from different stocks occurs near stock boundaries. For example, 3 juvenile herring from several spawning components are known to co-exist at the mouth of 4 the Bay of Fundy. Similarly, Baltic Sea juveniles mix with North Sea juveniles in the Kattegat5 Skagerrak region (ICES, 2011a).

6 On both sides of the North Atlantic the annual migrations of some herring stocks have changed 7 spatially and temporally (Dragesund et al., 1997; Holst et al., 2002; Huse et al., 2010). 8 There have also been reports of contraction of spawning and larval distributions associated 9 with declining stock abundance and the loss of spawning components within a stock, as well 10 as expansion in distribution during increasing abundance and the colonisation of new (or 11 former) spawning grounds (Melvin and Stephenson, 2007).

12 The NSSH stock shows all these features. Variations in the southern extent of spawning areas 13 are believed to be due to the experience and condition of individuals making up the 14 population, and the latitude of the overwintering area (Slotte, 1999). Large herring positioned 15 south in the overwintering area will spawn further south than small herring overwintering far 16 north. The overwintering grounds in the 1950s and 1960s were east of Iceland, and the feeding 17 areas were mainly north and east of Iceland. Spawning was on the shelf to the west of the 18 Norwegian coast, although the southern boundary for spawning moved north as biomass 19 decreased (Dragesund et al., 1997). After the stock collapsed at the end of the 1960s, the 20 NSSH stayed close to the Norwegian coast both during overwintering and the feeding period. 21 When the stock abundance again increased in the late 1980s, the overwintering area was in 22 fjords in Northern Norway and the feeding area was throughout the Norwegian Sea. During the 23 1990s overwintering took place primarily in the Vestfjord system, but it has gradually shifted 24 northwards to open sea areas outside Troms $\emptyset$. The changes in overwintering area are typically 25 initiated when particularly abundant cohorts enter the spawning stock (Huse et al., 2010). This 26 is likely linked to absence of social learning between the old and young cohorts when the 27 younger fish are too numerous (McQuinn, 1997; Corten, 2002; Huse et al., 2002). Migration 28 patterns of herring in the North Sea, Irish Sea and around Iceland have also changed over time 29 in response to changes in population abundance and environmental conditions (Maravelias, 30 1997; Corten, 2002; Oskarsson et al., 2009).

31 In the NW Atlantic changes in the migration patterns over the past couple of decades have 32 been observed in the Southwest Nova Scotia spawning component (Kanwit and Libby, 2009) 33 and in spring and autumn spawners in the southern Gulf of St. Lawrence (Chadwick, 1993). 
1 This may be due to decreased abundance and/or warmer water. For some herring populations it

2 has been suggested that annual migrations are guided by inter-cohort social learning (Corten,

3 1999, 2002; McQuinn, 1997; Fernö et al., 1998; Slotte, 1999; Huse et al. 2002) while others

4 argue that imprinting at a young age is the driving mechanism (Isles et al., 1985). Alternative

5 mechanisms are a genetically controlled sense of direction developed during their larval phase

6 (Iles and Stochasky, 1985), habitat pheromones (Kieffer and Colgan, 1992), or larval

7 imprinting (Brophy et al., 2006; Horrall, 1981). Feeding migration seems to be driven by a

8 combination of predictive and reactive mechanisms (Fernö et al., 1998). The herring seem to

9 use some kind of memory to actively seek areas used in previous years. If environmental

10 changes lead to reduced quality in the traditional feeding areas, the herring will stay faithful to

11 these areas for some time.

12 The horizontal and vertical diel distribution of Atlantic herring is dynamic, and differs for 13 larvae, juvenile, and adults (Huse and Toresen, 1996; Huse et al., 2012; Utne et al., 14 2012b). Most herring, regardless of size and time of the year, undertake some degree of diel 15 migration moving up in the water column at night and down during the day (Heath et al., 16 1988; Misund et al., 1997; Huse et al., 2012). However, in recent years herring in the western 17 Atlantic seem to have changed their vertical distribution. Fishermen and scientists have 18 reported that herring are staying closer to bottom than usual during certain periods of the year.

19 In several areas fish were not coming off bottom and inaccessible to purse seine gear (Power et 20 al., 2011).

\subsubsection{Life history}

Herring stocks exhibit temporal and geographic differences in life-history traits. Populations are described as spring, winter, summer, or autumn spawners, although more than one type can occur in a stock. Spring and summer spawners are more prevalent in northern waters, autumn and winter spawners in the south, and a mixture in central regions (Melvin et al., 2009). In the Gulf of St Lawrence the two types use the same spawning habitat, although spring spawners generally spawn in more shallow inshore waters. Hatching time takes from 814 days and depends on water temperature.

31 Herring mature between ages 2 and 6, with the majority maturing at 3-4 years. Northern 32 stocks, like NSSH and Newfoundland herring, become mature later at ages of 3-6 years and 33 have a maximum life span of over 20 years. Stocks at the southern extent of their range have 34 shorter maximum life-span of 12-14 years, especially in recent years, and mature younger. 
1 Gulf of Maine herring reach maturity at 23-25 cm aged 2-4 years, while those off the east coast

2 of Newfoundland take 3-6 years to reach a similar size and mature (Melvin and Stephenson,

3 2009; Wheeler et al., 2009). Variations in age at maturity are believed to reflect variations in

4 body growth, stock abundance, and environmental change (Melvin and Stephenson, 2007).

5 Length specific fecundity has been reported for most populations (e.g., Zijlstra, 1973; Kelly

6 and Stevenson, 1985; Óskarsson et al., 2002). The reproductive strategy of a spawning

7 population also has an influence on how fecund the fish will become (van Damme, 2009). In

8 general autumn spawners produce smaller and more numerous eggs than winter/spring

9 spawners. Stock density and environmental factors, which affect feeding and body condition,

10 may also affect fecundity (Flinkman et al., 1998).

11 Generally, populations in colder water grow more slowly and live longer than those in warmer water (Brunel and Dickey-Collas, 2010). Individuals of strong year classes tend to be smaller

13 when maturity is reached (Toresen, 1990; Melvin and Stephenson, 2007). The reduced growth 14 rate of large cohorts is less pronounced once they become adults. For the NSSH growth rate 15 is thought to depend on their distribution. If young NSSH migrate into the Norwegian fjords, 16 reduced growth rate is caused by density dependence, while if they move into the Barents Sea 17 it occurs because of lower temperatures. Evidence of density dependent herring growth are also 18 found in the Icelandic summer-spawning herring (Óskarsson, 2008), while density dependent growth is not observed in the Celtic Sea (Molloy, 1984). In the NW Atlantic, densitydependent growth also occurs in stocks from Georges Bank (Melvin and Stephenson, 2007),

21 Gulf of Maine (Anthony and Fogarty, 1985), southwest Nova Scotia (Sinclair et al., 1982) 22 and possibly the east coast of Newfoundland (Moores and Winters, 1984). Length- and 23 weight-at-age in many stocks have shown decadal declines, which have been hypothesized 24 to be environmentally driven (Wheeler et al., 2009; Power et al., 2010; Brunel and Dickey25 Collas, 2010).

26

Recruitment in herring stocks as in most fis stocks has been linked to the classical recruitment hypothesis as outlined by Houde (2008). Larval survival and subsequent year class strength in NSSH is enhanced by early hatching time (Husebø et al., 2009), reduced cannibalism (Dalpadado et at., 2000), rapid displacement of larvae to the Barents Sea nursery area (Vikeb $\varnothing$ et al., 2010), and higher temperature in the Barents Sea (Toresen and Østvedt, 2000). In the Western Atlantic, declines in predator abundance and environmental conditions, decreased fishing effort, and increased spawning biomass have generated strong year classes (Overholtz et al., 2004; Melvin et al., 2009; Wheeler et al., 2009). Temperature changes may also have 
1 influenced the relative reproductive successes of the different spawning strategies (Melvin et 2 al., 2009).

3 Recruitment patterns can be local, regional, or sometimes synchronous on an oceanic scale, 4 suggesting wide scale climatic influence. It is not uncommon for herring stocks to have several 5 years of poor (i.e., below average) recruitment to be followed by 1 or 2 years of strong 6 recruitment when optimum conditions are met: however, systematic directional changes have also been observed in some stocks (Payne et al. 2009). For example, Gulf of St. Lawrence spring spawners have had more than a decade of below average recruitment while the fall spawners have had average or above recruitment for the same period (LeBlanc et al., 2010). Instances of large year classes and thus high recruitment success have also been reported in the NE Atlantic herring stocks (Óskarsson and Taggart, 2010; Toresen and Østvedt, 2010). In the NW Atlantic, regional and broad synchronous recruitment pattern have been reported in Scotia-Fundy herring by Óskarsson, (2005), Georges Bank by Melvin et al. (1996), in the Gulf of St Lawrence by Leblanc et al (2010) and off the east coast of Newfoundland by Wheeler et al. (2010).

\subsection{Mackerel}

\subsubsection{Geographic distribution}

Mackerel are widespread in the NE Atlantic, from Morocco to Norway, with observations the Mediterranean Sea, Skagerrak, Kattegat and westernmost Baltic Sea. Periodically in the summer mackerel can also be found in coastal areas around Iceland (Astthorsson et al., 2012). In the NW Atlantic mackerel is found from the Gulf of Maine to the Gulf of St Lawrence. The Atlantic mackerel have traditionally been divided into five spawning components, two in the west and three in the east. However, the population structures on either side of the Atlantic are possibly better described as dynamic clines, rather than as connected entities (Jansen et al., 2013, Jansen and Gislason, 2013).

\subsubsection{Spawning habitats and migrations}

NEAM spawn along the shelf break from Spanish and Portuguese waters in March to the west of Scotland and in the North Sea in June. The highest spawning intensity is off Ireland (ICES, 2010c), in the same area as blue whiting but later in the year. Previously, spawning in the North Sea likely supported a large part of the NEAM stock; this changed after the collapse in the late 1960s-70s (Jansen et al., 2012b, Jansen, 2013). 
1 Spawning activity of NEAM has progressively moved north during the period 1977-2010

2 with a shift of $39 \mathrm{~km}$ for every degree Celcius of warming (Hughes et al., submitted). In warm

3 years, mackerel in the North Sea spawn earlier than in cold years (Jansen and Gislason, 2011).

4 As for the southern and western spawning components, there is substantial interannual

5 variation but no simple relationship with water temperature seems to exist (Punzon and

6 Villamor, 2009).

7 Stocks on both sides of the Atlantic perform extensive annual migrations between spawning

8 and feeding grounds. In the NE Atlantic the post-spawning migration disperses the mackerel

9 into adjacent shelf waters and northwards, where feeding takes place (Uriarte and Lucio, 1996;

10 Belikov et al., 1998; Uriarte et al., 2001). While NEAM also migrate into open waters in the

11 Nordic Seas to feed during summer, there is no evidence of such off-shelf feeding in

12 NWAM. In late summer and early autumn the pre-spawning migration begins. This migration

13 includes shorter or longer pauses, which sometimes are referred to as overwintering, and

14 ultimately ends at the spawning areas. A deeper understanding of the main drivers of the

15 highly dynamic mackerel distribution patterns remains elusive.

16 Free floating eggs of NEAM mackerel occur deeper early in the spawning season when there is 17 little thermal stratification (Röpke, 1989; Coombs et al., 2001). As stratification develops, eggs 18 become progressively more restricted to the surface layers (Coombs et al., 2001). In spawning areas along coasts of the USA and Canada as well as the North Sea and Kattegat/Skagerrak, stratification is already developed when spawning occurs. In these systems

21 high abundances of eggs are found above the thermocline (Nilsonn, 1914; Sette, 1943; 22 Myrberget, 1965; Iversen, 1977; Ware and Lambert, 1985). Transport of eggs and 23 larvae to known nursery areas has been examined employing 24 individual-based models. These studies suggest that passive transport in the short egg/larval 25 phase is insufficient to bring larvae to the known nursery grounds (Bartsch and Coombs, 2004; 26 Bartsch et al., 2004; Bartsch, 2005). Hence it seems that active migration of juveniles is 27 required to reach the nursery grounds.

28 Environmental conditions impact post- and pre-spawning migration patterns and the spatial 29 distribution of adult NEAM and NWAM. In warm years an eastward post 30 spawning migration occurs earlier from the North Sea spawning area (Jansen and 31 Gislason, 2011). Mackerel feeding distribution in the Nordic Seas (up to $76{ }^{\circ} \mathrm{N}$ North of 32 Norway in the north-east, beyond Iceland in the west) is positively correlated with 33 temperature, which is influenced by the Atlantic inflow, indicating warmer temperature 
1 preferences compared to herring and blue whiting (Utne et al., 2012b). Thus warming of the

2 Nordic Seas has enlarged the potential habitat for NEAM. The northwestwards expansion

3 during spawning and summer feeding migrations is confirmed by catch and survey data from

4 recent years, although the observed change could also be a consequence of changes in food

5 availability and increased stock size. The pre-spawning migration from the northern feeding

6 grounds occur through the northern North Sea and the areas to the west of Scotland (Walsh

7 et al., 1995; Reid et al., 1997) where over-wintering occurs.

8 Fisheries data show that the changes in the timing of the pre-spawning migration of the 9 westernspawning component of the NEAM have been dramatic over the last 30 years. The migration passed through the west of Scotland area in September 1975. By the late 1990s it 11 passed through this area in January/February. This appears to have remained fairly consistent up to 2005 (Walsh and Martin, 1986; Reid, et al., 2003; 2006), but subsequently changed. In 13 2006-2007 the migration was later (ICES, 2007), while commercial catch and survey data from 2008-2010 suggested that either the stock initiated the southwestern migration earlier, or that the pre-spawning migration took a more westerly route. Temperature clearly plays a role in the modification of the pre-spawning migration. The distribution and timing of the fisheries that follow the mackerel are correlated with sea-surface temperature (Jansen et al., 2012a). Local shoals appear to be constrained by temperature before the onset of migration towards the wintering and spawning areas (Reid et al., 2001b) with temperature also influencing migration path and speed (Walsh et al., 1995; Reid et al., 1997). Similar to herring, body size also affects migration patterns, with larger individuals migrating farthest (Holst and Iversen, 1992; Nøttestad et al., 1999). Furthermore, at the eastern end of the feeding migration large mackerel arrive earlier and leave later than small mackerel (Jansen and Gislason, 2011).

In the NW Atlantic, the $7^{\circ} \mathrm{C}$ isotherm was long seen as forming a temperature barrier to the northern advance of mackerel along the US east coast (Goode, 1884; Sette, 1950; Bigelow and Schroeder, 1953). Captive mackerel increase their swimming speed in water below $7{ }^{\circ} \mathrm{C}$ and

27 this has been interpreted as a behavioural response to low temperature (Olla et al., 1975; 28 1976). However, field observations have shown that mackerel from the southern component of 29 the NWAM avoid waters below $5{ }^{\circ} \mathrm{C}$, most individuals being found in waters above $6{ }^{\circ} \mathrm{C}$. 30 Furthermore, the spring distribution seems to be more northern and in-shore in warmer years 31 (Overholtz et al., 1991). However, in 1990 mackerel from the northern component migrated 32 into Cabot Strait where the water temperature was approx. $4{ }^{\circ} \mathrm{C}$ in order to reach their 33 spawning grounds (D'Amours and Castonguay, 1992). These authors argued that this 
1 demonstrated how thermal preferences can become subordinate to reproductive requirements,

2 a point supported by the fact that this stock always enters the Cabot Strait around the same 3 date (Anon., 1896; Castonguay and Gilbert, 1995).

4 On a smaller scale, local distribution also can be affected by temperature. For example, local mackerel abundance has been observed to coincide with wind-induced warming of coastal water on a time-scale of days in a coastal area in Northern Canada (Castonguay et al., 1992).

\subsubsection{Life history}

Mackerel reach maturity at the age of 2-3 years and can grow to over $60 \mathrm{~cm}$ length and 20 years in age (Lockwood, 1988). We know of no studies linking variation in fecundity or reproductive potential to environmental factors.

The growth rate increases from hatching until young mackerel measure 40-100 mm, by which time they grow at up to $2.5 \mathrm{~mm} \mathrm{day}^{-1}$ under optimal conditions (Ware and Lambert, 1985; Bartsch, 2002). Larval growth and development is faster at higher temperatures (Mendiola et al., 2007; Robert et al., 2009). Growth rate, especially in smaller fish, is density- dependent. The mean length of age-1 fish is negatively correlated with stock biomass in NEAM (Agnalt, 1989; Dawson, 1991) and NWAM (MacKay, 1973; Overholtz, 1989; Neja, 1995; Ringuette et al., 2002). Adult growth rates may vary spatially, although observed patterns are confounded by size-dependent migration in which large fish leave spawning and feeding areas earlier (Dawson, 1986; Eltink, 1987; Nøttestad et al., 1999; Villamor et al., 2004; Jansen and Gislason, 2011).

In the NW Atlantic, recruitment from the northern spawning area of NWAM depends on the production of the nauplii of copepod species that make up the larval diet (Robert et al., 2007;

Castonguay et al., 2008). Recruitment of NEA mackerel has been surprisingly stable for the last three decades when compared to other pelagic species, such as blue whiting and herring, and a significant part of the variability has been explained by an index of wind induced turbulence (Borja et al., 2002).

\subsection{Capelin}

\subsubsection{Geographic distribution}

Capelin is a cold-water species inhabiting arctic and subarctic waters in the North Atlantic and North Pacific. In the North Atlantic, several stocks are found in the Barents Sea, around Iceland, and in the Newfoundland and Labrador waters (Vilhjálmsson, 1994). 


\subsubsection{Spawning habitats and migrations}

Capelin are demersal spawners that deposit their eggs on fine gravel (Vilhjálmsson, 1994). Spawning locations are determined by temperature (Nakashima and Wheeler, 2002) or by bottom substrate with temperature as a secondary factor (Carscadden et al., 1989). The larvae drift to nursery grounds whose locations vary according to changes in the coastal currents. Icelandic capelin larvae drift mainly to the northwest and northeast Icelandic shelf and to a varying extent to the East Greenland plateau (Vilhjálmsson, 1994). The effect of this variation on larval survival is unknown. For northwest Atlantic capelin, the extent of larval drift from the coast to the shelf may (Taggart and Leggett, 1987) or may not (Dalley et al., 2002) have an important role for recruitment.

Before 2001, the Icelandic capelin migrated north to the Iceland Sea (to at least $72^{\circ} \mathrm{N}$ ) for summer feeding (Vilhjálmsson, 2002), while since then summer feeding is believed to have taken place further west on the Greenland plateau (Pálsson et al., 2008). Similar patterns have been observed for juveniles, implying displacement of the distribution to the west and south. Both of these changes were linked to likely increased temperature in the Iceland Sea during this period possibly because of observations of increased inflow of warm Atlantic water into Icelandic waters. Barents Sea capelin also undertake extensive feeding migrations northwards into the Barents Sea and the position of the feeding areas varies with hydrographic conditions such that in warmer years the distribution of capelin extends further north- and eastwards (Gjøsæter, 1998). The distribution is thus broader in warmer years (Orlova et al., 2010). The NW Atlantic capelin stocks undertake similar extensive feeding migrations. In the early 1990s the stocks had a generally more southerly distribution in both the west (Scotian Shelf) and the east (Flemish Cap; Carscadden et al., 2001). These changes were linked to colder seawater as a consequence of a positive NAO. However, these changes persisted after the temperature returned to 'normal' again, which might have been caused by changes in prey quality in offshore feeding areas (DFO, 2011).

Sea ice formation probably affects the capelin feeding distribution. During summer capelin often feed near the receding ice edges, which are areas rich in phytoplankton and subsequently zooplankton (Gjøsæter, 1998).

Capelin undertake diel vertical migrations following their prey, aggregating at greater depths during the day (Mowbray, 2002). In the NW Atlantic diel vertical migration is apparently length dependent where small capelin $(<12 \mathrm{~cm})$ migrate between 0 and $100 \mathrm{~m}$ together with 
1 smaller zooplankton preys (copepods) and large capelin $(>12 \mathrm{~cm})$ down to $300 \mathrm{~m}$ together

2 with large zooplankton prey (amphipods and euphausiids; Davoren et al., 2008). The feeding

3 preferences of Barents Sea and Icelandic capelin suggest similar diel migrations in the NE

4 Atlantic.

5

6

7

\subsubsection{Life history}

Spawning mainly occurs in March-April in the Barents Sea and around Iceland and in MayJuly in the NW Atlantic stocks (Vilhjálmsson, 1994; Nakashima and Wheeler, 2002). Barents Sea and Icelandic capelin are deep-water spawners while most of the capelin populations in the NW Atlantic are principally beach spawners although some spawning occurs in adjacent deeper waters.

Capelin first reaches maturity at age 2-4 (majority 3 yrs). Only a small proportion survives spawning, and few females spawn a second time (Carscadden and Vilhjálmsson, 2002). Maximum length is $20 \mathrm{~cm}$ with males larger than females. Variability in growth affects age-atmaturity of the Icelandic capelin (2 to 4 yrs; Vilhjálmsson, 1994).

Age- and length-specific fecundity of the capelin stocks is highest for NW Atlantic beachspawners and lowest for the Barents Sea bottom spawners and Icelandic stocks (Jóhannsdóttir and Vilhjálmsson, 1999). Fecundity is density-dependent in Barents Sea capelin (Tereshchenko, 2002). We know of no study linking variations in fecundity or reproductive potential to environmental factors.

The growth rate of Barents Sea capelin is positively related to zooplankton abundance (Gjøsæter et al., 2002) and temperature, and varies with location, probably driven by spatial patterns of temperature and/or food availability (Gjøsæter, 1998). The fat content of Barents Sea capelin has been related to the NAO (North Atlantic Oscillation) and stock size (Orlova et al., 2010). The mean weight-at-age of Icelandic capelin is higher during warmer periods, which are characterized by higher zooplankton abundance (Astthorsson and Gislason, 1998).

Being short-lived, capelin population dynamics are driven by recruitment, which can lead to large and rapid changes in stock biomass. Despite the importance of recruitment, the causes of its variability are poorly understood. Although stock and 0-group size are related for Icelandic capelin, no stock-recruitment (age 1) relationship has been found. This points towards the importance of environmental and/or ecological factors during the first winter for determining recruitment success (Jóhannsdóttir and Vilhjálmsson, 1999). In contrast, acoustic surveys showed that the abundances of age 1 and age 2 fish one year later (i.e. a single cohort) were 
1 strongly related (Vilhjálmsson, 2002). Recruitment in Newfoundland capelin was found to be

2 positively related to the frequency of onshore winds during larval emergence (Carscadden et al., 2000). Capelin recruitment in the Barents Sea depends on herring and cod predation, and is positively correlated to temperature (Hjermann et al., 2010).

\section{$2.4 \quad$ Blue whiting}

\subsubsection{Geographic distribution}

The major biomass of blue whiting inhabits the eastern half of the North Atlantic basin and exhibits a broad distribution in this region. Smaller stocks of this species exist in the NW Atlantic and Mediterranean Sea (Bailey, 1982). The NW Atlantic stocks are not commercially exploited with little known about their spatial and temporal dynamics. For this reason, we focus exclusively on the NE Atlantic populations where information is more readily available. The NE Atlantic latitudinal distribution ranges from the Iberian Peninsula and the Mediterranean in the south to the Barents Sea in the north while they range longitudinally from the North Sea to the mid-Atlantic ridge.

\subsubsection{Spawning habitats and migrations}

Blue whiting spawn in spring along the eastern margin of the North Atlantic basin in the water column at around 500-700 m. The majority of spawning takes place between Porcupine Bank in the south and the Hebridean shelf in the north, although significant spawning aggregations have also been observed (intermittently) across the Rockall Trough, on Rockall Bank and Hatton Bank (Hátún et al., 2009b). Larvae as an indicator of spawning have also been observed along the continental shelf-edge in the Bay of Biscay (Arbault and LacroixBoutin, 1969), around the Iberian Peninsula (Ibaibarriaga et al., 2007) as well as off the coast of Norway and Iceland (Bailey, 1982). Numerical particle tracking studies focused on the drift of eggs have examined the potential for separation into northern (Hebridean shelf and Norwegian Sea) and southern (Porcupine Bank and Bay of Biscay) stocks (Svendsen et al., 1996; Bartsch and Coombs, 1997; Skogen et al., 1999). Environmental barriers to gene flow within the centre of the range have been identified, with the suggestion of up to four stock components (Was et al., 2008).

The spatial distribution of the spawning populations has been shown to be influenced by the dynamics of the subpolar gyre (Hátún et al., 2009b). Spawning appears to take place preferentially between the 9 and $10{ }^{\circ} \mathrm{C}$ isotherms, the locations of which are influenced by the 
1 dynamics of the subpolar gyre. In years when the gyre is weak and the Rockall Plateau and 2 trough are flooded with warm, saline water from the south, spawning is more widespread, 3 extending in the north towards the Hebridean shelf and possibly also expanding onto Rockall 4 Bank. Conversely, in years when the gyre is strong, colder, fresher gyre-water pushes the 5 isotherms southwards and eastwards, resulting in spawning limited to the Porcupine Bank. 6 These conclusions appear to be relatively robust, and are confirmed by historic observations 7 of blue whiting larvae, acoustic survey data and fisheries catch statistics. However, it is not 8 clear how they relate to the dynamics of the putative northerly and southerly populations, particularly as observations of the spawning distribution south of Porcupine Bank are very limited.

The eggs, larvae and juveniles drift both northwards and southwards after spawning, depending on where they were released in relation to the -separation linell (Bartsch and Coombs, 1997; Skogen et al., 1999). Observational studies have also confirmed a significant impact of environmental variables upon larval dispersal and retention in the Porcupine Bank area (Kloppmann et al., 2001). Unfortunately, there are no modern studies that cover the period of strong year-classes associated with changes in the sub-polar gyre after 1995: it is therefore not known what these oceanographic changes have meant for larval dispersal and recruitment. Studies covering more recent years are therefore required to understand the implications of the observed recruitment changes.

It is believed that the major nursery grounds are along the Norwegian coast (possibly in fjords), to the south west of Iceland, and along the continental shelf-edge south of Porcupine Bank (Bailey, 1982). More recent work has highlighted the presence of small immature blue whiting in the Barents Sea: their abundance in this region however, appears to be modulated by both population dynamics and hydrographic conditions, and it is not clear whether this is a regularly inhabited nursery ground (Heino et al., 2008). There are also nursery grounds in the south. In the Bay of Biscay and Celtic Sea in early winter, 0-group blue whiting have been found primarily along the shelf edge, with no relationship between spatial location and bottom temperature or salinity (Persohn et al., 2009).

29 The post-spawning adults (from the northerly population) return northwards to the feeding grounds in the Nordic Seas. The route taken by this post-spawning migration has been shown 31 to be influenced by the dynamics of the subpolar gyre (Hátún et al., 2009a). In years where the gyre is weak and has retreated westwards, the migration route passes to the west of the Faroe 33 Islands, whereas in years when the gyre is strong, the route passes through the Faroe- 
1 Shetland Channel. It is thought that this migration reflects, at least partially, the differences in

2 the spawning distribution also induced by the gyre (i.e. a more westerly spawning distribution 3 when gyre is weak (Hátún et al., 2009b)) and therefore the starting point for this particular 4 migration.

5 Blue whiting perform diel vertical migrations (Johnsen and Godø, 2007). During summer

6 feeding in the Norwegian Sea the diel migration is about $65 \mathrm{~m}$ between a median day depth of $7325 \mathrm{~m}$ and a median night depth of 260m (Huse et al., 2012). The adults from the northerly 8 population feed in the Nordic Seas during summer (Utne et al., 2012b), with large aggregations 9 being found near the entrance to the Barents Sea while those from the southerly population are found on Bay of Biscay the shelf edge in late spring. Little is known about the overwintering 11 behaviour of the fish, or pre-spawning migrations.

12

13

\subsubsection{Life history}

Spawning starts in January-February in the southern part of the blue withing distribution and gets progressively later with increasing latitude. The peak season is in March and April, corresponding to the productive period at the main sites around Porcupine Bank and the Irish and Scottish west coasts. Spawning typically starts at 2-4 years, when the fish are between 19 and $24 \mathrm{~cm}$ in length (ICES, 2007).

Larvae occur mostly in the upper $60 \mathrm{~m}$ of the water column (Coombs et al., 1981). Several studies have examined the linkages between the environment and larval growth rates. Increased larval growth has been linked to the intrusion of warm, saline tongues of water along the continental shelf edge (Bailey and Heath, 2001) and larval condition to turbulence and wind mixing events (Hillgruber, 2000; Kloppmann et al., 2002). However, again there are no published post-1995 studies that examined the impacts of the changes that occurred during this time. In the Bay of Biscay, 0-group size in late autumn is negatively related to density but unrelated to mean summer water temperatures, suggesting density-dependent juvenile growth in this area (Persohn, 2009). Adults captured in the southern part of the range have faster growth rates as larvae and juveniles than those from the northern part (Brophy and King, 2007).

The population dynamics of blue whiting has been dominated in recent years by large swings in recruitment. Recruitment of the Northern population increased suddently from 1995 to 2004 to four to ten times that of the previous decade before suddenly returning to levels comparable to, or even below, pre-1995 levels (Payne et al., 2012). By contrast, the putative 
1 southern population showed low recruitment between 2001 and 2005 (Persohn et al., 2009).

2 The sudden increase in northern population recruitment from 1995 onwards occurred 3 synchronously with large changes in the physical and biological environment in the North 4 Atlantic. The sub-polar gyre collapsed and retreated rapidly westwards during this time, 5 allowing the influx of warmer, more saline water from the south into the area to the west of 6 Ireland and Scotland, together with large changes in the phytoplankton and zooplankton communities (Hátún et al., 2005; 2009a). The temporal co-occurence between these phenomena has led several authors to propose a causal linkage (Hátún et al., 2009b; Payne et al., 2012): however, the termination of a string of strong year-classes from 2005 onwards is not fully explained by the dynamics of the sub-polar gyre, and there is no significant correlation between the state of the gyre and year-class strength (Payne et al., 2012). Furthermore, the mechanisms driving a potential linkage between the sub-polar gyre and the recruitment remain unclear, with two candidate mechanisms being identified. One hypothesis suggests that large mackerel stocks in the same region may potentially exert a high (and controlling) predation upon pre-recruit blue whiting: changes in the spatial and temporal overlap between the two species, possibly modulated by the dynamics of the sub-polar gyre, can therefore influence the survival rates of blue whiting and thus recruitment. Alternatively, gyre-driven variations in the physical and biological environment may change the amount, type, and availability of food for larvae and juveniles, impacting growth and availability. It is not currently possible to distinguish between these two hypotheses (Payne et al., 2012).

\subsection{Horse mackerel}

\subsubsection{Geographic distribution}

Horse mackerel is only found in the NE Atlantic, from the southern Norwegian coast to Mauritania and across the whole Mediterranean Sea, overlapping widely with mackerel and blue whiting. Three horse mackerel stocks are currently identified, one in the southern North

30 Sea, one stretching from the Norwegian Sea to the Cantabrian Sea (Western stock) and the 31 third along the Atlantic coast of the Iberian peninsula (Southern stock) (ICES, 2010a).

\subsubsection{Spawning habitats and migrations}

Spawning takes place in the water column on the shelf edge and adjacent continental shelf. After hatching eggs drift to the nursery grounds. In a simulation study with a hydrodynamic model for the southern North Sea, Peck et al. (2009) found that horse mackerel larvae had a 
1 short drift phase (9-10 days) and a small drift distance though it varied between years. The

2 short period is due to high temperatures during the summer leading to rapid development of

3 the embryo.

4 Horse mackerel migrate between spawning, feeding and overwintering grounds (Abaunza et

5 al., 2003). Migrations of adults from the spawning grounds in the Bay of Biscay and Celtic

6 Sea to the feeding grounds in the Norwegian Sea might be related to the transport of Atlantic

7 water into the North Sea (Iversen et al., 2002). It is plausible that horse mackerel also follow

8 these productive waters to the Norwegian Sea and further north (Iversen et al., 2002) in a

9 similar fashion to mackerel (Langøy et al., 2012); their migration might be assisted in years of

10 high northerly advection of waters along the western edge of the European shelf (Reid et al.,

11 2001). As with herring and mackerel, the migration pattern of horse mackerel is also size

12 dependent.

13 Migration of horse mackerel from the feeding grounds in the Norwegian Sea to areas further

14 south and from the southern North Sea into the Eastern English Channel is thought to be

15 triggered by temperatures falling below $10{ }^{\circ} \mathrm{C}$ (see review in Abaunza et al., 2003).

16 Vertical distribution of horse mackerel eggs and larvae shows the increased movement of 17 early life stages towards the surface (Coombs et al., 1979; Southward and Barrett, 1983; 18 Coombs et al., 1996). In the Celtic Sea and Bay of Biscay eggs and larvae occur 19 predominantly above the thermocline, situated at around $80 \mathrm{~m}$ depth. When the seasonal 20 thermocline develops there is a progressive reduction in the mean depth of both eggs and 21 larvae. Adult horse mackerel can occupy a large range of depths in the water column, with a 22 strong demersal behaviour during daylight hours (Lloris and Moreno, 1995).

\subsubsection{Life history}

Horse mackerel is a batch spawner with an extended spawning season (up to 8 months) that varies between regions and years (Abaunza et al., 2003). The highest incidence of spawning is from May to July at the shelf-edge and over adjacent shelf region on the Celtic platform and 29 Biscay (Eaton, 1989; Franco et al., 1993). In the southern Bay of Biscay eggs and larvae have 30 been found year-round (d'Elbée et al., 2009; Franco et al., 2009).

31 Fecundity in horse mackerel is length- and area dependent with lowest fecundity in the North 32 Sea (Abaunza et al., 2008). Size at first maturity increases with latitude in a similar manner 33 as length (Abaunza et al., 2008). We know of no studies linking variation in fecundity or 34 reproductive potential directly to environmental factors. 
1 Maximum body length is between 40 and $50 \mathrm{~cm}$ (Abaunza et al., 2003), maximum age 40 2 years and females reach maturity between 2 and 4 years (Abaunza et al., 2003). Variability in 3 individual growth of horse mackerel is thought to depend on food availability and cohort strength (Abaunza et al., 2003) showing increased length-at-age with latitude, which for the western stock is interpreted as size-dependent migration (Abaunza et al., 2008). Growth varies seasonally; it is more rapid between August and December (Macer, 1977). Horse mackerel can produce extremely strong year classes, with the well-documented 1982 yearclass providing the bulk of catches for over ten years (De Oliveira et al., 2010). A second large, though not as extreme, year class appeared in 2002. However, little is known about the factors controlling recruitment. Santos et al. (2001) found a negative relationship between upwelling events and horse mackerel recruitment in Portuguese waters which could be caused by increased offshore larvae transport and consequent mortality. In complete contrast, Lavín et al. (2007) concluded that years with cooler coastal SST (an indication of upwelling and less stormy weather) during spring and summer supported strong recruitment.

\subsection{Knowledge gaps}

Our review highlighted the wealth of currently available knowledge on the distribution and life history of small pelagics in the North Atlantic but also allowed us to identify important knowledge gaps (Table 1).

Herring is probably the most studied species among those considered, which is not surprising given its commercial importance. However, some aspects of its biology still need further studies, such as the reasons for the frequent observed changes in migration patterns and the impacts of the oceanographic environment on recruitment success.

25 Temperature has been shown to have a great effect on mackerel distribution and phenology in 26 some parts of the life cycle. However, it has been difficult to find simple causal relationships with any specific parameter, (e.g. prey availability, spawning conditions, temperature etc.). Clearly, more research is needed relating migration and production to variation in environment,

29 regime shifts/large scale circulation patterns and stock size. It is likely that variation of the 30 subpolar gyre, which has been shown to affect the northeastern pelagic food web (Hátún et al., 31 2009a), also affects mackerel migrations and subsequently recruitment. Clarifying the role of 32 stock structure is fundamental for understanding the dynamics of mackerel stocks and for 33 evaluating how they have and will respond to changes in the environment and the fisheries. 34 Finally, doubt has beeen cast on historical and current estimates of NE Atlantic mackerel stock 
1 size (ICES, 2012; Simmonds et al., 2010). This issue needs to be addressed adequately to

2 ensure research results concerning stock dynamics are reliable.

3 As capelin is a short-lived species, adult stock sizes reflect the recruitment success of only one

4 to two year classes. The factors causing these recruitment variations are, however, poorly

5 known and require further study. Climate change is likely to affect the distribution and life

6 history of the capelin stocks but answers to questions such as how and what will be the

7 consequences are uncertain.

8 The stock structure of blue whiting is currently strongly debated. A number of older

9 published studies exist but unfortunately, there are no modern studies that cover the period of

10 strong year-classes associated with changes in the sub-polar gyre after 1995: it is therefore not

11 known what these oceanographic changes have meant for larval dispersion and (meta-)

12 population dynamics in general. Further, few studies exist for the southern part or possibly

13 southern population of blue whiting which would link recruitment, survival and growth to

14 environmental factors. Clearly more work on the NE Atlantic blue whiting and in particular in

15 its southern distribution area is required.

16 The impacts of environmental conditions on horse mackerel spatial patterns and life history

17 parameters have been very poorly studied; much remains to be done.

18

19

21

22

24

25

\section{Distribution and life history of large pelagic fish species in the North Atlantic}

\subsection{Albacore and bluefin tuna}

\subsubsection{Geographic distribution}

Albacore is a highly migratory species with no evidence of any subpopulation structure within the north Atlantic basin (Arrizabalaga et al., 2004; Montes et al., 2012; Albaina et al., 2013). Albacore inhabit the epi- and mesopelagic layer with a general geographical distribution from the tropics to about $45^{\circ} \mathrm{N}$ roughly limited by a SST of $15-21^{\circ} \mathrm{C}$ (Sagarminaga and Arrizabalaga, 2010). Their high metabolic rates necessitate sufficient oxygen concentrations; the lower tolerance limit is around $3.7 \mathrm{~mL} \mathrm{~L}^{-1}$ (Graham et al., 1989) and below $1.23 \mathrm{~mL} \mathrm{~L}^{-1}$ oxygen concentrations become lethal (Sharp, 1978).

The geographic distribution of bluefin tuna is substantially wider than for albacore; it ranges from NW Africa to central/northern Norway in the east, including the Mediterranean Sea and formerly also the Black Sea. In the West Atlantic, the known latitudinal range is historically 
1 broader, extending from northern Argentina through the Caribbean to the north coast of

2 Newfoundland (Mather et al., 1995; Rooker et al., 2007). Thermoregulation using a specialized

3 vascular counter current heat exchange system called the -rete mirabilell allows bluefin tuna to

4 extend their accessible habitat to colder waters. The range of surface temperatures experienced

5 by bluefin tuna while in northern waters (e.g., near Iceland, North Sea, Norwegian Sea; Gulf of

6 St. Lawrence, north coast of Newfoundland) during summer are ca. 3-20 ${ }^{\circ} \mathrm{C}$ (Mather et al.,

7 1995; Tiews, 1978; MacKenzie and Myers, 2007; Galuardi et al., 2010). Historically, bluefin

8 tuna inhabited the North Sea during spring and summer, exciting the system when

9 temperatures fell below $12{ }^{\circ} \mathrm{C}$ (Tiews, 1978). There are presently two managed stocks of

10 bluefin tuna in the north Atlantic, which are delimited by an east-west boundary through the

11 north Atlantic at $45^{\circ} \mathrm{W}$. The boundary was established before traditional and data-storage

12 tagging studies revealed trans-Atlantic migrations in both NE and NW directions (Mather et al.

13 1995, Block et al. 2001, Block et al. 2005; Galuardi et al., 2010). The large-scale geographic

14 distribution of bluefin tuna in the Atlantic has changed during the past 60 years. Some areas

15 for example off northern Brazil, North Sea and Norwegian Sea which formerly supported

16 fisheries no longer do with so occasional sightings occurring (Mather et al., 1995; MacKenzie

17 and Myers, 2007; Fromentin, 2009; Worm and Tittensor, 2011). The reasons for these changes

18 are not clear. In some of the eastern areas there have been major declines in the abundance of

19 the key forage fish species. For example, both the NSSH and the North Sea herring

20 populations collapsed in the 1960 s and 1970s respectively. This reduction may be one

21 mechanism contributing to an overall reduction in the range of bluefin tuna in the north

22 Atlantic (Worm and Tittensor, 2011). Noteably, there isno apparent range reduction in the

23 western Atlantic based on studies utilizing electronic tags (e.g., Galuardi et al., 2010) and

24 recent aerial surveillance (Lutcavage et al., unpubl). Integration of information from catch

25 trends, electronic tagging and life history modelling suggests that complex interactions

26 between bluefin adult population size (density-dependent effects), exploitation, prey

27 abundances and oceanographic conditions are at play for shaping bluefin spatial distribution

28 and range (Schick et al., 2004; Schick and Lutcavage, 2009). In the Pacific bluefin tuna

29 migrate to the west coast of North America from the eastern Pacific in years when prey

30 abundance is high. However, in the NE Atlantic, the herring biomass in both areas formerly

31 occupied seasonally by bluefin tuna has now recovered, yet the bluefin tuna have not

32 reappeared. In contrast, in the western Atlantic, the spatial distribution patterns of adults and

33 juveniles appear to be shifting northward and offshore (Golet et al., unpublished results), most 
1 likely in response to changes in availability of prey and physical forcing (Golet et al., 2007;

2 2011). Since 2009, individuals as small as $115 \mathrm{~cm}$ are occurring as far north as the Scotian

3 shelf and Gulf of St. Lawrence, and in 2010 and 2011, giant bluefin were observed and caught

4 in Canadian regions north of $55^{\circ} \mathrm{N}$, where they have not been previously reported.

5

6

\subsubsection{Spawning habitats and migrations}

Albacore spawning grounds have been found in waters offshore Venezuela, the Sargasso Sea (Le Gall, 1974; Nishikawa et al., 1985) and in the Gulf of Mexico (Richards, 1969; 1984). Juveniles seem to spend the winter in subtropical areas. In spring, one year old immatures ( $40 \mathrm{~cm}$ ) migrate to feeding grounds in the NE Atlantic, where they are caught by fisheries. They are found near the Azores at $38^{\circ} \mathrm{N}$ latitude in May and spread between southwest of Ireland and the Bay of Biscay 1-2 months later (Ortiz de Zárate and Cort, 1998). In late October albacore start migrating back to the mid Atlantic following a route south of Portugal, the Canary Islands and the Azores (Arrizabalaga, 2003). The feeding migration is linked to the seasonal SST warming and cooling, albacore tuna following a preferential SST window between 16 and $18{ }^{\circ} \mathrm{C}$ (Sagarminaga and Arrizabalaga, 2010). This suggests that temperature is a strong environmental factor restricting the habitat of North Atlantic albacore juveniles. In fact, Dufour et al. (2010) showed that the latitude of the young albacore distribution in the offshore feeding area off the Bay of Biscay was correlated with the latitude of the $17{ }^{\circ} \mathrm{C}$ isotherm, and that during warmer years albacore migrated earlier to the feeding grounds. Some albacore are also able to enter into the Bay of Biscay, which has significantly warmer waters (referred to as -inner clusterll in Sagarminaga and Arrizabalaga, 2010). Mature adult albacore ( $>5$ years, $>90 \mathrm{~cm}$ ) migrate to spawning grounds in spring or summer, swimming at depths of 50-150 m.

In contrast to albacore, bluefin tuna spawn in more enclosed areas such as the Mediterranean Sea and the northern Gulf of Mexico (Mather et al., 1995). There may be other spawning areas as well. Based on historic data, maturity ogive research and electronic tag results, the Bahamas, Caribbean Sea, and Gulf Stream margin have been hypothesized to be spawning areas for western bluefin tuna (Mather et al., 1995; Lutcavage et al., 1999; Goldstein et al., 2007; Galuardi et al., 2010). Skip spawning is also characteristic of this species with some recently matured bluefin tuna may skip spawning in some years (Rooker et al., 2007; Goldstein et al., 2007; Galuardi et al., 2010) an occurrence supported by life history modelling (Chapman et al., 2011). Finally, bluefin tuna have apparently spawned 
1 in the Black Sea (Mather et al., 1995; Zaitsev, 2003;MacKenzie and Mariani 2012) before

2 their disappearance in the late 1980s (Karakulak et al., 2004). After spawning, adult bluefin 3 generally migrate to foraging areas in the Bay of Biscay, Canary Islands areas, west of Ireland,

4 North Sea, Norwegian Sea, south of Iceland, the Gulf of Maine, Scotian Shelf, Gulf of St.

5 Lawrence, and north coast of Newfoundland (Avalon Peninsula). Some bluefin make trans-

6 Atlantic transits to distant feeding grounds and back during a single season (Galuardi et al.,

7 2010); larger individuals tend to make the longest migrations (Mather et al., 1995; MacKenzie

8 and Myers, 2007; Galuardi et al., 2010). Changes in the timing of feeding migrations of bluefin

9 tuna and albacore have been observed with spawners arriving progressively earlier in the Bay

10 of Biscay over the last decades (Dufour et al. 2010) potentially evidence of the impact of

11 climate warming on these species.

12 The vertical distribution of albacore has been observed directly by electronic tagging 13 (Domokos et al., 2007; Childers et al., 2011) and acoustic telemetry (Laurs et al., 1980; Laurs 14 and Lynn, 1991) or indirectly by the depth of longline hooks (Bard et al., 1999; Bertrand et 15 al,. 2002). The depth distribution varies between the surface and $450 \mathrm{~m}$ depending on size and 16 ambient temperature and the diurnal cycle. Juvenile albacore, during their feeding migration 17 to the NE Atlantic (Goñi et al., 2009), seem to occupy surface waters, usually staying above 18 the thermocline, while adult fish, whose swim bladder is fully developed, are more capable of exploiting deeper resources.

\subsubsection{Life history}

Environmental processes affecting growth, maturation, recruitment, and the timing of migrations are not well documented for albacore and bluefin tuna (see review in ICCAT 2010a,b). However, time series analyses showed that some large-scale climatic factors (e.g., NAO, temperature, precipitation) can explain some of the variation in long-term fluctuations in Mediterranean trap catches of bluefin adults during the 1800s-early 1900s, with time lags suggesting climatic-hydrographic effects on eggs, larvae and early juveniles (Ravier et al., 2004) even if the mechanisms remain obscure. In the case of albacore, recruitment seems also

30 affected by large-scale environmental variability, but the mechanisms are not clearly identified 31 (Arregi et al., 2006).

32 Compared to more tropical tunas such as yellowfin and skipjack tuna, albacore and bluefin 33 have longer life spans, over 15 and 20 years respectively. Natural mortality is much higher for 34 young than for adult fish. Age at first maturity is reached at $80 \mathrm{~cm}$ for albacore (5 yrs and 90 
$1 \mathrm{~cm}$ for $50 \%$ mature fish) and between 4 years $(115 \mathrm{~cm})$ and 6-8 years $(190 \mathrm{~cm}$ or less) for east 2 and west stocks respectively of Atlantic bluefin (Baglin, 1982; Medina et al., 2002;

3 Heinisch et al., 2010). High fecundity is a characteristic of all tunas and tuna-like fishes,

4 with females spawning several million eggs per year.

5 Albacore maximum length is $122 \mathrm{~cm}$, with males growing larger than females (Santiago and 6 Arrizabalaga, 2005). They show strongly seasonal growth, with higher growth rates in the 7 summer feeding season in the Bay of Biscay and surrounding waters of the NE Atlantic.

8 Growth is rapid in early life stages, and slows down with age. Adult albacore can grow to 40 $9 \mathrm{~kg}(120 \mathrm{~cm})$, while bluefin tuna can reach over $600 \mathrm{~kg}(>250 \mathrm{~cm})$. Eastern and western bluefin tuna grow at similar rates (Restrepo et al., 2010), eat similar prey (Logan et al., 2011), share feeding grounds, and are likely to have similar life history profiles (Chapman et al., 2011). Recent studies confirm that east-west differences in size and age at maturity are much less than previously assumed, with some western fish maturing at $160 \mathrm{~cm}$ or less (Knapp et al, 2009). Availability of prey and migration distance have been shown to affect bluefin life history traits such as age of maturity and spawning frequency and migration distances (Chapman et al., 2011).

\subsection{Swordfish and blue marlin}

\subsubsection{Geographic distribution}

North Atlantic swordfish are considered a subtropical species, but they are also common in temperate waters (Fromentin and Fonteneau, 2001). Mejuto and Hoey (1991) based on reviewing the literature concluded that an appropriate model for swordfish distribution in the North Atlantic would be one of seasonal expansion and contraction around the equatorial region, with the largest individuals showing the greatest range - similar to bluefin tuna. There are relatively few records of movement between the NW and the NE Atlantic (Neilson et al., 2009) compared to blue marlins and bluefin tuna. Instead, there are relatively discrete northsouth migratory pathways with individuals marked in Canadian waters typically spending winter months, presumably for spawning, in the Caribbean/Sargasso Seas (Neilson et al., 2009). Those authors also described a striking fidelity to foraging sites.

In contrast to swordfish, blue marlin are found in the Atlantic, Pacific and Indian oceans, with genetic evidence indicating that they form a single species across their range (Collette et al., 2006). Blue marlin occur in tropical to temperate waters, with the highest abundances in waters $>25^{\circ} \mathrm{C}$. This temperature association results in a broader latitudinal range for blue marlin in the 
1 western Atlantic versus the eastern Atlantic. Conventional tagging data shows that individuals

2 cross the Atlantic and the equator, with one individual even exhibiting inter-ocean

3 movement (Orbesen et al., 2008). No range changes have been found for blue marlin over the

4 past half-century (Worm and Tittensor, 2011). Interannual variability in blue marlin

5 distribution has been documented in the Pacific Ocean in response to El Nino Southern

6 Oscillation events (Su et al., 2011) but not for the Atlantic. At finer spatial scales, interannual

7 variability in recreational blue marlin catch has been associated with the presence of cyclonic

8 eddies, with catches occurring in the frontal region of the eddy (Seki et al., 2002).

\subsubsection{Spawning habitats and migrations}

Spawning areas for swordfish are geographically extensive, with the main spawning areas being south of the Sargasso Sea and east of the Antillean Arc. The spawning period is latitude dependent, and spans the whole year. Reproductive activity has been associated with surface $23-26^{\circ} \mathrm{C}$ isotherms (Tåning, 1955; Mejuto and Hoey, 1991), or possibly isotherms below the surface (Mejuto and García, 1997). It has been suggested that these oceanographic features are similar on the spawning grounds in the NW Atlantic and in the South Atlantic (Mejuto and García, 1997). Recent genetic analyses have revealed separation of populations in the NW and South Atlantic, though there might be some mixing between NW and NE Altantic populations (Alvarado Bremer et al., 2005). It has been widely hypothesized that swordfish eggs and larvae in the Northwest Atlantic may be carried from the spawning grounds via the Gulf Stream system to adjacent areas (Arata, 1954; Tibbo and Lauzier, 1969). Oceanographic features such as independent eddies from the Gulf of Mexico (Markle, 1974) and filaments and trajectories from the Gulf Stream (Govoni et al., 2000) may be responsible for altering the pathways for larval transport. Swordfish retain their larval characteristics to a length of at least 188mm (Govoni et al., 2000), and passive transport has been assumed to some extent for larvae up to $115 \mathrm{~mm}$.

For blue marlin numerous spawning locations have been documented: larvae have been collected in the waters offshore of Brazil, the Outer Bahamas, the Mona Passage off the Dominican Republic, the Gulf of Mexico, and in the Straits of Florida (Richardson et al., 2009). However, spawning habitat does appear to be restricted by temperature. Blue marlin larvae are generally only collected in areas with surface temperatures $>28^{\circ} \mathrm{C}$, with higher densities between 28 and $30^{\circ}$ (Rooker et al., 2012).

During times of the year when swordfish are actively foraging in more northerly latitudes, 
1 they show a distinct and predictable form of vertical migration. The behaviour seems to

2 follow the movement of mesopelagic organisms in the deep scattering layer (Carey, 1990). At

3 night, swordfish tend to remain in the mixed layer, where they can feed and recover from a

4 thermal or oxygen debt acquired by day.

5 The vertical movement patterns of adult blue marlin are strongly tied to oxygen and

6 temperature levels. Satellite tagging studies have shown that blue marlin are within the mixed

7 layer about $85 \%$ of the time during the night and about $60 \%$ during the day. However they

8 also make frequent short duration dives below the mixed layer; the minimum temperatures

9 experienced during these dives are generally $17-18^{\circ} \mathrm{C}$ (Goodyear et al., 2008). In the eastern

10 Atlantic, levels of dissolved oxygen are the primary factor limiting the dive depths, a factor

11 that likely increases the susceptibility of blue marlin to bycatch in surface fishing gear

12 in these regions (Prince et al., 2010).

13

14

15

16

\subsubsection{Life history}

Swordfish are among the largest of the teleosts, reaching a maximum weight in excess of 500 kg. Rouyer et al. (2010) found that catch rates of the larger, slower-growing and later- maturing species such as swordfish and blue marlin showed links with environmental conditions. These authors considered swordfish to be slow growing, but there is virtually no information on environmental influences on growth processes due to a paucity of age and other life history information.

Blue marlin exhibit substantial sexual dimorphism in size; females reach a maximum weight of $>500 \mathrm{~kg}$ and males reach $\approx 160 \mathrm{~kg}$ (Wilson et al., 1991). The maximum longevity of blue marlin is uncertain as larger fish are difficult to age (Drew et al., 2006). However, in tagging studies blue marlin have been recaptured 12 years after release (Orbesen et al., 2008). For blue marlin substantial seasonal variation occurs in the sex ratio within specific regions, probably reflecting behavioural and habitat differences. In the Pacific, spawning has been estimated to occur every 2.4 days over a 4-5 month season (Sun et al., 2009). A similar season of extended repeat spawning also occurs in the Straits of Florida (Richardson et al., 2009). The average blue marlin batch fecundity in the Pacific is estimated at 7 million eggs.

The growth of the early life stages of blue marlin is extremely rapid with egg development times of approximately one day. Large variations in larval growth have been found between regions (Sponaugle et al., 2005). These differences were unrelated to water temperature, and it was speculated that they could have been driven by differences in larval prey field between 
1 regions or maternal effects if the size-structure of the spawning fish differed between

2 regions. Larval mortality rates of blue marlin are very high and have been estimated at $30 \%$ 3 per day (Richardson et al., 2009).

$4 \quad 3.3$ Knowledge gaps

12

Little is currently known about environmental or biological factors impacting life history traits of albacore, bluefin, swordfish and blue marlin in the North Atlantic (Table 1). Dedicated data analysis and modelling studies to elucidate the roles of environmental conditions and fishing in shaping population dynamics, spatial distributions and migrations are needed for all four species. These species also have in common that their spawning grounds are only partially or unprecisely known.

\section{Diet and predators of small and medium sized pelagic fish species in the North Atlantic}

In this section, we review the available knowledge of the diet (prey) of each species, as well as their predators. We strive as much as possible to elucidate regional differences.

\subsection{Herring}

\subsubsection{Prey}

Adult herring are opportunistic and feed on a variety of zooplankton and the larval stages of fish and invertebrates depending upon the location. However, throughout their range their primary food are copepods, such as Calanus and Pseudocalanus spp., and other small crustaceans (Scott and Scott, 1988; Prokopchuk and Sentyabov, 2006).

In the Norwegian Sea, Calanus finmarchicus is the dominant zooplankton species (Wiborg, 1955), making up $80 \%$ of the annual zooplankton production and the primary adult herring prey (Gislason and Astthorsson, 2002; Dommasnes et al., 2004; Prokopchuk and Sentyabov, 2006). NSSH follow C. finmarchicus through the Norwegian Sea, resulting in a general clockwise migration pattern during the feeding period. The quantity of C. finmarchicus that contributes to the total herring diet varies from $0-99 \%$ depending on the temporal and spatial distribution of herring.

Food composition of herring in the NW Atlantic varies in a similar way to the NE Atlantic, being dominated by one or two primary species, but including other organisms of appropriate size. The main prey of herring in Gulf of St Lawrence are also Calanus copepods, followed by capelin and euphausiids (Darbyson et al., 2003). It is not uncommon to find herring eggs in 
1 the stomachs of pre-spawning herring collected on spawning grounds in coastal and 2 Southwest Nova Scotia (Gary Melvin, pers com.). The most important prey for herring 3 collected on Georges Bank were chaetognaths, euphausiids, pteropods and copepods and in the 4 Gulf of Maine it was euphausiids and copepods. In some areas herring have been found to feed 5 on 0-group fish, including capelin, Sebastes spp. and herring themselves (Holst et al., 1997). 6 Fish prey can even dominate the diet in some areas. Predation by juvenile NSSH in the Barents Sea is considered to impact year class strength of the local capelin stock, in addition to predation by 0-group cod and adult cod (Hjermann et al., 2010; Frank et al., 2011). On Georges Bank in the NW Atlantic, predation including that by herring, is believed to have contributed to the lack of a recovery of cod (Quinlan et al., 2000; Tsou and Collie, 2001; Murawski, 2010). In the North Sea where a more diverse group of prey organisms occur the principal herring prey are copepods (Calanus finmarchicus and Temora longicaudata), however, euphausids and post-larval fishes (Ammodytes spp. and clupeoids) and fish eggs (Pleuronectes platessa, and pelagic fishes) contribute also to their diet (Last, 1989; Segers et al., 2007). The summer of 2010 was anomalous with respect to weight-at-length, condition factor and fat content for a number of fish stocks on both sides of the north Atlantic (ICES, 2010b). Simultaneously, results from an international survey in the Nordic Seas in May indicated that zooplankton abundance had been declining, and in 2009-2010 it was at its lowest level since sampling started in 1997 (ICES, 2011d). Similar observations have also been reported for herring in the Gulf of Maine, Southwest Nova Scotia and the Gulf of St Lawrence where there is some evidence that the mean weight at age has been declining for several decades. Melvin and Martin (2012) found a significant relationship between mean monthly sea surface temperature, chlorophyll and herring body condition for specific months. They also noted that the decrease was not the same throughout the stock complex and varied among regions in the same stock. These observations could indicate a resource control on herring which would work via chlorophyll (plankton production), zooplankton through to fish growth on the western

28 Atlantic. These observations evoke not only questions about trophic control but also about carrying capacity of the regional seas and gulfs.

\subsubsection{Predators}

Herring are eaten by many predators at every stage from eggs to adult, and they are a key 34 link in the transfer of energy from one trophic level to another in many ecosystems of the 
1 North Atlantic. Eggs are preyed upon by numerous species of ground fish, invertebrates, and 2 pelagic species, including herring themselves. As larvae they are consumed by fish and 3 planktonic invertebrates, and filter feeding mammals. Once herring metamorphose into 4 juveniles they become important prey for a wide variety of marine and terrestrial organisms, 5 including seabirds which depend upon these small fish to feed the recently hatched chicks. As 6 they increase in size so does the size of the predators feeding on them, and even the largest 7 herring have several species that depend upon them for a major portion of their food 8 consumption. Large predators of herring include seals, toothed whales (e.g. killer whale 9 Orcinus orca), minke whale (Balaenoptera acutorostrata), fin whale (Balaenoptera 10 physalus), humpback whale (Megaptera novaeangliae) and dolphin species, tuna (see below) 11 and tuna like species, seabirds and various demersal fish species (Sigurjónsson and 12 Víkingsson, 1997; Overholtz and Link, 2007).

13 The total consumption of herring by predators is generally unknown and even when estimated 14 it is usually only available for individual predator species or groups. Nevertheless, an estimate 15 of total consumption of the Gulf of Maine-George Bank herring complex has been performed, 16 and has shown that demersal fish species were the most effective predators, followed by 17 marine mammals and large pelagic fish (Overholtz and Link, 2007). Changes in abundance of 18 both prey and predators can cause major fluctuations in the estimate of total consumption 19 (Overholtz et al., 2000).

20 In the Norwegian Sea the predation pressure on NSSH during the feeding season is considered 21 low as the whales focus more on zooplankton or capelin. Saithe (Pollachius virens) is 22 known to prey on herring during the spawning period and they are believed to follow 23 herring into the Norwegian Sea, but the extent of this is difficult to evaluate since there are 24 very few samples of saithe from this area. In other areas of the north Atlantic, where herring 25 aggregate for feeding, spawning, or overwintering, they are also followed by their predators 26 (Parrish, 1993; Pitcher et. al., 1996; Read and Brownstein, 2003). It is not uncommon to observe whales, seals, seabirds, tuna, and a multitude of groundfish species feeding on herring 28 spawning aggregations (Christensen, 1988; Purcell, 1990; Lindstrøm et al., 2000; Nøttestad, 29 2002; Overholtz et al. 2008). In some areas groundfish fisheries concentrate on herring 30 spawning grounds to take advantage of their increased density and their eggs laying on the 31 seafloor which attract demersal fish that feeds on them (Toresen, 1991; Livingston, 1993).

\subsection{Mackerel}




\subsubsection{Prey}

4 Early life stages of Atlantic mackerel are characterized by fast growth and early feeding on copepod nauplii followed by a switch to piscivorous feeding habits at about $7 \mathrm{~mm}$ (Mendiola, et al., 2007; Robert et al., 2008). Early stages of mackerel exhibit selective feeding with calanoid copepods being preferred over cyclopoid copepods (Ringuette et al., 2002; Robert et al., 2008). When the larvae are $>6 \mathrm{~mm}$ and the potential growth rates are still increasing (Bartsch, 2002), high energy rich fish larvae become a central prey item. Piscivorous and cannibalistic feeding has been noted in all studies analysing mackerel larval feeding habits (Lebour, 1920; Grave, 1981; Ware and Lambert, 1985; Hillgruber and Kloppmann, 2001; Robert et al., 2008) with the exception of Last (1980), but this might be due to misidentification (Hillgruber and Kloppmann, 2001). Cannibalism was observed to be more prevalent at higher temperatures and increased with age and size (Mendiola et al., 2007). Comprehensive lists of prey species found in mackerel larvae stomachs are provided by Hillgruber and Kloppmann (2001), Robert et al. (2008), Hillgruber et al. (1997) and in references therein.

Juvenile and adult Atlantic mackerel are opportunistic feeders that can ingest prey either by particulate or filter feeding. They feed on a wide variety of zooplankton and small fish. Feeding behaviour and diet vary seasonally, diurnally, spatially and with size. Prey preference is positively size selective. Larger fish larvae are preferred over smaller larvae (Pepin et al., 1987; Pepin et al., 1988; Langøy, et al 2006; 2012). In the laboratory, prey size preference has been shown to be independent of prey concentration (Pepin et al., 1987; 1988). In the North Sea, the main zooplankton prey are copepods (mainly C. finmarchicus), euphausiids (mainly Meganyctiphanes norvegica) and hyperiids, while primary fish prey are sandeel, herring, sprat, and Norway pout. The most intensive period for mackerel feeding is April to August. Euphausiids are the main prey in winter and up to the beginning of spawning. Through spawning, summer and autumn, copepods and fish are also important parts of the 29 diet (Mehl and Westgård, 1983; ICES, 1997).

30 Mackerel in addition to herring is one of the major consumers of zooplankton in the 31 Norwegian Sea, in particular of the dominant C. finmarchicus (Prokopchuk and Sentyabov, 32 2006; Langøy et al., 2012). Euphausiids and Themisto spp. also make up a significant bulk of 33 the total zooplankton biomass in the Norwegian Sea (Dalpadado, 2002; Melle et al., 2004) 34 and are among the preferred prey of mackerel (Langøy et al., 2012). The sea snail Limacina 
1 retroversa may also contribute significantly to the diet in coastal Atlantic and Arctic 2 water masses, even though more by weight than by numbers (Langøy et al., 2012).

3 Mackerel has also been found to feed on adult capelin in frontal regions, illustrating their 4 opportunistic and adaptive feeding behaviour (Nøttestad and Jacobsen, 2009). NWAM 5 mackerel diet is dominated by copepods, decapods and fish larvae (Grégoire and Castonguay, 1989). Mackerel and herring are potential competitors in the Norwegian Sea both being opportunistic feeders with overlapping spatial distributions (Prokopchuk and Sentyabov, 2006). However, in some years $(2004,2006$ and 2010) the degree of overlap in selection prey a n d distribution of these two species has appeared to vary (Nøttestad et al., 2010; Utne et al., 2012b; Langøy et al., 2012). This perceived change could be due to stronger competition during the feeding season forcing the herring to the cooler fringe areas with poorer feeding. Support for this hypothesis is that herring were observed to be in poorer condition in 2010 than in previous years.

14

\subsubsection{Predators}

A range of fish, mammal and bird predators have been reported to prey on mackerel (du Buit, 1996; Hunt and Furness, 1996; Overholtz et al., 2000; Olsen and Holst, 2001; Henderson and Dunne, 2002; Lewis et al., 2003; Savenkoff et al., 2005; Trenkel et al., 2005). Locally mackerel can be important for some predators, such as killer whales in the northeast Atlantic and Norwegian Sea during summer (Nøttestad et al., Submitted).

\subsection{Capelin}

\subsubsection{Prey}

Capelin is a planktivore with the main diet items being copepods, euphausiids and amphipods (see overview in Vilhjálmsson, 1994; Gjøsæter, 1998; Carscadden et al., 2001). Generally, the importance of copepods decreases with capelin size and that of euphausiids and amphipods increases. On the feeding grounds north of Iceland, euphausiids were estimated to constitute between $74-90 \%$ of the capelin diet (in weight), with corresponding estimates being somewhat lower for the Barents Sea (Vilhjálmsson, 1994). The importance of amphipods in the capelin diet is highest in the arctic waters where they are most abundant, for example in the northern Barents Sea (Gjøsæter, 1998) and the Labrador Sea (Carscadden et al., 2001). Capelin can impact euphausiid density, as shown by an inverse relationship between their respective abundance estimates (Gjøsæter et al., 2002). Hassel et al. (1991) observed that the biomass of 
1 euphausiids in the upper water column was much lower in areas where capelin was present

2 compared to where capelin was absent.

3 Competition for food with other pelagic species is probably low for Icelandic capelin as they

4 dominate the feeding grounds. In contrast, in the Barents Sea capelin may compete with polar

$5 \operatorname{cod}$ (Boreogadus saida) in the eastern and northeastern part of the Barents Sea (Ushakov and

6 Prozorkevich, 2002), and with juvenile herring in the southern parts (Huse and Toresen, 1996).

7 In the Gulf of St. Lawrence in the NW Atlantic, interspecific feeding, competion of larvae of

8 capelin, smelt (Osmerus mordax) and herring was considered minimal as they occurred in

9 distinct water masses and had mainly different sizes (Courtois and Dodson, 1986). No

10 information was found concerning competition with the adult part for the capelin stocks in the

11 NW Atlantic. However, it can be expected that the more southerly and easterly distribution of

12 the stocks since the early 1990s, and thereby a less offshore distribution, might have lead to

13 increased competition with species normally occupying the continental shelves, such as 14 herring.

15

16

17

\subsubsection{Predators}

The large capelin stocks in the North Atlantic are important prey for a number of finfish, bird (Barrett et al., 2002; Carscadden et al., 2002), and marine mammal species (Carscadden et al., 2001; Dolgov, 2002). Gjøsæter (1989) considers capelin to play a key ecological role as an intermediary between zooplankton and higher tropic levels. Both cod and Greenland halibut (Reinhardtius hippoglossoides) feed heavily on capelin. The growth rates, somatic weight, and/or liver conditions of cod have been found to be positively related to biomass of capelin in the Barents Sea (Yaragina and Marshall, 2000), around Iceland (Vilhjálmsson, 2002) and in the NW Atlantic (Sherwood et al., 2007). Considering that capelin are an important forage species for many stocks, changes in their spatial distribution are likely to have significant consequences for their predators. For example, observed changes in capelin distribution, most likely caused by environmental factors, lead to them being less accessible to Greenland halibut (Dwyer et al., 2010), cod in the NW Atlantic (Rose and O'Driscoll, 2002), and mature cod in Icelandic waters in the 2000s (Marine Research Institute, 2010). Capelin larvae are also heavily predated on. As mentionned above, predation by juvenile herring in the Barents Sea is considered to affect the year class strength of capelin (Hamre, 1994; Gjøsæter and Bogstad, 1998; Huse and Toresen, 2000); no information is available for predation on capelin larvae in Icelandic waters. The overlap between predators 
1 and juvenile capelin is usually higher than that for pre-spawning mature individuals which

2 have a more oceanic distribution (Vilhjálmsson, 1994; Gjøsæter, 1998; Carscadden et al., 3 2001).

$\frac{4}{5}$

\subsection{Blue whiting}

\subsubsection{Prey}

Blue whiting is a planktivorous species, with its dominant prey changing throughout lifetime. The diet of larval blue whiting consists predominately of Calanus spp, Pseudocalanus spp., Arcatia spp. and Oithona spp., with little or no phytoplankton or ichthyplankton (Conway, 1980). The diet of the juveniles and adults appears to be dominated by euphausiids together with Calanus spp; small fish (Norway pout, pearlsides) also appear to be a part of the diet of the largest adults (Bailey, 1982; Bergstad, 1991; Dolgov et al., 2009). The abundance of all of these prey groups in the North Atlantic has been shown to have links to the sub-polar gyre (Hátún et al., 2009a) and therefore changes in the available prey for blue whiting can be expected as a consequence of environmental change.

As one of the major (by biomass) pelagic planktivorous species in the North Atlantic, it is almost inevitable that blue whiting competes with other species for resources. A recent study in the Barents Sea showed a high degree of dietary overlap between blue whiting and capelin, but also with herring and polar cod (Dolgov et al., 2009). It has recently been conjectured that the high abundance of pelagic fish in the Nordic Seas may be too large to be supported by the system's secondary (zooplankton) production (e.g. Payne et al 2012) although quantitative analyses capable of exploring this hypothesis in detail have yet to be carried out.

\subsubsection{Predators}

Important predators of the southern component of blue whiting are hake in the Bay of Biscay (Guichet, 1995; Mahé et al., 2005) and hake, saithe, megrim, cod and whiting in the Celtic Sea (Pinnegar et al., 2003), in particularly during the summer months (Trenkel et al., 2005). Hake, saithe, and squid are potential predators in the northern regions (Bailey, 1982). Juvenile blue whiting have been identified as the main prey species of mackerel around the Iberian coast during autumn (Cabral and Murta, 2002; Olaso et al., 2005). Mackerel is hypothesised to be a major, and possibly controlling predator on juvenile blue whiting throughout its range (Payne et al., 2012). Several whale species also feed on blue whiting in the Bay of Biscay (Spitz et al., 2011), as does bluefin tuna. 


\subsection{Horse mackerel}

\subsubsection{Prey}

Horse mackerel is a planktivore, with the dominant prey being euphausiids and copepods, but also fish (Macer, 1977). Given its spatial overlap with other planktivores such as mackerel, blue whiting, and sardine, it is also likely to compete with these species for food, especially at an early age (Cabral and Murta, 2002).

In the eastern part of the North Sea (off Jutland) horse mackerel were found to forage predominantly on fish (Dahl and Kirkegaard, 1987), with 0-group whiting being the most important prey, followed by other gadoids and herring. A shift in prey preference with age has been found: smaller individuals $(<20-24 \mathrm{~cm})$ preyed mostly on crustaceans, gobies and haddock, while larger specimens shifted towards herring. For the Bay of Biscay, Letaconnoux (1951) and Olaso et al. (1999) provided a description of the horse mackerel diet. These observations indicated possible seasonal differences: during spring they preyed mainly on crustaceans, while in the autumn larger individuals $(>30 \mathrm{~cm}$ ) began to prey on fish (blue whiting, gobiids, anchovy), which represented $45 \%$ of the food volume in this size-range.

\subsubsection{Predators}

Horse mackerel is an important prey for cod, hake, megrim and whiting in the Celtic Sea, together with blue whiting (in summer) and mackerel (in winter) (Trenkel et al. 2005); it is also abundant in hake stomachs from the Bay of Biscay (Guichet, 1995; ) and those of a number of piscivores fish in the Cantabrian Sea (Preciado et al., 2008). In the Celtic Sea hake diet was found to reflect horse mackerel availability (Pinnegar et al., 2003), similarly in the Cantabrian Sea (Preciado et al., 2008). Horse mackerel are also consumed by bleufin tuna (see below).

\section{Diet and predators of large pelagic fish species in the North Atlantic}

\subsection{Albacore}

\subsubsection{Prey}

Albacore is considered an opportunistic predator. In the Northeast Atlantic it has been reported to feed on fish, crustaceans and cephalopods with the most frequent and widespread prey being the euphausiid crustacean Meganyctiphanes norvegica (Aloncle and Delaporte, 1974; Ortiz 
1 de Zarate et al., 1987; Pusineri et al., 2005; Goñi et al. 2011). The most western investigations

2 (up to $30^{\circ} \mathrm{W}$ ) were performed by Aloncle and Delaporte (1974) who found albacore fed mainly 3 on amphipods (Themisto gaudichaudii), krill (Meganyciphanes norvegica) and the pelagic

4 fish Cubiceps gracilis around the Azores islands. In the Bay of Biscay and surrounding 5 areas, in addition to krill the sternoptychid fish Maurolicus muellerii as well as paralepidid fish 6 represented an important part of albacore diet (Aloncle and Delaporte, 1974; Pusineri et al., 7 2005). However, as these species have become scarce in more recent years (Goñi et al., 2011), 8 age-0 blue whiting has become a key prey, particularly along the shelf-break of the Bay of 9 Biscay. Atlantic saury (Scomberesox saurus) have also been reported as an important prey for 10 albacore in this zone in all studies to date. However, Atlantic saury is scarcer in the 11 inner Bay of Biscay where sea surface temperature is higher (Aloncle and Delaporte, 12 1974). Anchovy is an important prey for albacore within the Bay of Biscay, mainly in the 13 southern part (Ortiz de Zarate, 1987; Goñi et al., 2011), but is absent from the diet outside the 14 bay. Average daily consumption of anchovy by albacore is around 10 individuals per day although after the recovery of the anchovy stock in 2010 as many as

16103 individuals have been found in an individual stomach (N Goñi, pers. 17 comm.).

18 The main spatial pattern in albacore diet is the difference between shelf-break areas and 19 more oceanic areas with higher proportions of fish at the shelf break and more small 20 crustaceans in oceanic waters (Goñi et al., 2011). In terms of feeding strategy, at the shelf21 break albacore feed in the epipelagic layer during both daytime and night. In oceanic zones 22 they feed in the epipelagic layer by night and dive into mesopelagic and/or bathypelagic 23 layers to feed during the day (N Goñi pers comm.). These observations, together with the 24 seasonal distribution of the fishing activity by surface gears (Sagarminaga and Arrizabalaga, 25 2010), suggest that the shelf-break areas are the main feeding areas for albacore in the NE 26 Atlantic, whereas more oceanic areas would correspond to the last stages of the migration.

27 Current albacore diet studies concern mainly juveniles, which compose the majority of 28 albacore catches by surface fleets in the NE Atlantic. Their feeding ecology in the NW 29 Atlantic has not been studied to date.

\subsubsection{Predators}

Albacore is a top predator which probably has predators for juvenile stages.

\subsection{Bluefin tuna}


4

\subsubsection{Prey}

Bluefin tuna in the north Atlantic consume a variety of fish species, as well as crustaceans and squid. Common fish prey species include herring, mackerel, anchovy, sardine, sprat, silver hake, squid, and demersal fish and invertebrate species, particularly in shallow continental regions (Chase, 2002; Rooker et al., 2007; Logan et al., 2011). Bluefin tuna in the North Sea and the Norwegian Sea consume herring, mackerel, sprat, garfish and gadoids (Tiews, 1978; Mather et al., 1995). Adult bluefin tuna in the Gulf of Maine primarily eat herring, sandlance and mackerel (adults) (Crane, 1936; Chase, 2002; Estrada et al., 2005; Golet et al., 2007), while over a broad shelf area juvenile bluefin target sand lance (Chase, 2002; Golet et al., 2007; Logan et al., 2011). In the western Atlantic, stomach content analysis of long line caught bluefin and diving records from electronic tags show that in oceanic regions bluefin dive deeply and heavily target squids, with myctophids and other species identified to a lesser extent (Wilson et al, 1965; Logan et al., 2011). Stomach content studies of bluefin tuna captured south of Iceland in the late 1990s-early 2000s showed that diets in these waters were composed of an unidentified mixture of fish, crustacean and squid species (Olafsdottir and Ingimundardottir, 2000), although in 2011 they appeared to be targeting mackerel aggregations. The amount of prey consumed, and thus the predation impact that bluefin tuna formerly had in the North Sea has been estimated to be between 150-200,000 t of prey. Most (probably 75\%) of this prey was herring (Tiews, 1978). This level of consumption occurred over a relatively short season because bluefin tuna were present in the North Sea for only 2-3 months per year (Tiews, 1978). The level of herring consumption by bluefin tuna in the 1950s was recently compared to consumption by all other predators (MacKenzie and Myers, 2007). The long-term mean consumption of herring by other predators was ca. 600,000 $\mathrm{t}$ during the mid-1960s-early 2000s (ICES, 2005). The bluefin consumption of herring could have been as high as $30 \%$ of that consumed by other predators, although in a much shorter period. This comparison suggests that predation by bluefin tuna on North Sea herring may have been quite substantial, and that bluefin tuna may therefore have been an important regulator of food web structure. The consumption of prey in the North Sea allowed bluefin tuna to increase their weights and condition factors before starting the return migration to southern waters in autumn (Tiews, 1978). Similar comparisons of predation impacts and condition have been conducted in the Gulf of Maine (Golet et al, 2007) and reveal relationships with prey availability, size, and energy status. In particular, significant associations between Atlantic bluefin tuna and 
1 Atlantic herring schools were identified (Golet et al., 2011), although long-term shifts in

2 Atlantic herring distributions did not follow the same trend as for Atlantic bluefin tuna.

3 The published dietary studies are mainly based on adult bluefins. Juvenile (ages 1-4) prey also

4 on fish but also other lower trophic levels as revealed by both stomach content and isotopic

5 analyses (Sara and Sara, 2007, Logan et al., 2011). Juvenile bluefin in the Bay of Biscay

6 preyed primarily on 0-group anchovy, blue whiting, horse mackerel with myctophids, krill,

7 swimming crabs and squid being consumed seasonally. Sandlance were the dominant prey

8 species of juveniles in the Mid Atlantic Bight (Eggleston and Bochenek, 1990; Logan et al.,

9 2011). This pattern is evident both in periods when sand lance was abundant and relatively rare.

10 Other species of prey such as Atlantic mackerel, herring, butterfish and longfin squid were

11 consumed in lesser amounts. In contrast, in the Bay of Biscay, consumption of anchovy seems

12 to co-vary with local abundance, as consumption declined when the biomass of anchovy

13 declined, and the consumption of some alternative prey species (e.g., krill) increased.

14 Comparison of the estimated trophic levels of prey consumed based on prey remains in

15 stomachs and isotopic measurements of bluefin tuna liver and muscle showed that trophic

16 levels were lower based on isotopic evidence.

17 Significant reduction in the condition of adult bluefin tuna in the Gulf of Maine has been 18 linked to changes in the condition and availability of larger herring (Golet et al., 2007), 19 possibly due to regional depletion, and bottom-up changes in trophic structure linked to 20 oceanographic conditions (Golet et al., unpublished results). Prey switching is the norm for 21 adult bluefin schools in the Gulf of Maine, where schools travel up to $75 \mathrm{~km} \mathrm{~d}^{-1}$ and may 22 switch feeding from sandlance to herring or other small pelagic species (Lutcavage et al., 23 2000; Gutenkunst et al., 2007).

\subsubsection{Predators}

Bluefin tuna is a top predator but which has predators for juvenile stages.

\subsection{Swordfish}

\subsubsection{Prey}

Swordfish as with tunas maintain their eyes and the central nervous system above ambient 37 temperature, as a result having a vision system with high temporal resolution which is an 38 advantage for hunting species (Fritches et al, 2005). The dominant prey swordfish consume are 39 fish and cephalopods with crustaceans being a secondary prey type (Chancollon et al., 
1 2006). Lanternfish, including Notoscopelus kroeyeri and Symbolophorus veranyi, are abundant,

2 but paralepidids, Atlantic pomfret (Brama brama), and squid (Todarodes sagittatus,

3 Ommastrephes bartramii, and Gonatus steenstrupi) dominate the diet by mass. Swordfish

4 also appear to show feeding plasticity both among different areas and among animals in the

5 same area. In the NW Atlantic, swordfish prey include several families of mesopelagic fish

6 (Paralepididae, Myctophidae) and squid (Illex illecebrosus) (Stillwell and Kohler, 1985).

7

8

9

\subsubsection{Predators}

Larval swordfish are eaten by surface dwelling fishes, including larger swordfish (Scott and Scott, 1988). Yabe et al. (1959) described predation of young swordfish by blue sharks (Prionace glauca). As adults, swordfish have few natural enemies, but shortfin mako (Isurus oxyrinchus) sharks are frequently associated with attacks on hooked or harpooned swordfish (Scott and Scott, 1988).

\subsection{Blue marlin}

\subsubsection{Prey}

Blue marlin are opportunistic feeders with substantial regional variation in their diets. For example the dominant prey items in blue marlin stomach contents were pomfret (Brama brama) and a squid (Ornithoteuthis antillarum) off Brazil (Junior et al., 2004), whereas skipjack (Katsuwonus pelamis) dominated in the western Pacific (Shimose et al., 2006), and frigate mackerel (Auxis thazard) in the Caribbean (Erdman, 2011). Analyses of food web structure consistently indicate that blue marlin is one of the top predators in pelagic ecosystems (Dambacher et al., 2010).

In contrast to the adults, larval blue marlin are highly selective feeders. In the Straits of Florida, about $90 \%$ of stomach contents of small $(<5 \mathrm{~mm})$ larval blue marlin were either a specific genus of copepod (Farranula) or a cladoceran (Evadne). The onset of piscivory occurred at $5 \mathrm{~mm}$ with exclusive piscivory occurring at $12 \mathrm{~mm}$. Remarkably, despite the low productivity in the Straits of Florida relative to more temperate areas, blue marlin larvae had a high feeding incidence of $98 \%$ (Llopiz and Cowen, 2008).

\subsubsection{Predators}

Blue marlin is a top predator which probably has predators for juvenile stages. 


\section{Discussion}

Having reviewed the literature we can now come back to the questions formulated in the Introduction: What are the commonalities and differences in distribution and life history of pelagics species across the North Atlantic? What are the commonalities and differences in their trophic roles? What models exist for evaluating environmental and fishieries impacts on the structure and functioning of North Atlantic ecosystems?

\subsection{Commonalities and differences in distribution and life history of pelagic species across the North Atlantic}

A striking difference in the ecology of small pelagics between the NE and NW Atlantic is the extent of horizontal migrations. In the NE Atlantic these stocks perform extensive migrations and capitalize on large feeding grounds in the Nordic Seas and adjacent areas (Vilhjálmsson, 1994; Dragesund et al., 1997; Jakobsson and Østvedt, 1999; Nøttestad et al., 1999; Holst et al., 2002; Utne et al., 2012b). Comparable excursions into the adjacent Labrador Sea, for example, are not commonly seen on the western side of the Atlantic. There are clear differences in the temperature regime, which likely affects the profitability of foraging in the ocean basins. The Labrador Sea is downstream of the cold East Greenland current, whereas the Norwegian Sea on the other hand is downstream of the North Atlantic Current, which provides a great heat contribution to this area (Blindheim, 2004), making it a highly profitable feeding area for pelagic fish (Skjoldal, 2004). In particular the frontal areas in the western parts of the Norwegian Sea are used extensively as a feeding area during the summer (Dragesund et al., 1997; Vilhjalmsson, 1997; Jakobsson and Østvedt, 1999; Holst et al., 2002; Utne et al., 2012b). A recent review of ecosystem productivity found no apparent differences in aggregate productivity per area between ecosystems on the eastern and western Atlantic (Lucey et al., 2012). But a key difference between the east and west is that the areas of suitable habitat for pelagic fish are much more extensive in the NE Atlantic ecosystems compared to the ecosystems on the NW side and therefore support larger fisheries and fish stocks (Figure 1).

Our literature review of biological and ecological processes showed that the environment in a wider sense is a driving factor for all five small and medium size pelagic species (Table 1). In general, there are few documented differences between stocks of the same species on either side of the North Atlantic. Further, temperature impacts are a recurrent theme for all species. Environmental impacts determining larval survival and producing occasionally extremely large year classes have been observed for herring, capelin, blue whiting and horse mackerel, but not 
1 for mackerel to the same degree. However, there are differences in the knowledge level

2 between species, which makes it difficult to draw a conclusion on this question. Furthermore,

3 the degree to which recruitment variability is captured in the assessment data depends on the

4 metholology applied and the quality of the input data. For mackerel there are some challenges

5 with the available data that impact the quality of the assessment (Simmonds et al., 2010) and

6 likely underestimates recruitment variation. Furthermore fishery-independent observations of

7 mackerel stock size are only made every third year, which limits inferences about interannual

8 variation in recruitment.

9 The four large pelagic species considered differ in their habitat requirements and tolerance as

10 well as the extent of long distance migrations. Temperature and dissolved oxygen

11 concentration control spatial distribution and accessibility to feeding grounds and are important

12 factors for albacore spatial distribution (Table 1). Bluefin tuna spatial movements and 13 distribution are environmentally, but also behaviourally, driven, with effects of population 14 density possibly being important as well. Oceanographic conditions and in particular temperature plays a role for spawning habitat of blue marlin and the general horizontal and vertical distribution. For swordfish it is the Gulf Stream that influences larval dispersal and spatial distribution.

\subsection{Communalities and differences in the trophic roles of pelagic species across the North Altantic}

21 Based on the literature review, the trophic roles and controls of the studied pelagic species were determined (Table 1). In the trophic role classification, top-down effects of a species correspond to documented situations where abundance time-trends lead to detectable trends in the opposite directions in their preys, while for a bottom-up effect of a species similar time-trends in their predators have been found. If a pelagic species exerted both a top- down effect on its preys and a bottom-up effect on its predators this suggests an overall middle-out

27 food web control. Next, for all pelagic species we summarised the published evidence for their 28 population abundance to be controlled by prey availability, called resource controlled, or 29 predation pressure, called predator controlled.

30 Due to its high abundance, broad distribution and position in the food web, herring is a key 31 species in food webs throughout the North Atlantic. Herring are opportunistic zooplankton 32 feeders focusing on the different dominant zooplankton species present. They also feed on ichthyoplankton and are cannibals (Holst, 1992). Mackerel larvae and juveniles are size- and 
1 species-selective feeders while adult mackerel are more opportunistic. Apart from disparate 2 studies, the trophic role of blue whiting is poorly defined. However, mackerel, herring and 3 blue whiting might be strong competitors in certain areas, such as the Norwegian Sea 4 (Prokopchuk and Sentyabov, 2006; Langoy et al., 2012) where predation by these stocks 5 appears to be responsible for the observed strong zooplankton reduction (Huse et al., 2012). In this area there are indications that herring has been resource controlled in recent years via impacts on length growth (Huse et al., 2012). In certain ecosystems and seasons, herring therefore exert a top-down effect on their prey, but in others they can exert a bottom-up effect on their predators (see tunas below). Mackerel could also exert a bottom-up effect on some of their predators (Nøttestad et al., Submitted). For blue whiting, extensive studies and stomach sampling programmes to examine both the predators and prey of this species would greatly improve our understanding of its dynamics, and its links to the environment and rest of the ecosystem. The currently available evidence points at a possible predation (on juveniles by mackerel, Payne et al., 2012) and competition control of the blue whiting population dynamics (e.g., by capelin, herring and polar cod, Dolgov et al., 2009). Capelin play an important role in local food webs, and both top-down and bottom-up effects have been observed (Skjoldal et al., 1992; Gjøsæter, 1998). They suffer predator control primarily via predation on their larvae. Finally, little is known about the food web role of horse mackerel in spite of it being a locally important prey.

All investigated large pelagic species are more or less opportunistic feeders but due to their different spatial and vertical distributions their diet overlap is small. For example, while albacore is a nocturnal epipelagic feeder, swordfish feed during day and night in mesopelagic layers and hence the two species have different prey species and a very low trophic niche overlap (Pusineri et., 2008). It is currently unknown to what extent albacore might exert local top-down pressure. Given the observed flexibility in observed diet it seems unlikely that albacore are resource controlled. The extensive migrations of bluefin tuna for foraging imply that the predation impact by bluefin tuna on their prey populations is dispersed and seasonal; its magnitudes are not yet well documented but are probably modest to substantial. In contrast, there is evidence for local resource control of bluefin body condition. The diet of swordfish does not include any of the abundant small pelagic species considered here. There is no evidence for any type of food web effect by swordfish. Similarly for blue marlin, for which there is no published evidence for any type of food web effect in the North Atlantic. 
1 Hunsicker et al. (2012) identified the potential for top-down control of sharks and billfishes

on skipjack (Katsuwonus pelanis) and yellowfin tunas (Thunnus albacares).

\subsection{Integrating pelagic species and environmental effects into models}

A variety of approaches have been developed to model the impacts of fishing and environmental factors on the population dynamics and spatial distributions of abundant small and widely-distributed large pelagic fish species in the North Atlantic basins including capelin (Tjelmeland and Bogstad, 1998; Huse et al., 2004; Magnusson et al., 2005; Huse and Ellingsen, 2008), herring, mackerel and blue whiting (Utne and Huse, 2012). Below we will discuss some of these modelling approaches with particular relevance for the EURO-BASIN project in more detail.

A number of these models are considering food web relations explicitly. Recently different IBM models for fish and zooplankton were combined with the Norwegian Sea ecosystem model (NORWECOM) for lower trophic levels and nutrient cycling into the NORWECOM.E2E end to end model of the Norwegian Sea ecosystem (Hjøllo et al., 2012; Utne et al., 2012a). Within EURO-BASIN the NORWECOM.E2E will be further developed and expanded geographically to provide an integrated framework for modelling the spatial dynamics of some key stocks including NSSH, blue whiting and mackerel. These further model developments will take into account adaptive foraging behaviour of predators to spatial variations in prey abundance, resulting species interactions and have a closed lifecycle (Huse and Ellingsen, 2008).

The Spatial Ecosystem and Population Dynamics Model (SEAPODYM) which has been parameterised for albacore in the South Pacific (Lehodey et al., 2008; Senina et al., 2008) will be applied to the North Atlantic population. There is little evidence to suggest that the main biological characteristics of albacore (physiology and environmental preferences, lifespan, growth, spawning and feeding behaviour) vary significantly among oceans, and the South Pacific and the North Atlantic albacore stocks are very similar in terms of biological productivity when considering the levels of catch and catch rates. Therefore a first simulation will use the existing parameterisation achieved in the Pacific to test the robustness of the model. Then an optimisation experiment will be conducted with fishing data from north Atlantic fisheries (catch and size frequencies). The model will be validated by evaluating its skill in predicting spatio-temporal changes in the various albacore fisheries over the last fifty years. Further, since the feeding habitat is defined based on accessibility to diverse prey 
1 functional groups (Lehodey et al., 2010a), the model predicts also the diet by age and its 2 spatio-temporal variability. These predictions will be compared to the information collected at 3 sea (e.g., Lezama-Ochoa et al., 2010). Finally, climate change impacts on albacore population 4 will be explored using environmental forcing produced by IPCC climate models (Lehodey et 5 al., 2010b).

6 The foraging and spawning migrations of albacore and bluefin tuna have several implications 7 for the fisheries management of both stocks. First, many of the migrations involve 8 movements across stock management boundaries, and rates of migration across the stock 9 boundary can be high. For example, as many as $60 \%$ of sampled juvenile bluefin tuna in west Atlantic foraging areas were diagnosed as having been born in the Mediterranean Sea (Rooker et al., 2008). These movements and contributions to neighbouring stock dynamics and fisheries need to be incorporated into stock assessment models and fisheries management policies. Secondly, the possibility that some bluefin tuna do not spawn in some years implies that reproductive potential might vary among years, even if the spawner biomass or its age/size composition does not. IBM approaches should help to identify the link between spawning potential and environmental conditions and provide a way to introduce additional uncertainty to stock-recruitment relationships and models of stock dynamics. New modelling for the migratory behaviour of bluefin tuna will be developed to simulate migrations of adult tuna between spawning and feeding areas. A detailed description of the size-specific food and temperature requirements of individual tunas and the coupling with available physical and mid trophic layer models will allow disentangling proximate and ultimate causes of bluefin tuna migrations in the North Atlantic. Predation impacts of bluefin tuna in the simulated habitats will be predicted using a size-structured mass-balanced model (Andersen and Pedersen, 2010) to assess potential top-down effects on the local fish community.

For blue whiting a spatially-explicit closed life-history model driven by physical and biological output from coupled physical/biological ecosystem models will be developed. The population model will be based on the discrete-time length-structured approach by Andrews et al. (2006) in which increase in body size occurs through progression along a set of lengthclasses obtained from a linear transformation of von Bertalanffy growth. In space, the population will be distributed over a discrete matrix of cells. The spatial transport of pelagic eggs and larvae using a method developed for zooplankton in which transport occurs at discrete transport events (Speirs et al. 2005; 2006). At a transport event the time-dependent proportion of the population moving between cells is derived in advance from Lagrangian 
1 tracking from flow fields output from the physical models developed in Euro-Basin. Adult

2 movement will be based on a combination of diffusive movement and seasonal active

3 movements to the known spawning areas along the continental shelf edge. The computational

4 efficiency of the SU discrete-time-discrete-space approach permits the practical exploration of

5 variety of different movement rules (Andrews et al., 2006).

6

7

8

\section{Conclusions}

This review showed that there are generally few differences in distribution patterns and life history parameters between stocks of the same species of small pelagics on either side of the North Atlantic, though migration distances and the overal spatial extents are much larger on the eastern side. In contrast there are bigger differences among species. For example, two small pelagic species might use broadly the same area for spawning, though at different times of the year, as is the case for mackerel and blue whiting in the NE Atlantic. Not all reviewed species have been studied with the same intensity so that there are a number of knowledge gaps, in particular with respect to structuring and critical environmental conditions for certain small pelagics and most of the large pelagic species. A striking difference between the small and large pelagic species reviewed here is that the former can be strong food competitors at times and excert both top-down and bottom-up control, while the later seem to occupy more separate trophic niches and if they are controlling food webs, this control is limited in space and time. Finally, the review demonstrated that the information required to apply the new more holistic spatially explicit modelling approaches outlined above is sufficient except for the identified knowledge gaps, which are currently being addressed in the Euro-Basin project.

\section{Acknowledgements}

This review received funding from the European Union Seventh Framework Programme project EURO-BASIN (ENV.2010.2.2.1-1) under grant agreement $\mathrm{n}^{\circ}$ 264933. MRP acknowledges funding from the NACLIM project (grant agreement $\mathrm{n}^{\circ} 308299$ ).

\section{References}

Abaunza, P., Gordo, L., Karlou-Riga, C., Murta, A., Eltink, A.T.G.W., García Santamaría, M.T., Zimmermann, C., Hammer, C., Lucio, P., Iversen, S.A., Molloy, J., Gallo, E., 2003. Growth and reproduction of horse mackerel, Trachurus trachurus (carangidae). Reviews in Fish Biology and Fisheries 13, 27-61. 
Abaunza, P., Gordo, L.S., García Santamaría, M.T., Iversen, S.A., Murta, A.G., 2008. Life history parameters as basis for the initial recognition of stock management units in horse mackerel (Trachurus trachurus). Fisheries Research 89, 167-180.

Agnalt, A.L., 1989. Long-term changes in growth and age at maturity of mackerel, Scomber scombrus L., from the North Sea. Journal of Fish Biology 35, 305-311.

Albaina, A., Iriondo, M., Fernandez, I.V., Laconcha, U., Zarraonaindia, I., Arrizabalaga, H., Goñi, N., Lutcavage, M., Grant, W., Estonba A., 2013. Single nucleotide polymorphism discovery in albacore and Atlantic bluefin tuna provides insights into world-wide population structure. Animal Genetics, DOI: 10.1111/age.12051.

Alemany, F., Quintanilla, L., Velez-Belchi, P., Garcia, A., Cortes, D., Rodriguez, J.M., de Puelles, M.L.F., Gonzalez-Pola, C., Lopez-Jurado, J.L., 2010. Characterization of the spawning habitat of Atlantic bluefin tuna and related species in the Balearic Sea (western Mediterranean). Progress in Oceanography 86 SI, 21-38.

Aloncle, H., Delaporte, F., 1974. Données nouvelles sur le germon Atlantique Thunnus alalunga Bonnaterre 1788 dans le Nord-Est Atlantique. 1ère Partie - Rythmes alimentaires et circadiens. Revue des Travaux de l'Institut des Pêches Maritimes 37, 475-572.

Alheit, J., Hagen, E., 1997. Long-term climate forcing of European herring and sardine populations. Fisheries Oceanography. 6, 130-139.

Alvarado Bremer, J.R., Mejuto, J., Gómez-Márquez, J., Boán, F., Carpintero, P., Rodriguez, J.M., Viñas, J., Greig, T.W., Ely, B., 2005. Hierarchical analyses of genetic variation of samples from breeding and feeding grounds confirm the genetic partitioning of northwest Atlantic and South Atlantic populations of swordfish (Xiphias gladias L.). Journal of Experimental Marine Biology and Ecology 327, 167-182.

Andersen, K.H., Pedersen, M., 2010. Damped trophic cascades driven by fishing in model marine ecosystems. Proceedings of the Royal Society B 277, 795-802.

Andrews, J.M., Gurney, W.S.C., Heath, M.R., Gallego, A., O’Brien, C.M., Darby, C., Tyldesley, G., 2006. Modelling the spatial demography of Atlantic cod (Gadus morhua) on the European continental shelf. Canadian Journal of Fisheries and Aquatic Sciences 63, 1027-1048.

Anon., 1896. Twenty-Eighth Annual Report. Department of Marine and Fisheries. Dawson Press. Ottawa. Canada.

Anthony, V.C., Fogarty, M.J., 1985. Environmental effects on recruitment, growth, and vulnerability of Atlantic herring (Clupea harengus harengus) in the Gulf of Maine region. Canadian Journal of Fisheries and Aquatic Sciences 42, 158-173.

Arata, G.F., 1954. A contribution to the life history of the swordfish, Xiphias gladius Linnaeus, from the south Atlantic coast of the United States and the Gulf of Mexico. Bull. Mar. Sci. Gulf Caribb. 4:183-243.

Arbault, S., Lacroix-Boutin, N., 1969. Epoques et aires de ponte des poissons téléosteens du golfe de Gascogne en 1965-1966 (œufs et larves). Rev. Trav. Inst. Pêches Marit. 33, 181202.

Arregui, I., Arrizabalaga, H., Kirby, D. S., Martín-González, J. M., 2006. Stock-environmentrecruitment models for North Atlantic albacore (Thunnus alalunga). Fisheries Oceanography $15,402-412$.

Arnold, G.P., 1981. Movements of fish in relation to currents, in: Aidley, D.J. (ed.), Animal Migration. Cambridge University Press, Cambridge, p. 264.

Arrizabalaga, H. 2003. Estructura poblacional del atún blanco (Thunnus alalunga Bonn. 1788): una aproximación multidisciplinar. PhD Thesis presented at Universidad de Vigo (Spain), $161 \mathrm{p}$. 
Arrizabalaga, H., Costas, E., Juste, J., González-Garcés, A., Nieto, B., López-Rodas, V., 2004. Population structure of albacore Thunnus alalunga inferred from blood groups and tagrecapture analyses. Marine Ecology Progress Series, 282, 245-252.

Astthorsson, Ó., Gislason, A., 1998. Environmental condition, zooplankton and capelin in the waters north of Iceland. ICES Journal of Marine Science 55, 808-810.

Astthorsson O.S., Valdimarsson H., Gudmundsdottir A., Oskarsson G.J., 2012, Climate-related variations in the occurrence and distribution of mackerel (Scomber scombrus) in Icelandic waters. ICES Journal of Marine Science 69, 1289-1297.

Bailey, R., 1982. The population biology of blue whiting in the North Atlantic. Advances in Marine Biology 19, 257-355.

Bailey, M.C., Heath, M.R., 2001. Spatial variability in the growth rate of blue whiting (Micromesistius poutassou) larvae at the shelf edge west of the UK. Fisheries Research 50, 73-87.

Baglin, R. E. 1982. Reproductive biology of western Atlantic bluefin tuna. Fisheries Bulletin. 80, 121-134.

Bard, F.X., Santiago, J. 1999. Review of albacore (T. alalunga) historical surface fisheries data (1920-1975) for possible relationships with North Atlantic Oscillation. Col.Vol.Sci.Pap. ICCAT, 49 (4), 311-323.

Bard, F.X., Yen, S., Stein., A.1999. Habitat of deep swimming tuna (Thunnus obesus, T. albacares, T. alalunga) in the central South Pacific. Collect. Vol. Sci. Pap, ICCAT, 49, 309317.

Barrett, R.T., Asker-Nilsen, T., Gabrielsen, G.W., and Chapdelaine, G., 2002. Food consumption by seabirds in Norwegian waters. ICES Journal of Marine Science 59, 43-57.

Bartsch, J., 2002. Modelling the temperature mediation of growth in larval fish. Fisheries Oceanography 11, 310-314.

Bartsch, J., 2005. The influence of spatio-temporal egg production variability on the modelled survival of the early life history stages of mackerel (Scomber scombrus) in the eastern North Atlantic. ICES Journal of Marine Science 62, 1049-1060.

Bartsch, J., Coombs, S.H. 2004. An individual-based model of the early life history of mackerel (Scomber scombrus) in the eastern North Atlantic, simulating transport, growth and mortality. Fisheries Oceanography 13: 365-379.

Bartsch, J., Reid, D., Coombs, S.H., 2004. Simulation of mackerel (Scomber scombrus) recruitment with an individual-based model and comparison with field data. Fisheries Oceanography 13, 380-391.

Bartsch, J., Coombs, S., 1997. A numerical model of the dispersion of blue whiting larvae, Micromesistius poutassou (Risso), in the eastern North Atlantic. Fisheries Oceanography 6, 141-154.

Belikov, S.V., Jakupsstovu, S.H., Shamrai, E.A., Thomsen, B., 1998. Migration of mackerel during summer in the Norwegian Sea. ICES-CM-1998/AA:8.

Bergstad, O.A., 1991. Distribution and trophic ecology of some gadoid fish of the Norwegian Deep: 1 Accounts of individual species. Sarsia 75, 269-313.

Bertrand, A., Bard F.-X., Josse, E. 2002. Tuna food habits related to the micronekton distribution in French Polynesia. Marine Biology, 140, 1023-1037.

Bigelow, H.B., Schroeder, W.C., 1953. Fishes of the Gulf of Maine. Fish Bull Fish Wildl Serv. $74,1-577$.

Blaxter, J.H.S., Hunter, J.R., 1982. The biology of the clupeoids fishes. In: Blaxter, J.H.S., Russell, F.S., Yonge, M. (eds.) Advances in Marine Biology vol. 20. Academic Press, London, pp 1-223. 
Blindheim, J., 2004. Oceanograpy and Climate, in: Skjoldal, H.R. (Ed.), The Norwegian Sea Ecosystem, pp. 65-96.

Blindheim, J., Borovkov, V., Hansen, B., Malmberg, S. Aa., Turrell, W. R., Østerhus, S., 2000. Upper layer cooling and freshening in the Norwegian Sea in relation to atmosphere forcing. Deep-Sea Research 47, 655-680.

Block, B.A., Dewar, H., Blackwell, S.B., Williams, T.D., Prince, E.D., Farwell, C.J., Boustany, A., Teo, S.L.H., Seitz, A., Walli, A., Fudge, D., 2001. Migratory movements, depth preferences, and thermal biology of Atlantic bluefin tuna. Science 293, 1310-1314.

Block, B.A., Teo, S.L.H., Walli, A., Boustany, A., Stokesbury, M.J.W., Farwell, C.J., Weng, K.C., Dewar, H., Williams, T.D., 2005. Electronic tagging and population structure of Atlantic bluefin tuna. Nature 434, 1121-1127.

Bogstad, B., Haug, T., Mehl, S., 2000. Who eats whom in the Barents Sea? NAMMCO Sci. Pub. 2, 98-119.

Borja, A., Uriarte, A., Egana, J., 2002. Environmental factors and recruitment of mackerel, Scomber scombrus L. 1758, along the north-east Atlantic coasts of Europe. Fisheries Oceanography 11, 116-127.

Brophy, D., King, P.A., 2007. Larval otolith growth histories show evidence of stock structure in Northeast Atlantic blue whiting (Micromesistius poutassou). ICES Journal of Marine Science 64, 1136.

Brophy, D., Danilowicz, B.S., King, P.A., 2006. Spawning season fidelity in sympatric populations of Atlantic herring (Clupea harengus). Canadian Journal of Fisheries and Aquatic Sciences 63, 607-616.

Brunel, T., Dickey-Collas, M., 2010. Effects of temperature and population density on von Bertalanffy growth parameters in Atlantic herring: a macro-ecological analysis. Marine Ecology Progress Series, 405, 15-28.

Cabral, H.N., Murta, G., 2002. The diet of blue whiting, hake, horse mackerel and mackerel off Portugal. Journal of Applied Ichthyology 18, 14-23.

Carey, F.G., 1990. Further acoustic telemetry observations of swordfish. In: Stroud R. H., editor. Planning the Future of Billfishes-Research and Management in the 90s and Beyond. 2. Contributed Papers. Proceedings of the Second International Billfish Symposium, Kailua-Kona, HI, 1-5 August 1988. Savannah, GA: National Coalition for Marine Conservation, Inc. p. 103-122. Marine Recreational Fisheries, 13. 321 pp.

Carscadden, J.E., Frank, K.T., 2002. Temporal variability in the condition factors of Newfoundland capelin (Mallotus villosus) during the past two decades. ICES Journal of Marine Science 59, 950-958.

Carscadden, J.E., Frank, K.T., Leggett, W.C., 2001. Ecosystem changes and the effects on capelin (Mallotus villosus), a major forage species. Canadian Journal of Fisheries and Aquatic Sciences 58, 73-85.

Carscadden, J.E., Frank, K.T., Leggett, W.C., 2000. Evaluation of an environment-recruitment model for capelin (Mallotus villosus). ICES Journal of Marine Science 57, 412-418.

Carscadden, J.E., Frank, K.T., Miller, D.S., 1989. Capelin (Mallotus villotus) spwaning on the

42 southeast shoal - influence of physical factors past and present. Canadian Journal of Fisheries and Aquatic Sciences 46, 1743-1754.

Carscadden, J.E., Montevecchi, W.A., Davoren, G.K., Nakashima, B.S., 2002. Trophic relationships among capelin (Mallotus villosus) and seabirds in a changing ecosystem. ICES Journal of Marine Science 59, 1027-1033.

Carscadden, J.E., Vilhjálmsson, H., 2002. Capelin - what are they good for? ICES Journal of Marine Science 59, 863-869. 
Castonguay, M., Gilbert, D., 1995. Effects of tidal streams on migrating Atlantic mackerel, Scomber scombrus L. ICES Journal of Marine Science 52, 941-954.

Castonguay, M., Rose, G.A., Leggett, W.C., 1992. Onshore movements of Atlantic mackerel (Scomber scombrus) in the northern Gulf of St. Lawrence: Associations with wind-forced advections of warmed surface waters. Canadian Journal of Fisheries and Aquatic Sciences $11,2232-2241$.

Castonguay, M., Plourde, S., Robert, D., Runge, J.A., Fortier, L., 2008. Copepod production drives recruitment in a marine fish. Canadian Journal of Fisheries and Aquatic Sciences 65, $1528-1531$.

Chadwick, M., Allard, J., Dale, J., Nielsen, G., 1993. Stock composition in the 4Vn winter herring fishery. DFO Atlantic Fisheries Research Document, 93/38. 30p

Chancollon, O., Pusineri, C., Ridoux, V., 2006. Food and feeding ecology of Northeast Atlantic swordfish (Xiphias gladius) off the Bay of Biscay. ICES Journal of Marine Science 63, 1075-1085.

Chapman, E.W., Jørgensen, C., Lutcavage, M.E., 2011. Atlantic bluefin tuna (Thunnus thynnus): a state dependent energy allocation model for growth, maturation, and reproductive investment. Canadian Journal of Fisheries and Aquatic Sciences 68, 19341951.

Chase, B.C., 2002. Differences in diet of Atlantic tuna (Thunnus thynnus) at five seasonal feeding grounds of the New England continental shelf. Fisheries Bulletin 100: 168-180.

Childers, J., Snyder, S., Kohin, S., 2011. Migration and behavior of juvenile North Pacific albacore (Thunnus alalunga). Fisheries Oceanography 20, 157-173.

Christensen, I., 1988. Distribution, movements and abundance of killer whales (Orcinus orca) in Norwegian coastal waters, 1982-1987, based on questionnaire surveys. In: Sigurjónsson and Leatherwood (eds) North Atlantic killer whales. Rit fiskideildar 11, 79-88.

Collette, B.B., McDowell, J.R., Graves, J.E., 2006. Phylogeny of recent billfishes (Xiphiodei). Bulletin of Marine Science, 79, 455-468.

Conway, D.V.P., 1980. The food of larval blue whiting, Micromesistius poutassou (Risso), in the Rockall area. Journal of Fish Biology 16, 709-723.

Coombs, S.H., Conway, D.V.P., Halliday, N.C., 1996. The vertical distribution of eggs and larvae of horse mackerel (Trachurus trachurus). ICES CM 1996, 10 pp.

Coombs, S.H., Morgans, D., Halliday, N.C., 2001. Seasonal and ontogenetic changes in the vertical distribution of eggs and larvae of mackerel (Scomber scombrus L.) and horse mackerel (Trachurus trachurus L.). Fisheries Research 50, 27-40.

Coombs, S.H., Pipe, R.K, Mitchell, C.E. 1981. The vertical distribution of eggs and larvae of blue whiting (Micromesistius poutassou) and mackerel (Scomber scombrus) in the eastern North Atlantic and North Sea. Rapp. P.-v. Réun. Cons. Int. Explor. Mer. 178, 188-195.

Coombs, S.H., Pipe, R.K., Mitchell, C.E., 1979. The vertical distribution of fish eggs and larvae in the eastern North Atlantic, and North sea. ICES Early Life History Symposium, Woods Hole, 2-5 April, 1979, DA:3; 24 pp.

Corten, A., 2002. The role of "conservatism" in herring migrations. Reviews in Fish Biology and Fisheries 11, 339-361

Corten, A., 2000. A possible adaptation of herring feeding migrations to a change in timing of the Calanus finmarchicus season in the eastern North Sea. ICES Journal of Marine Science 57, 1261-1270.

Corten, A., 1999. A proposed mechanism for the Bohuslan herring periods. ICES Journal of Marine Science 56, 207-220.

Courtois, R., Dodson, J.J., 1986. Diet and principal factors influencing the feeding of the larvae of capelin (Mallotus villosus), of smelt (Osmerus mordax) and of herring (Clupea harengus 
harengus) in a partially mixed estuary. Canadian Journal of Fisheries and Aquatic Science 43, 968-979.

Crane, J., 1936. Notes on the biology and ecology of giant tuna Thunnus thynnus, L., observed at Portland, Maine. Zoologica 212, 207-212.

Dahl, K., Kirkegaard, E., 1987. Stomach contents of mackerel, horse mackerel and whiting in the eastern part of the North Sea in July 1985. ICES C.M. 1986/H: 6812 pp.

Dalley E.L., Anderson, J.T., deYoung, B., 2002. Atmospheric forcing, larval drift, and recruitment of capelin (Mallotus villosus). ICES Journal of Marine Science 59, 929-941.

Dalpadado, P., 2002. Inter-specific variations in distribution, abundance and possible life-cycle patterns of Themisto spp. (amphipoda) in the Barents Sea. Polar Biology 25, 656-666.

Dalpadado, P., Ellertsen ,B., Melle, W., Dommasnes, A., 2000. Food and feeding conditions of Norwegian spring-spawning herring (Clupea harengus) through its feeding migrations. ICES Journal of Marine Science 57, 843-857.

Dambacher, J.M., Young, J.W., Olson, R.J., Allain, V., Galván-Magaña, F., Lansdell, M.J., Bocanegra-Castillo, N., Alatorre-Ramírez, V., Cooper, S.P., Duffy, L.M., 2010. Analyzing pelagic food webs leading to top predators in the Pacific Ocean: A graph-theoretic approach. Progress in Oceanography 86, 152-165.

D'Amours, D., Castonguay, M., 1992. Spring migration of Atlantic mackerel, Scomber scombrus, in relation to water temperature through Cabot Strait (Gulf of St. Lawrence). Environmental Biology and Fisheries 34, 393-399.

Darbyson, E., Swain, D.P., Chabot, D., Castonguay, M. 2003. Diel variation in feeding rate and prey composition of herring and mackerel in the southern Gulf of St Lawrence. Journal of Fish Biology 63, 1235-1257.

Davoren, G. K., May, C., Penton, P., Reinfort, B., Record, N., deYoung, B., Rose-Taylor, C., Bell, T., Anderson, J.T., Koen-Alonso, M., Garthe, S., 2008. An Ecosystem-Structured Research Program For Capelin (Mallotus villosus) in the Northwest Atlantic: Overview and Results. Journal of Northwest Atlantic Fisheries Science 39, 35-48.

Dawson, W.A., 1991. Otolith measurement as a method of identifying factors affecting firstyear growth and stock separation of mackerel (Scomber scombrus L.). ICES Journal of Marine Science 47, 303-317.

Dawson, W.A., 1986. Change in western mackerel (Scomber scombrus) spawning stock composition during the spawning season. Journal of the Marine Biological Association UK 66, 367-383.

Dragesund, O., Johannessen, A., Ulltang, Ø., 1997. Variation in migration and abundance of Norwegian spring spawning herring (Clupea harengus L.). Sarsia 82, 97-105.

d'Elbée, J., Castège, I., Hémery, G., Lalanne, Y., Mouchès, C., Pautrizel, F., D'Amico, F. 2009. Variation and temporal patterns in the composition of the surface ichthyoplankton in the southern Bay of Biscay (W. Atlantic). Continental Shelf Research 29, 1136-1144.

De Oliveira, J.A.A., Darby, C.D., Roel, B.A., 2010. A linked separable - ADAPT VPA assessment model for western horse mackerel (Trachurus trachurus), accounting for realized fecundity as a function of fish weight. ICES Journal of Marine Science 67, 916-930.

DFO, 2011. Assessment of capelin in SA $2+$ Div. 3KL in 2010. DFO Can. Sci. Advis. Sec. Sci. Advis. Rep. 2010/090.

Dolgov, A.V. 2002. The role of capelin (Mallotus villosus) in the foodweb of the Barents Sea. ICES Journal of Marine Science, 59: 1034-1045.

Dolgov, A.V., Johannesen, E., Heino, M., Olsen, E., 2009. Trophic ecology of blue whiting in the Barents Sea. ICES Journal of Marine Science 67, 483-493.

Dommasnes, A., Melle, W., Dalpadado, P., Ellertsen, B. 2004. Herring as a major consumer in the Norwegian Sea. ICES Journal of Marine Science 61, 739-751. 
Domokos, R., Seki, M.P., Polovina, J.J., Hawn, D.R., 2007. Oceanographic investigations of the American Samoa albacore (Thunnus alalunga) habitat and longline fishing grounds. Fisheries Oceanography, 16, 555-572

Dragesund, O., Johannessen, A., Ulltang, O., 1997. Variation in migration and abundance of Norwegian spring spawning herring (Clupea harengus L.). Sarsia 82, 97-105.

Drew, K., Die, D.J., Arocha, F., 2006. Understanding vascularization in fin spines of white marlin (Tetrapturus albidus). Bulletin of Marine Science 79, 847-852.

du Buit, M.H., 1996. Diet of hake (Merluccius merluccius) in the Celtic Sea. Fisheries Research 28, 381-394.

Dufour, F., Arrizabalaga, H., Irigoien, X., Santiago, J., 2010. Climate impacts on albacore and bluefin tunas migrations phenology and spatial distribution. Progress in Oceanography 86, 283-290.

Dwyer, K.S., Buren, A., Koen-Alonso, M., 2010. Greenland halibut diet in the Northwest Atlantic from 1978 to 2003 as an indicator of ecosystem change. Journal of Sea Research, 64, 436-445.

Eaton, D.R., 1989. Spawning-stock biomass of scad (Trachurus trachurus L.) to the west of the British Isles, as indicated by egg surveys. J. Cons. Int. Explor. Mer 45, 231-247.

Eden, C., Willebrand, J., 2001. Mechanism of interannual to decadal variability of the North Atlantic circulation. Journal of Climate 14, 2266-2280.

Eggleston, D.B., Bochenek, E.A., 1990. Stomach contents and parasite infestation of school bluefin tuna Thunnus thynnus collected from the Middle Atlantic Bight, Virginia. Fisheries Bulletin 88, 389-395.

Eltink, A.T.G.W., 1987. Changes in age - size distribution and sex ratio during spawning and migration of western mackerel (Scomber scombrus L.). ICES Journal of Marine Science 43, $10-22$.

Erdman, D.S., 2011. The sport fishery for blue marlin off Puerto Rico. Transactions of the American Fisheries Society, 91, 225-227.

Estrada, J.A., Lutcavage, M., Thorrold, S., 2005. Diet and trophic position inferred from stable carbon and nitrogen isotopes of Atlantic bluefin tuna (Thunnus thynnus). Marine Biology 147: 37-45.

FAO, 2010. Statistics and Information Service of the Fisheries and Aquaculture Department. FAO yearbook. Fishery and Aquaculture Statistics 2008. Rome, Italia. 72p.

Fernö, A., Pitcher, T.J., Melle, W., Nøttestad, L., Mackinson, S., Hollingworth, C., Misund, O.A., 1998. The challenge of the herring in the Norwegian Sea: Making optimal collective spatial decisions. Sarsia 83, 149-167.

Flinkman, J., Aro, E., Vuorinen, I., Viitasalo, M. 1998. Changes in northern Baltic zooplankton and herring nutrition from 1980s to 1990s: top-down and bottom-up processes at work. Marine Ecology Progress Series 165, 127-136.

Franco, C., Lago de Lanzo, A., Costas, G., 2009. Seasonal occurrence of mackerel and horse mackerel eggs in the Cantabrian Sea (ICES Division VIIIc) in 2007. WD

Franco, C., Motos, L., Sola, A., Lago de Lanzo, A., 1993. Horse mackerel (Trachurus

trachurus L.) egg distribution and stage I egg production estimates in division VIII b, c, and IXaN in 1988, 1990 and 1992. ICES CM 1993/H:43, 11pp.

Frank, K.T., Petrie, B., Fisher, J.A.D., Leggett, W.C., 2011. Transient dynamics of an altered large marine ecosystem. Nature. doi:10.1038/nature10285. 6p.

Fritches, K.A., Brill, R.W., Warrant, E.J., 2005. Warm eyes provide superior vision in swordfish. Current Biology 15: 55-58.

Fromentin, J.-M., 2009. Lessons from the past: investigating historical data from bluefin tuna fisheries. Fish and Fisheries 10, 197-216. 
Fromentin, J.-M., Fonteneau, A. 2001. Fishing effects and life history traits: a case study comparing tropical versus temperate tunas. Fisheries Research 53, 133-150.

Galuardi, B., Royer, F. Golet, W., Logan, J.M., Neilson, J., Lutcavage, M., 2010. Complex migration routes of Atlantic bluefin tuna questions current population structure paradigm. Canadian Journal of Fisheries and Aquatic Sciences 67, 966-976.

Gislason, A., Astthorsson, A.S. 2002. The food of Norwegian spring-spawning herring in the western Norwegian Sea in relation to the annual cycle of zooplankton. Sarsia 87, 236-247.

Gjøsæter, H., 1998. The population biology and exploitation of capelin (Mallotus villosus) in the Barents Sea. Sarsia, 83, 453-496.

Gjøsæter, H., Bogstad, B., 1998. Effects of the presence of herring (Clupea harengus) on the stock-recruitment relationship of Barents Sea capelin (Mallotus villosus). Fisheries Research $38,57-71$.

Gjøsæter, H., Dalpadado, P., Hassel, A., 2002. Growth of Barents Sea capelin (Mallotus villosus) in relation to zooplankton abundance. ICES Journal of Marine Science 59, 959967.

Goldstein, J., Heppell, S., Cooper, A., Brault, S., Lutcavage, M., 2007. Variability in the reproductive status and body condition of Atlantic bluefin tuna in the Gulf of Maine, 20002002. Marine Biology 151, 2063-2075.

Golet, W.J., Cooper, A.B., Campbell, R., Lutcavage, M., 2007. Decline in condition of Atlantic bluefin tuna in the Gulf of Maine. Fisheries Bulletin 104, 390-395.

Golet, W.J., Galuardi, B., Lutcavage, M., 2011. Distribution of Atlantic bluefin tuna (Thunnus thynnus) in the Gulf of Maine, 1979-2005. Int. Comm. Cons. Atl. Tunas. Coll Vol. Sci. Docs . 116FIX.

Goñi, N., Arregui, I., Lezama, A., Arrizabalaga H., Moreno, G., 2009. Small scale vertical behaviour of juvenile albacore in relation to their biotic environment in the Bay of Biscay. In: Nielsen, J., Arrizabalaga, H., Fragoso, N., Hobday, A., Lutcavage, M., Sibert, J. (eds) Tagging and Tracking of Marine Animals with Electronic Devices pp 51-73.

Goñi, N., Logan' J., Arrizabalaga' H., Jarry, M., Lutcavage, M., 2011. Variability of albacore (Thunnus alalunga) diet in the North-East Atlantic and Mediterranean Sea. Marine Biology 158, 1057-1072.

Goode, G.B., 1884. The fisheries and fishery industries of the United States. In: Natural History of Useful Aquatic Animals. Government Print Office, Washington DC.

Goodyear, C.P., Luo, J., Prince, E.D., Hoolihan, J.P., Snodgrass, D., Orbesen, E.S., Serafy, J.E., 2008. Vertical habitat use of Atlantic blue marlin Makaira nigricans: interaction with pelagic longline gear. Marine Ecology Progress Series 365, 233-245.

Govoni, J.J., Stender, B.W., Pashuk, O., 2000. Distribution of larval swordfish, Xiphias gladius, and probable spawning off the southeastern United States. Fisheries Bulletin 98, 6474.

Graham, J.B., Lowell, R.W., Lai, N.C., Laurs, R.M. 1989. O $_{2}$ tension, swimming velocity, and thermal effects on the metabolic rate of the Pacific albacore, Thunnus alalunga. Experimental Biology, 48, 89-94.

Grave, H., 1981. Food and feeding of mackerel larvae and early juveniles in the North Sea. Rapp. P. -v. Reun. Const. Int. Explor. Mer. 178, 454-459.

Grégoire, F., M. Castonguay. 1989. L'alimentation du maquereau bleu (Scomber scombrus) dans le golfe du Saint-Laurent et sur le plateau néo-écossais, avec une application du test de Mantel. Can. Tech. Rep. Fish. Aquat. Sci. 1673: vi + 23.

Grimm, S.K., 1982. Changes of time and sites of herring (Clupea harengus L.) spawning vs. bottom temperature over the spawning beds in the Georges Bank-Nantucket Shoals area, 1971-1977 seasons. NAFO SCR Documents; 82/09/103. 35p. 
Guichet, R., 1995. The diet of European hake (Merluccius merluccius) in the northern part of the Bay of Biscay. ICES Journal of Marine Science 52, 21-31.

Gutenkunst, R., Newlands, N., Lutcavage, M., Keshett, L., 2007. Inferring resource distributions from Atlantic bluefin tuna movements: an analysis based on net displacement and length of track. Journal of Theoretical Ecology 245, 243-257.

Hamre, J., 1994. Biodiversity and the exploitation of the main fish stocks in the NorwegianBarents Sea ecosystem. Biodiversity Conservation 3, 473-492.

Harden Jones, F.R., 1968. Fish Migration. Edward Arnold Ltd., London 325 pp.

Harden Jones, F.R., 1981. Fish migration: strategy and tactics, in: Aidley, D.J. (ed.), Animal Migration. Cambridge University Press, Cambridge, p. 264.

Harma, C., Brophy, D., Minto, C., and Clarke, M., 2012. The rise and fall of autumn-spawning herring (Clupea harengus L.) in the Celtic Sea between 1959 and 2009: Temporal trends in spawning component diversity. Fisheries Research 121-122, 31-42.

Hassel, A., Skjoldal, H.R., Gjøsæter, H., Loeng, H., Omli, L., 1991. Impact of grazing from capelin (Mallotus villosus) on zooplankton: a case study in the northern Barents Sea in August 1985. In: Proceedings of the Pro Mare Symposium on Polar Marine Biology, Trondheim, Norway, 12-16 May 1990. Edited by Sakshaug, E., C.C.E. Hopkins, and N.A. Oritsland. Polar Res. 10: 371-388.

Hátún, H., Eriksen, C.C., Rhines, P.B., 2007. Buoyant eddies entering the Labrador Sea observed with gliders and altimetry. Journal of Physical Oceanography 37, 2838-2854.

Hátún, H., Payne, M.R., Beaugrand, G., Reid, P.C., Sand $\varnothing$, A.B., Drange, H., Hansen, B., Jacobsen, J.A., Bloch, D., 2009a. Large bio-geographical shifts in the north-eastern Atlantic Ocean: From the subpolar gyre, via plankton, to blue whiting and pilot whales. Progress In Oceanography 80, 149-162.

Hátún, H., Payne, M.R., Jacobsen, J.A., 2009b. The North Atlantic subpolar gyre regulates the spawning distribution of blue whiting (Micromesistius poutassou). Canadian Journal of Fisheries and Aquatic Sciences 66, 759-770.

Hátún, H., Sandø, A. B., Drange, H., Hansen, B., Valdimarsson, H., 2005. Influence of the Atlantic subpolar gyre on the thermohaline circulation. Science 309, 1841-1844.

Heath, M.R., MacLachlan, P. 1986. Studies on herring larvae off the north coast of Scotland. ICES CM (International Council for the Exploration of the Sea. Pelagic Fish Committee); 1986/H:18. 6p.

Heath, M., Henderson, E., and Baird, D., 1988. Vertical distribution of herring larvae in relation to physical mixing and illumination. Marine Ecology Progress Series 47, 211-228

Heino, M., Engelhard, G.H., Godø, O.R., 2008. Migrations and hydrography determine the abundance fluctuations of blue whiting (Micromesistius poutassou) in the Barents Sea. Fisheries Oceanography 17, 153-163.

Henderson, A.C., Dunne, J., 2002. Stomach contents of spiny dogfish Squalus acanthias L. off the west coast of Ireland. Ir. Nat. J. 3, 101-105.

Heinisch, G., Corriero, A., Medina, A., Abascal, F.J., de la Serna, J., Vassallo-Agius, R., Belmonte Rios, A., Garcia, A., de la Gandara, F., Fauvel, C., Bridges, C.R., Mylonas, C.C., Karakulak, S.F., Oray, I., de Metrio, G., Rosenfeld, H., Gordin, H., 2008. Spatial-temporal pattern of bluefin tuna (Thunnus thynnus L. 1758) gonad maturation across the Mediterranean Sea. Marine Biology 154, 623-630.

Hillgruber, N., 2000. Vertical distribution and feeding of larval blue whiting in turbulent waters above Porcupine Bank. Journal of Fish Biology 57, 1290-1311.

Hillgruber, N., Kloppmann, M., 2001. Small-scale patterns in distribution and feeding of Atlantic mackerel (Scomber scombrus L.) larvae in the Celtic Sea with special regard to intra-cohort cannibalism. Helgoland Marine Research 55, 135-149. 
Hillgruber, N., Kloppmann, M., Wahl, E., Von Westernhagen, H., 1997. Feeding of larval blue whiting and atlantic mackerel: A comparison of foraging strategies. Journal of Fish Biology 51, 230-249.

Hjermann, D.Ø., Bogstad, B., Dingsør, G.E., Gjøsæter, H., Ottersen, G., Eikeset, A.M., Stenseth, N.C., 2010. Trophic interactions affecting a key ecosystem component: a multistage analysis of the recruitment of the Barents Sea capelin (Mallotus villosus). Canadian Journal of Fisheries and Aquatic Science 67, 1363-1375.

Hjermann, D.O., Ottersen, G., Stenseth, N.C., 2004. Competition among fishermen and fish causes the collapse of Barents Sea capelin. Proceedings of the national academy of Sciences of the United States of America 101, 11679-11684.

Hjøllo, S.S., Huse, G., Skogen, M.D., Melle, W., 2012. Modelling secondary production in the Norwegian Sea with a fully coupled physical/primary production/individual-based Calanus finmarchicus model system. Marine Biology Research 8, 508-526.

Holliday, N.P., Hughes, S.L., Bacon, S., Beszczynska-Moller, A., Hansen, B., Lavin, A., Loeng, H., Mork, K. A., Osterhus, S., Sherwin, T., Walczowski, W., 2008. Reversal of the 1960s to 1990s freshening trend in the northeast North Atlantic and Nordic Seas. Geophysical Research Letters 35, LO3614.

Holst, J.C., 1992. Cannibalism as a factor regulating year class strength in the Norwegian spring-spawning herring stock. ICES CM 1992/H:14.

Holst, J.C., Dragesund, O., Hamre J., Misund, O.A., Østvedt, O.J., 2002. Fifty years of herring migrations in the Norwegian Sea. ICES Marine Science Symposium 215, 352-360.

Holst, J.C., Iversen, S.A., 1992. Distribution of Norwegian spring-spawning herring and mackerel in the Norwegian sea in late summer, 1991. ICES CM 1992/H:13.

Holst, J.C., Salvanes, A.G.V., Johansen, T., 1997. Feeding, Ichthyophonus sp. infection, distribution and growth history of Norwegian spring-spawning herring in summer. Journal of Fish Biology 50, 652-664.

Holst, J.C., Slotte, A. 1998. Effects of juvenile nursery on geographic spawning distribution in Norwegian spring-spawning herring (Clupea harengus L.). ICES Journal of Marine Science 55, 987-996.

Horrall, R.M., 1981. Behavioral stock-isolating mechanisms in great-lakes fishes with species reference to homing and site imprinting. Canadian Journal of Fisheries and Aquatice Sciences 38, 1481-1496.

Houde, E.D., 2008. Emerging from Hjort's shadow. Journal of the Northwest Altantic Fisheries Society 41, 53-70.

Hughes, K., Johnson, M., Dransfeld, L., Changes in the spatial distribution of spawning activity by northeast Atlantic mackerel in warming seas: 1977-2010. ICES Journal of Marine Science, submitted.

Hunsicker, M.E., Olson, R.J., Essington, T.E., Maunder, M.N., Duffy, L.M., Kitchell, J.F., 2012. Potential top-down control on trophical tunas based on sized-based structure of predator-prey interactions. Marine Ecology Progress Series 445, 263-277.

Huse, G., Ellingsen, I.H., 2008. Capelin migrations and climate change - a modelling analysis. Clim. Change 87, 177-191.

Huse, G., Holst, J.C., Fernö, A., 2010. Establishment of new wintering areas in herring cooccurs with peaks in the 'first time/repeat spawner' ratio. Marine Ecology Progress Series 409, 189-198.

Huse, G., Holst, J.C., Utne, K., Nottestad, L., Melle, W., Slotte, A., Ottersen, G., Fenchel, T., Uiblein, F., 2012. Effects of interactions between fish populations on ecosystem dynamics in the Norwegian Sea - results of the INFERNO project Preface. Marine Biology Research $8,415-419$. 
Huse, G., Johansen, G.O., Gjøsæter, H., Bogstad, B., 2004. Studying spatial and trophic interactions between capelin and cod using individual-based modelling. ICES Journal of Marine Science 61, 1201-1213.

Huse, G., Railsback, S.F., Fernö, A., 2002. Modelling changes in migration pattern of herring: collective behaviour and numerical domination. Journal of Fish Biology 60, 571-582.

Huse, G., Toresen, R., 2000. Juvenile herring prey on Barents Sea capelin larvae. Sarsia 85, 385-391.

Huse, G., Toresen, R. 1996. A comparative study of the feeding habits of herring (Clupea harengus, Clupeidae, L) and Capelin (Mallotus villosus, Osmeridae, Muller) in the Barents Sea. Sarsia 81, 143-153.

Huse, G., Utne, K.R., Fernø, A., 2012. Vertical distribution of herring and blue whiting in the Norwegian Sea. Marine Biology Research 8, 488-501.

Husebø, A., Stenevik, E. K., Slotte, A., Fossum, P., Salthaug, A., Vikebø, F., Aanes, S., Folkvord, A., 2009. Effects of hatching time on year-class strength in Norwegian springspawning herring (Clupea harengus). ICES Journal of Marine Science 66, 1710-1717.

Hunt, G.J., Furness, R.W., 1996. Seabird/fish interactions, with particular reference to seabirds in the north sea. ICES cooperative research report. Nov 1996.

Ibaibarriaga, L., Irigoien, X., Santos, M., Motos, L., Fives, J.M., Franco, C., Lago de Lanzos, A., Acevedo, S., Bernal, M., Bez, N., Eltink, G., Farinha, A., Hammer, C., Iversen, S.A., Milligan, S.P., Reid, D.G., 2007. Egg and larval distributions of seven fish species in northeast Atlantic waters. Fisheries Oceanography 16, 284-293.

ICCAT. 2010a. Report of the 2009 ICCAT Albacore stock assessment session. Collect. Vol. Sci. Pap. ICCAT, 65, 1113-1253

ICCAT. 2010b Report of the 2010 ICCAT Altantic bluefin tuna stock assessement session. $123 \mathrm{pp}$

ICES, 2012. Report of the Working Group on Widely Distributed Stocks (WGWIDE). ICES CM 2012/ACOM:15.931 pp.

ICES, 2011a. Report of the Herring Assessment Working Group for the area South of $62{ }^{\circ} \mathrm{N}$ (HAWG). ICES CM 2011/ACOM:06. 763p

ICES, 2011b. Report of the Working Group on Widely Distributed Stocks (WGWIDE). ICES CM 2011/ACOM:15.624 pp.

ICES, 2010a. Report of the Working Group on Widely Distributed Stocks (WGWIDE). ICES CM 2010/ACOM:15. 612 pp.

ICES, 2010b. Report of the ICES Advisory Committee, 2010 Book 9. 299pp.

ICES. 2010c. Report of the working group of mackerel and horse mackerel egg survyes (WGMEGS). ICES CM 2010/SSGESST:02.

ICES. 2010d. Report of the Working Group on Northeast Atlantic Pelagic Ecosystem Surveys (WGNAPES). ICES CM 2010/SSGESST:20.

ICES. 2008. Report of the working group of mackerel and horse mackerel egg surveys (WGMEGS). ICES CM2008/LCR:09.

ICES, 2007. Report of the Working Group on Northern Pelagic and Blue Whiting Fisheries (WGNPBW) ICES CM 2007/ACFM:29.

ICES, 2005. Report of the study group on multispecies assessment in the North Sea. ICES CM 2005/D: 06.

ICES, 1997. Database report of the stomach sampling project 1991. ICES cooperative research report 219.

Iles, T.D., Sinclair, M., 1982. Atlantic Herring: Stock Discreteness and Abundance. Science 215, 627-633. 
Iles, T.D., Stochasky, J.B. 1985. Drift and current selection, transport and retention, dispersal and homing: a review of concepts and principles relevent to the temporal and spatial organization of marine systems. ICES CM 1985/L:14, 18p.

IPCC. 2007. Contribution of Working Group I to the Fourth Assessment Report of the Intergovernmental Panel on Climate Change. Solomon, S., D. Qin, M. Manning, Z. Chen, M. Marquis, K.B. Averyt, M. Tignor and H.L. Miller (eds.). Cambridge University Press, Cambridge, United Kingdom and New York, NY, USA.

Iversen, S.A., 1977. Spawning, egg production and stock size of mackerel (Scomber scombrus L.) in the North Sea 1968-1975. ICES CM 1977/ H:17.

Iversen, S.A., Skogen, M.D., Svendsen, E., 2002. Availability of horse mackerel (Trachurus trachurus) in the north-eastern North Sea, predicted by the transport of Atlantic water. Fisheries Oceanography 11, 245-250.

Jakobsson, J., Østvedt, O.J., 1999. A review of joint investigations on the distribution of herring in the Norwegian and Iceland Seas 1950-1970. Rit Fiskideildar 16, 209-238.

Jansen, T., Gislason, H., 2011. Temperature affects the timing of spawning and migration of north sea mackerel. Continental Shelf Research 31, 64-72.

Jansen, T., Campbell, A., Kelly, C.J., Hátún, Payne, M., 2012a. Temperature, migration and fisheries of North East Atlantic mackerel (Scomber scombrus) in autumn and winter. PLoS ONE 7(12): e51541. doi:10.1371/journal.pone.0051541

Jansen, T., Kristensen, K., Payne, M., Edwards, M., Schrum, C., Pitois, S., 2012b. Long-term retrospective analysis of mackerel spawning in the North Sea: A new time series and modeling approach to CPR data. PLoS ONE 7, e38758. doi:10.1371/journal.pone.0038758.

Jansen, T. 2013. Pseudocollapse and rebuilding of North Sea mackerel (Scomber scombrus). ICES Journal of Marine Science: doi.10.1093/icesjms/fst148

Jansen, T., Brunel, T., Campbell, A., Clausen, L.A.W. 2013. Spatial segregation within the spawning migration of North Eastern Atlantic Mackerel (Scomber scombrus) as indicated by juvenile growth patterns. PLoS One 8(2): e58114. doi: 10.1371/journal.pone.0058114.

Jansen, T., Gislason, H. 2013. Population structure of Atlantic mackerel (Scomber scombrus). PLoS ONE 8(5): e64744. doi:10.1371/journal.pone.0064744

Jóhannsdóttir, S. and Vilhjálmsson, H., 1999. Fecundity of Icelandic capelin Mallotus villosus (Müller). Rit Fiskideildar 16: 263-270.

Johnsen, E., Godø, O.R., 2007. Diel variations in acoustic recordings of blue whiting (Micromesistius poutassou). ICES Journal of Marine Science 64, 1202-1209.

Junior, T., Vooren, C.M., Lessa, R.P., 2004. Feeding Habits of Four Species of Istiophoridae (Pisces: Perciformes) from Northeastern Brazil. Environmental Biology of Fishes 70, 293304.

Kanwit, J.K., Libby, D.A., 2009. Seasonal movements of Atlantic herring (Clupea harengus): results from a four year tagging study conducted in the Gulf of Maine and Southern New England. Journal of Northwest Atlantic Fisheries Science 40, 29-39.

Karakulak, S., Oray, I., Corriero, A., Deflorio, M., Santamaria, N., Desantis, S., De Metrio, G. 2004. Evidence of a spawning area for the bluefin tuna (Thunnus thynnus L.) in the eastern Mediterranean. Journal of Applied Ichthyology 20, 318-320.

Kelly, K.H., Stevenson, D.K., 1985. Fecundity of Atlantic Herring (Clupea harengus) from Three Spawning Areas in the Western. Gulf of Maine, 1969 and 1982. Journal of Northwest Atlantic Fisheries Science 6, 149-155.

Kieffer, J.D., Colgan, P.W., 1992. The role of learning in fish behaviour. Reviews in Fish Biology and Fisheries 2, 125-143.

Kloppmann, M., Mohn, C., Bartsch, J., 2001. The distribution of blue whiting eggs and larvae on Porcupine Bank in relation to hydrography and currents. Fisheries Research 50, 89-109. 
Kloppmann, M., Hillgruber, N., von Westernhagen, H., 2002. Wind-mixing effects on feeding success and condition of blue whiting larvae in the Porcupine Bank area. Marine Ecology Progress Series 235, 263-277.

Knapp, J., Heinisch, G., Lutcavage, M., 2009. Preliminary results on the reproductive status of Atlantic bluefin tuna sampled in the Gulf of Mexico during spawning season, 2007-2008. ICCAT SCRS/2009/150.

Langøy, H., Nøttestad, L., Skaret, G., Broms, C., Fernö, A., 2012. Overlap in distribution and diets of Atlantic mackerel (Scomber scombrus), Norwegian spring-spawning herring (Clupea harengus) and blue whiting (Micromesistius poutassou) in the Norwegian Sea during late summer. Marine Biology Research, 8, 442-460.

Langøy, H., Nøttestad, L., Skaret, G., Cecilie, T., Broms, A., Fernö, A., 2006. Feeding ecology of Atlantic mackerel (Scomber scombrus) in the Norwegian sea: Diet, prey selection and possible food competition with herring (Clupea harengus) in different water masses. ICES CM 2006/ F:12.

Last, J.M., 1980. The food of twenty species of fish larvae in the west-central North Sea. Fisheries Research Technical Report 60, MAFF Directorate of Fish Research, Lowestoft.

Last, J.M., 1989. The food of herring, Clupea harengus, in the North Sea, 1983-1986. Journal of Fish Biology 34, 489-501.

Laurs, R. M., Dotson, R. C. Dizon A., Jemison, A., 1980. Observations on swimming depth and ocean temperature telemetered from free-swimming albacore. In Proceedings of the 31st Tuna Conference (A. Wild, ed.). Inter.-American Tropical Tuna Commission, La Jolla, California. 33-34.

Laurs, R.M., Lynn, R.J. 1991. North Pacific albacore ecology and oceanography. In: Biology, Oceanography and Fisheries and the North Pacific Transition Zone and Subarctic Frontal Zone. J.A. Wetherall (ed.) Honolulu: NOAA Technical Report NMFS, pp. 69-87.

Lavín, A., Moreno-Ventas, X., Ortiz de Zárate, V., Abaunza, P., Cabanas, J.M., 2007. Environmental variability in the North Atlantic and Iberian waters and its influence on horse mackerel (Trachurus trachurus) and albacore (Thunnus alalunga) dynamics. ICES Journal of Marine Science 64, 425-438.

LeBlanc, C.H., Swain, D., MacDougall, C., Bourque, C., 2010. Assessment of the NAFO Division 4T southern Gulf of St. Lawrence herring stocks in 2009. Canadian Science Advisory Secretariat Research Document 2010/059. 143p.

Lebour, M.V. ,1920. The food of young fish III. Journal of the Marine Biological Association UK 12, 261-324.

Le Gall, J.Y. 1974. Exposé synoptique des données biologiques sur le germon Thunnus alalunga (Bonaterre, 1788) de l'Océan Atlantique. Synopsis FAO sur les pêches, 109: 70 pp.

Leggett, W.C., 1977. Ecology of fish migrations. Annu. Rev. Ecol. Syst. 8, 285-308.

Lehodey, P., Murtugudde, R., Senina, I., 2010a. Bridging the gap from ocean models to population dynamics of large marine predators: A model of mid-trophic functional groups. Progress in Oceanography 84 SI, 69-84.

Lehodey, P., Senina, I., Sibert, J., Bopp, L., Calmettes, B., Hampton, J., Murtugudde, R., 2010b. Preliminary forecasts of Pacific bigeye tuna population trends under the A2 IPCC scenario. Progress in Oceanography 86 SI, 302-315.

Lehodey, P., Senina, I., Murtugudde, R., 2008. A spatial ecosystem and populations dynamics model (SEAPODYM) - Modeling of tuna and tuna-like populations. Progress in Oceanography 78, 304-318.

Letaconnoux, R., 1951. Contribution a l'étude des espéces du genre Trachurus et spécialment du Trachurus trachurus. Mém. Off. Scient. Peches Marit. 15, 1-67. 
Lewis, S., Sherratt, T.N., Hamer, K.C., Harris, M.P., Wanless, S., 2003. Contrasting diet quality of northern gannets Morus bassanus at two colonies. Ardea 91, 167-176.

Lezama-Ochoa, A., Boyra, G., Goñi, N., Arrizabalaga, H., Bertrand, A., 2010. Investigating relationships between albacore tuna (Thunnus alalunga) CPUE and prey distribution in the Bay of Biscay. Progress in Oceanography 86 SI, 105-114.

Lindstrøm, U., Harbitz, A., Haug, T., Pedersen, T., 2000. Foraging behaviour of minke whales (Balaenoptera acutorostrata) in the southern Barents Sea. ICES CM 2000/Q:07, 16p.

Livingston, P.A., 1993. Importance of predation by groundfish, marine mammals and birds on walleye pollock theragra chalcogramma and pacific herring clupea pallasi in the eastern bering sea. Marine Ecology Progress Series 102, 205-215.

Llopiz, J.K., Cowen, R.K., 2008. Precocious, selective and successful feeding of larval billfishes in the oceanic Straits of Florida. Marine Ecology Progress Series 358, 231-244.

Lloris, D., Moreno, T., 1995. Distribution model and association in three pelagic congeneric species (Trachurus spp.) present in the Iberic Mediterranean sea. Scientia Marina 59, 399403.

Lockwood, S.J., 1988. The mackerel - its biology, assessment and the management of a fishery. 181 Pp. ISBN 0-85238-156-5.

Logan, J.M., Rodriguez-Marin, Goñi, N. Barreiro, S., Arrizabalaga, H., Golet, W., Lutcavage, M., 2011. Diet of young Atlantic bluefin tuna (Thunnus thynnus) in eastern and western Atlantic forage grounds. Marine Biology 158, 73-85.

Lucey, S.M., Cook, A.M., Boldt, J.L., Link, J.S., Essington, T.E., Miller, T.J., 2012. Comparative analyses of surplus production dynamics of functional feeding groups across 12 northern hemisphere marine ecosystems. Marine Ecology Progress Series, 459, 219-229.

Lutcavage, M.E, Brill, R.W., Goldstein, J.L., Skomal, G.B., Chase, B.C., Tutein, J., 2000. Movements and behavior of adult North Atlantic bluefin tuna (Thunnus thynnus) in the northwest Atlantic determined using ultrasonic telemetry. Marine Biology 137, 347-358.

Lutcavage, M., Brill, R. Skomal, G., Chase, B., Howey, P., 1999. Results of pop-up satellite tagging on spawning size class fish in the Gulf of Maine. Do North Atlantic bluefin tuna spawn in the Mid-Atlantic. Canadian Journal of Fisheries and Aquatic Sciences 56:173-177.

Macer, C.T. 1977. Some aspects of the biology of the horse mackerel (Trachurus trachurus (L.)) in waters around Britain. Journal of Fish Biology 10, 51-62.

MacKay, K.T., 1973. Aspects of the biology of Atlantic mackerel in ICNAF subarea 4. ICNAF Research Document. 70(3019).

MacKenzie, B.R., Myers, R.A., 2007. The development of the northern European fishery for north Atlantic bluefin tuna Thunnus thynnus during 1900-1950. Fisheries Research 87, 229239.

Magnusson, K.G., Sigurdsson, S.T., Dereksdottir, E.H., 2005. A simulation model for capelin migrations in the North Atlantic. Nonlinear Analysis-Real World Applications 6, 747-771.

Mahé, K., Amara, R., Bryckaert, T., Kacher, M., Brylinski, J.M., 2007. Ontogenetic and spatial variation in the diet of hake (Merluccius merluccius) in the Bay of Biscay and the Celtic Sea. ICES Journal of Marine Science 64, 1210-1219.

Maravelias, C.D., 1997. Trends in abundance and geographic distribution of North Sea herring in relation to environmental factors. Marine Ecology Progress Series 159, 151-164.

Marine Research Institute, 2010. State of marine stock in Icelandic waters 2009/2010; prospects for the quota year 2010/2011. Hafrannsóknir, No. 153. 178 pp.

Markle, G.E., 1974. Distribution of larval swordfish in the northwest Atlantic Ocean. In R. S. Shomura and F. Williams (editors), Proceedings of the International Billfish Symposium, Kailua-Xona, Hawaii, 9-12 Aug., 1972. Part 2. Review and contributed papers. U.S. Dep. Comm. NOAA Tech. Rep. NMFS SSRF-675:252-260. 
Mather, F.J. III, Mason Jr., J.M., Jones, A.C., 1995. Historical document: Life history and fisheries of Atlantic bluefin tuna. NOAA Technical Memorandum NMFS-SEFSC-370.

McQuinn, I.H., 1997. Metapopulations and the Atlantic herring. Reviews in Fish Biology and Fisheries 7, 297-329.

Medina, A., Abascal, F.J. Megina, C., García, A., 2002. Stereological assessment of the reproductive status of female Atlantic northern bluefin tuna during migration to the Mediterranean spawning grounds through the Strait of Gilbraltar. Journal of Fish Biology 60, 203-217.

Mehl, S., 1989. The Northeast Arctic cod stock's consumption of commercially exploited prey species in 1984-1986. Rapp Proc Verb Réun Cons Int l'Exp Mer 188, 185-205.

Mehl, S., Westgård, T., 1983. The diet and consumption of mackerel in the North Sea (a preliminary report). ICES CM 1983/H:34.

Mejuto, J., García, B., 1997. A preliminary analysis of gonadal indices of the swordfish (Xiphias gladius L.) in the Atlantic Ocean. ICCAT Coll. Vol. Sci. Pap. 46 (3), 336- 344.

Mejuto, J., Hoey, J.J., 1991. An approach to stock hypothesis for the swordfish (Xiphias gladius) of the Atlantic Ocean. ICCAT Collective Volume of Scientific Papers 35, 168-178.

Melle, W., Ellertsen, B., Skjoldal, H.R., 2004. Zooplankton: The link to higher trophic levels. In: The Norwegian Sea Ecosystem (Skjoldal, H.R., ed.) Tapir Academic Press, pp. 137-202.

Mendiola, D., Alvarez, P., Cotano, U., De Murguia, A.M., 2007. Early development and growth of the laboratory reared north-east Atlantic mackerel Scomber scombrus L. Journal of Fish Biology 70, 911-933.

Melvin, G.D., Fife, F.J., . Power, M.J., Stephenson, R.L., 1996. The 1996 Review of Georges Bank (5Z) herring stock. DFO Atlantic Fisheries Research Document 96/29. 54.

Melvin, G.D., Martin, R. 2012. Review of environmental factors, condition factor, and fat content of the 4WX herring. Canadian Science Advisory Secretariat Research Document 2012/XXX. 26p.

Melvin, G.D., Stephenson, R.L., 2007. The Dynamics of a Recovering Stock: Georges Bank Herring. ICES Journal of Marine Science 64: 69-82.

Melvin, G.D., Stephenson, R.L., Power, M.J., 2009. Oscillating reproductive strategies of Atlantic herring in response to changing environmental conditions. ICES Journal of Marine Science 66, 1784-1792.

Misund, O.A, Melle, W., Fernö, A., 1997. Migration behaviour of Norwegian spring spawning herring when entering the cold front in the Norwegian Sea. Sarsia 82, 107-112.

Molloy, J., 1984. Density dependent growth in Celtic Sea herring. ICES CM/Pelagic Fish Committee 1984. 13p.

Montes, I., Iriondo, M., Manzano, C., Arrizabalaga, H., Jiménez, E., Pardo, M.A., Goñi, N., Davies, C.A., Estonba, A., 2012. Worldwide genetic structure of albacore Thunnus alalunga revealed by microsatellite DNA markers. Marine Ecology Progress Series 471, 183-191.

Moores, J.A., Winters, G.H., 1984. Growth-patterns in a Newfoundland Atlantic herring (Clupea harengus hargengus) stock. Canadian Journal of Fisheries and Aquatic Sciences 39, 454-461.

Mowbray, F., 2002. Changes in the vertical distribution of capelin (Mallotus villosus) off Newfoundland. ICES Journal of Marine Science. 59: 942-949.

Murawski, S.A., 2010. Rebuilding depleted fish stocks: the good, the bad, and mostly, the ugly. ICES Journal of Marine Science 67, 1830-1840.

Myrberget, S., 1965. Distribution of mackerel eggs and larvae in the Skagerak, 1957-1959. Fisk Oir. Skr. SeI. Havunders. 13, 20-28.

Myers, P. G., 2005. Impact of freshwater from the Canadian Arctic Archipelago on Labrador Sea Water formation. Geophysical Research Letters 32 
Nakashima, B. S., Wheeler, J. P. 2002. Capelin (Mallotus villosus) spawning behaviour in Newfoundland waters - the interaction between beach and demersal spawning. ICES Journal of Marine Science. 59, 909-916.

Neilson, J.D., Smith, S., Royer, F., Paul, SD, Porter, J.M., Lutcavage, M., 2009. Investigations of horizontal movements of Atlantic swordfish using pop-up satellite archival tags. Reviews: Methods and Technologies in Fish Biology and Fisheries 9, 145-159.

Neja, Z., 1995. The stock size and changes in the growth rate of the northwest Atlantic mackerel (Scomber scombrus L.) in 1971-1983. Acta Ichthyol. Pisc.1, 113-120.

Nilsonn, D., 1914. A contribution to the biology of the mackerel. Investigations in swedish waters. Publs Circonst, Cons. Int. Explor. Mer. 69.

Nishikawa, Y., Honma, M., Ueyenagi, S., Kikawa, S. 1985. Average distribution of larvae of oceanic species of scombrid fishes, 1951-81. Contribution of the Far Seas Fisheries Research Laboratory, Fishery Agency of Japan, 236, 1-99.

Nøttestad, L. 2002. Killer whales (Orcinus orca L.) and saithe (Pollachius virens L.) trap herring (Clupea harengus L.) in shallow water by taking advantage of steep bottom topography. ICES CM 2002/N:20. 11p

Nøttestad, L., Doksæter, L., Krafft, B.A., Langård, L., Bernasconi, B., Langøy, H., Axelsen, B.E., Submitted. Prey preference of killer whales (Orcinus orca) in the Norwegian Sea during summer. Can. J. Zool. submitted

Nøttestad L., Giske J., Holst J.C., Huse G., 1999. A length-based hypothesis to explain feeding migrations in pelagic fish. Canadian Journal of Fisheries and Aquatic Sciences 56 (Supplement I), 26-34.

Nøttestad, L., Jacobsen, J.A., 2009. Coordinated norwegian-faroese ecosystem survey with M/V "Libas", M/V "Eros", and M/V "Finnur fríði" in the Norwegian sea, 15 july- 6 august 2009. ICES CM 2009/ACOM:12:WD.

Nøttestad, L., Jacobsen, J.A., Sveinbjørnsson et al. 2010. Cruise report from the coordinated ecosystem survey with M/V "libas" and M/V "brennholm", M/V "finnur fridi" and R/V "arni fridriksson" in the Norwegian sea and surrounding waters, 9 july- 20 august 2010.

Nøttestad, L., Misund, O.A., Melle, W., Ulvestad, B.K.H., Orvik, K.A., 2007. Herring at the Arctic front: influence of temperature and prey on their spatio-temporal distribution and migration. Marine Ecology - an Evolutionary Perspective 28:123-133.

Olafsdottir, D., Ingimundardottir, T., 2000. Preliminary report on experimental fisheries and biological research on bluefin tuna (Thunnus thynnus) within the Iceland EEZ, 1996-1998. Collective volume of scientific papers ICCAT, Madrid, Vol. 91: 827-838.

Olaso, I., Cendrero, O., Abaunza, P., 1999. The diet of the horse mackerel, Trachurus trachurus (Linnaeus 1758), in the Cantabrian Sea (north of Spain). Journal of Applied Ichthyology $15,193-198$.

Olaso, I., Gutiérrez, J.L., Villamor, B., Carrera, P., Valdés, L., Abaunza, P., 2005. Seasonal changes in the north-eastern Atlantic mackerel diet (Scomber scombrus) in the north of Spain (ICES Division VIIIc). Journal of the Marine Biological Association of the UK 85, 415-418.

Olla, B.L., Bejda, A.J., Studholme, A.L., 1976. Swimming speeds of Atlantic mackerel Scomber scombrus under labratory conditions relation to capture by trawling. Int Comm Northwest Atl Fish (ICNAF) Res Doc. 76/XII/143.

Olla, B.L., Studhome, A.L., Bejda, A.J., Samet, C., Martin, A.D., 1975. The effect of temperature on the behaviour of marine fishes: A comparison among Atlantic mackerel Scomber scombrus, bluefish Pomatomus saltatrix and tautog Tautoga onitis. In: Combined Effects of Radioactive Chemical and Thermal Releases to the Environment, International Atomic Energy Agency, Vienna, 299-308. 
Olsen, E., Holst, J.C., 2001. A note on common minke whale (Balaenoptera acutorostrata). Journal of Cetacean Research and Management, 2, 179-183.

Orbesen, E.S., Hoolihan, J.P., Serafy, J.E., Snodgrass, D., Peel, E.M., Prince, E.D., 2008. Transboundary movement of Atlantic istiophorid billfishes among international and U.S. domestic management areas Inferred from mark-recapture studies. Marine Fisheries Review 70, 14-23.

Orlova, E.L., Rudneva, G.B., Renaud, P.E., Eiane, K., Savinov, V., Yurko, A.S., 2010. Climate impacts on feeding and condition of capelin Mallotus villosus in the Barents Sea: evidence and mechanisms from a 30 year data set. Aquatic Biology 10, 105-118.

Ortiz de Zarate, V., Cort, J.L. 1998. Albacore (Thunnus alalunga, Bonnaterre) stock structure in the Atlantic Ocean, as inferred from distribution and migration patterns. Proceedings of the ICCAT Tuna Symposium (Beckett, J.E. ed.), Vol. 1, 251-260.

Ortiz de Zarate, V., 1987. Datos sobre la alimentacion del atun blanco (Thunnus alalunga B.) juvenil capturado en el Golfo de Vizcaya. Col Vol Sci Pap ICCAT 26(2):243-247

Óskarsson, G.J., 2005. Pre-spawning Factors and Recruitment Variation in Atlantic Herring (Clupeidae; Clupea harengus, L.): A Comparative Approach. PhD Thesis, Halifax, Canada: Oceanography Department, Dalhousie University, 251p.

Óskarsson, G.J. 2008. Variation in body condition, fat content and growth rate of Icelandic summer-spawning herring Clupea harengus L. Journal of Fish Biology 72, 2655-2676.

Óskarsson, G.J., Taggart, C.T., 2010. Variation in reproductive potential and influence on Icelandic herring recruitment. Fisheries Oceanography 19, 412-426.

Óskarsson, G.J., Taggart, C.T., 2006. Fecundity variation in Icelandic summer-spawning herring and implications for reproductive potential. ICES Journal of Marine Science 63, 493-503.

Oskarsson, G.J., Gudmundsdottir, A., Sigurdsson, T., 2009. Variation in spatial distribution and migration of Icelandic summer-spawning herring. ICES Journal of Marine Science 66, 1762-1767.

Óskarsson, G.J., Kjesbu, O.S., Slotte, A. 2002. Predictions of realised fecundity and spawning time in Norwegian-spring spawning herring (Clupea harengus): possible implications for subsequent recruitment. Journal of Sea Research 48, 59-79.

Østvedt, O.J., 1965. The migration of the Norwegian herring to Icelandic waters and the environmental conditions in May-June. Fisk dir Skr (Ser HavUnders) 13:29-xxx

Overholtz, W.J., 1989. Density-dependent growth in the northwest atlantic stock of atlantic mackerel (Scomber scombrus). Journal of Northwest Atlantic Fisheries Science 2, 115-121.

Overholtz, W.J., Armstrong, R.S., Mountain, D.G., Tercerio, M., 1991. Factors influencing spring distribution, availability, and recreational catch of Atlantic mackerel (Scomber scombrus) in the middle Atlantic and southern new England regions. Report NTIS Order no. : PB92-160209/GAR. NOAA-TM-NMFS-F/NEC-85.

Overholtz, W.J., Jacobson, L.D., Link, J.S., 2008. An Ecosystem Approach for Assessment Advice and Biological Reference Points for the Gulf of Maine-Georges Bank Atlantic Herring Complex. North American Journal of Fisheries Management 28, 247-257.

Overholtz, W.J., Jacobson, L.J., Melvin, G.D., Cieri, M., Power, M.J., Libby, D. Clark, K., 2004. Stock assessment of the Gulf of Maine-Georges Bank herring stock complex, 19592002. Northeast Fisheries Science Center, Reference Document 04-06. 300p.

Overholtz, W.J., Link, J.S., 2007. Consumption impacts by marine mammals, fish, and seabirds on the Gulf of Maine-Georges Bank Atlantic herring (Clupea harengus) complex during the years 1977-2002. ICES Journal of Marine Science 64, 83-96.

Overholtz, W.J., Link, J.S., Suslowicz, L.E., 2000. Consumption of important pelagic fish and squid by predatory fish in the northeastern USA shelf ecosystem with some fishery comparisons. ICES Journal of Marine Science 4, 1147-1159. 
Pálsson, O., H. Valdimarsson, H., Olafsdottir, S.R., Gudfinnsson, H.G., Gislason, A., Petursdottir, H., Sveinbjornsson, S., 2008. Ecosystem properties of the Iceland Sea and capelin ecology during summer. Hafrannsoknir, 145, 54-59.

Parrish, J.K., 1993. Comparison of the hunting behavior of four piscine predators attacking schooling prey. Ethology 95, 233-246.

Payne, M. R., Hatfield, E. M. C., Dickey-Collas, M., Falkenhaug, T., Gallego, A., Groger, J., Licandro, P., et al., 2008. Recruitment in a changing environment: the 2000s North Sea herring recruitment failure. ICES Journal of Marine Science 66, 272-277.

Payne, M. R., 2010. Mind the gaps: a state-space model for analysing the dynamics of North Sea herring spawning components. ICES Journal of Marine Science 67, 1939-1947.

Payne, M.R., Egan, A., Fässler, S.M.M., Hátún, H., Holst, J.C., Jacobsen, J.A., Slotte, A., Loeng, H., 2012. The rise and fall of the NE Atlantic blue whiting (Micromesistus poutassou). Marine Biology Research, 8, 475-487.

Peck, M.A., Kühn, W., Hinrichsen, H.-H., and Pohlmann, T., 2009. Inter-annual and interspecific differences in the drift of fish eggs and yolksac larvae in the North Sea: A biophysical modeling approach. Scientia Marina 73 (S1), 23-36.

Pepin, P., Koslow, J.A., Pearre, S., 1988. Laboratory study of foraging by atlantic mackerel, Scomber scombrus, on natural zooplankton assemblages. Canadian Journal of Fisheries and Aquatic Sciences 45, 879-887.

Pepin, P., Pearre, S., Koslow, J.A., 1987. Predation on larval fish by atlantic mackerel, Scomber scomburs, with a comparison of predation by zooplankton. Canadian Journal of Fisheries and Aquatic Sciences 44, 2012-2017.

Persohn, C., 2009. Sensibilité des populations de poissons aux changements globaux en fonction de leurs traits d'histoire de vie étudiée par une approche empirique. Ph.D. Université de Bretagne Occidentale, 198pp.

Persohn, C., Lorance, P., Trenkel, V.M., 2009. Habitat preferences of selected demersal fish species in the Bay of Biscay and Celtic Sea, North-East Atlantic. Fisheries Oceanography $18,268-285$.

Petitgas, P., Alheit, J., Beare, D., Bernal, M., Casini, M., Clarke, M., Cotano, U., DickeyCollas, M., Dransfeld, L., Harma, C., Heino, M., Masse, J., Mollmann, C., Nogueira, E., Reid, D., Silva, A., Skaret, G., Slotte, A., Stratoudakis, Y., Uriarte, A., Voss, R., 2010. Lifecycle spatial patterns of small pelagic fish in the Northeast Atlantic. ICES cooperative research report 306. $94 \mathrm{p}$.

Pinnegar, J.K., Trenkel, V.M., Tidd, A.N., Dawson, W.A., du Buit, M.-H., 2003. Does diet in Celtic Sea fishes reflet prey availability? Journal of Fish Biology 63 (Supplement A), 197212.

Pitcher, T.J., Misund, O.A., Fernö, A., Totland, B., Melle, V., 1996. Adaptive behaviour of herring schools in the Norwegian Sea as revealed by high-resolution sonar. ICES Journal of Marine Science, 53: 449-452.

Planque, B., Fromentin, J.-M., Cury, P., Drinkwater, K.F., Jennings, S., Perry, R.I., Kifani, S., 2010. How does fishing alter marine populations and ecosystems sensitivity to climate? Journal of Marine Systems 79, 403-417. NAFO Divisions 4VWX. DFO Can. Sci. Advis. Sec. Res. Doc. 2012/084. iv + 98 p. Available at: http://www.dfo-mpo.gc.ca/csas-sccs/Publications/ResDocsDocRech/2012/2012_084-eng.html 
Power, M.J., Knox, D., Melvin, G.D., 2011. 2010 Evaluation of 4VWX Herring. DFO Can. Sci. Advis. Sec. Res. Doc. 2010/112: vi + 124p.

Power, M.J., Fife, F.J., Knox, D., Melvin, G.D., 2010. 2009 Evaluation of 4VWX Herring. Canadian Science Advisory Secretariat Research Document 2010/111. 89p

Preciado, I., Velasco, F., Olaso, I., 2008. The role of pelagic fish as forage for the demersal fish community in the southern Bay of Biscay. Journal of Marine Systems 72, 407-417.

Prince, E.D., Luo, J., Phillip Goodyear, C., Hoolihan, J.P., Snodgrass, D., Orbesen, E.S., Serafy, J.E., Ortiz, M., Schirripa, M.J., 2010. Ocean scale hypoxia-based habitat compression of Atlantic istiophorid billfishes. Fisheries Oceanography 19, 448-462.

Prokopchuk, I., Sentyabov, E., 2006. Diets of herring, mackerel, and blue whiting in the Norwegian Sea in relation to Calanus finmarchicus distribution and temperature conditions. ICES Journal of Marine Science 63, 117-127.

Punzon, A., Villamor, B., 2009. Does the timing of the spawning migration change for the southern component of the northeast Atalantic mackerel (Scomber scombrus, L.1758)? An approximation using fishery analyses. Continental Shelf Research 29, 1195-1204.

Purcell, J.E., 1990. Soft-bodied zooplankton predators and competitors of larval herring (Clupea harengus pallasi) at herring spawning grounds in british columbia. Canandian Journal of Fisheries and Aquatic Sciences 47, 505-515.

Pusineri, C., Chancollon, O., Ringelstein, J., Ridoux, V. 2008. Feeding niche segregation among the Northeast Atlantic community of oceanic top predators. Marine Ecology Progress Series 361, 21-34.

Pusineri, C., Vasseur, Y., Hassani, S., Meynier, L., Spitz, J., Ridoux, V., 2005. Food and feeding ecology of juvenile albacore, Thunnus alalunga, off the Bay of Biscay: a case study. ICES Journal of Marine Science 62,116-122.

Quinlan, J.A., Lough, R.G., Michaels, W., Fogarty, M., Buckley, L.J., Manning, J.P., Durbin, E., Runge, J.A., Werner, F.E., 2000. Examining the potential effects of vertebrate predation on Georges Bank larval cod: a modeling study for the 1995 field season. ICES CM 2000/N:25.

Ravier, C., Fromentin, J.M., 2004. Are the long-term fluctuations in Atlantic bluefin tuna (Thunnus thynnus) population related to environmental changes? Fisheries Oceanography 13, 145-160.

Read, A.J., Brownstein, C.R., 2003. Considering other consumers: fisheries, predators, and Atlantic herring in the Gulf of Maine. Conservation Ecology 7(1): 2. [online] URL: http://www.consecol.org/vol7/iss1/art2/

Reid, P.C., Borges, M.F., Svendsen, E., 2001. A regime shift in the North Sea circa 1988 linked to changes in the North Sea horse mackerel fishery. Fisheries Research 50, 163-171.

Reid, D.G., Eltink, A., Kelly, C.J., 2003. Inferences on the changes in pattern in the prespawning migration of the western mackerel (Scomber scombrus) from commercial vessel data. ICES CM 2003/Q:19.

Reid, D.G., Eltink, A., Kelly, C.J., Clark, M., 2006. Long-term changes in the pattern of the prespawning migration of the western mackerel (Scomber scombrus) since 1975, using commercial vessel data. ICES CM 2006/B:14.

Reid, D.G., Turrell, W.R., Walsh, M., Corten, A., 1997. Cross-shelf processes north of scotland in relation to the southerly migration of western mackerel. ICES Journal of Marine Science 54, 168-178.

Reid, D.G., Walsh, M., Turrell, W.R., 2001b. Hydrography and mackerel distribution on the shelf edge west of the Norwegian deeps. Fisheries Research 50, 141-150. 
Restrepo, V.R., Diaz, G.A., Walter, J.F., Neilson, J.D., Campana, S.E., Secor, D., Wingate, R.L., 2010. Updated estimate of the growth curve of Western Atlantic bluefin tuna. Aquatic Living Resources 23, 335-342.

Richards, W.J., 1969. Distribution and relative apparent abundance of larval tunas collected in the tropical Atlantic during Equalant surveys I and II. Proc. Symp. Oceanogr. Fish. Resourc. Trop. Atl.-Rev. Contrib. Pap. UNESCO, Paris, Pap. 25: 289-315.

Richards, W.J., 1984.. Kinds and abundances of fish larvae in the Caribbean Sea and adjacent areas. U.S. Dep. Commer., NOAA Technical Report NMFS SSRF 776: 54 p.

Richardson, D.E., Cowen, R.K., Prince, E.D., Sponaugle, S., 2009. Importance of the Straits of Florida spawning ground to Atlantic sailfish (Istiophorus platypterus) and blue marlin (Makaira nigricans). Fisheries Oceanography 18, 402-418.

Ringuette, M., Castonguay, M., Runge, J.A., Grégoire, F., 2002. Atlantic mackerel (Scomber scombrus) recruitment fluctuations in relation to copepod production and juvenile growth. Canadian Journal of Fisheries and Aquatic Sciences 4, 646-656.

Robert, D., Castonguay, M., Fortier, L., 2009. Effects of preferred prey density and temperature on feeding success and recent growth in larval mackerel of the southern Gulf of St. Lawrence. Marine Ecology Progress Series 377, 227-237.

Robert, D., Castonguay, M., Fortier, L., 2008. Effects of intra- and inter-annual variability in prey field on the feeding selectivity of larval Atlantic mackerel (Scomber scombrus). Journal of Plankton Research 30, 673-688.

Robert, D., Castonguay, M., Fortier, L., 2007. Early growth and recruitment in Atlantic mackerel Scomber scombrus: Discriminating the effects of fast growth and selection for fast growth. Marine Ecology Progress Series 337, 209-219.

Rooker, J.R., Secor, D.H., De Metrio, G., Schloesser, R., Block, B.A., Neilson, J.D., 2008. Natal homing and connectivity in Atlantic bluefin tuna populations. Science 322, 742-744.

Rooker, J.R., Alvarado Bremer, J.R., Block, B.A., Dewar, H., De Metrio, G., Corriero, A., Kraus, R.T., Prince, E.D., Rodriguez-Marin, E., Secor, D.H., 2007. Life history and stock structure of Atlantic bluefin tuna (Thunnus thynnus). Reviews in Fisheries Science 15, 265310.

Röpke, A., 1989. Small-scale vertical distribution of ichthyoplankton in the celtic sea in April 1986. Meeresforsch. 32, 192-203.

Rose, G.A., O'Driscoll, R.L., 2002. Capelin are good for cod: can the northern stock rebuild without them? ICES Journal of Marine Science 59, 1018-1026.

Rouyer, T., Fromentin, J.-M., Stenseth, N.C., 2010. Environmental noise affects the fluctuations of Atlantic large pelagics. Progress in Oceanography 86 SI, 267-275.

Sagarminaga, Y, Arrizabalaga, H., 2010. Spatio-temporal distribution of albacore (Thunnus alalunga) catches in the northeastern Atlantic: relationship with the thermal environment. Fisheries Oceanography 19, 121-134.

Santiago, J., Arrizabalaga, H., 2005. An integrated growth study for North Atlantic albacore (Thunnus alalunga Bonn. 1788). ICES Journal of Marine Science 62, 740-749.

Santos, A.M.P., Borges, M.F., Groom, S., 2001. Sardine and horse mackerel recruitment and upwelling off Portugal. ICES Journal of Marine Science 58, 589-596.

Sara, G., Sara, R., 2007. Feeding habits and trophic levels of bluefin tuna Thunnus thynnus of different size classes in the Mediterranean Sea. Journal of Applied Ichthyology 23, 122-127.

Schick, R.S., Goldstein, J., Lutcavage, M.E., 2004. Bluefin tuna (Thunnus thynnus) distribution in relation to sea surface temperature fronts in the Gulf of Maine (1994-96). Fisheries Oceanography 13, 225-238. 
Schick, R.S., Lutcavage, M.E., 2009. Inclusion of prey data improves prediction of bluefin tuna (Thunnus thynnus) distribution. Fisheries Oceanography 18, 77-81.

Scott, W.B., Scott, M.G., 1988. Atlantic fishes of Canada. University of Toronto Press, Toronto. 608 pp.

Segers, F.H.I.D, Dickey-Collas, M., Rijnsdorp, A.D., 2007. Prey selection by North Sea herring (Clupea harengus), with special reference to fish eggs. ICES Journal of Marine Science 64, 60-68.

Seki, M.P., Lumpkin, R., Flament, P., 2002. Hawaii cyclonic eddies and blue marlin catches: the case study of the 1995 Hawaiian International Billfish Tournament. Journal of Oceanography 58, 739-745.

Senina I., Sibert J., Lehodey P. 2008. Parameter estimation for basin-scale ecosystem-linked population models of large pelagic predators: application to skipjack tuna. Progress in Oceanography, 78, 319-335.

Sette, O.E., 1943. Biology of Atlantic mackerel (Scomber scombrus) of North America. Part I: Early life history of the fish. Fish Bull Fish Wildl Serv. 50, 149-237.

Sette, O.E., 1950. Biology of Atlantic mackerel (Scomber scombrus) of North America. Part II: Migration and habits. Fish Bull Fish Wildl Serv. 51(49): 249-258.

Sharp G.D., Vlymen, W.J. 1978. The relationship between heat generation, conservation, and the swimming energetics of tunas. In: GD Sharp and AW Dizon(eds) The Physiological Ecology of Tunas. Academic Press, New York, USA, pp. 213-232.

Sherwood, G.D., Rideout, R.M., Fudge, S.B., Rose, G.A., 2007. Influence of diet on growth, condition and reproductive capacity in Newfoundland and Labrador cod (Gadus morhua): Insights from stable carbon isotopes $\left(\square{ }^{13} \mathrm{C}\right)$. Deep Sea Research II 54: 2794-2809.

Shimose, T., Shono, H., Yokawa, K., Saito, H., Tachihara, K., 2006. Food and feeding habits of blue marlin, Makaira nigricans, around Yonaguni Island, southwestern Japan. Bulletin of Marine Science, 79, 761-775.

Sigurjónsson, J., Víkingsson, G.A. 1997. Seasonal abundance of and estimated food consumption by cetaceans in Icelandic and adjacent waters. Journal of Northwest Atlantic Fishery Science 22, 271-287.

Simmonds, E.J., Portilla, E., Skagen, D., Beare, D., Reid, D.G., 2010. Investigating agreement between different data sources using Bayesian state-space models: an application to estimating NE Atlantic mackerel catch and stock abundance. ICES Journal of Marine Science 67, 1138-1153.

Sinclair, M., Iles, T.D., 1981. Oceanographic and Atlantic herring life history distributions of interest in relation to the herring stock problem in the Georges Bank, Gulf of Maine and Bay of Fundy area 1981. NAFO SCR documents; 81/09/126. 26p.

Sinclair, M., Sinclair, A., Iles, T.D. 1982. Growth and maturation of southwest Nova-Scotial herring (Clupea harengus harengus). Canadian Journal of Fisheries and Aquatic Sciences 39, 288-295.

Skjoldal, H.R., Gjøsæter, H., Loeng, H., 1992. The Barents Sea ecosystem in the 1980s: ocean climate, plankton and capelin growth. ICES Marine Science Symposium 195, 278-290.

Skogen, M., Monstad, T., Svendsen, E., 1999. A possible separation between a northern and a southern stock of the northeast Atlantic blue whiting. Fisheries research 41, 119-131.

Slotte, A., 1999. Effects of fish length and condition on spawning migration in Norwegian spring spawning herring (Clupea harengus L.). Sarsia 84, 111-127.

Southward, A.J., Barrett, R.L., 1983. Observations on the vertical distribution of zooplankton, including post-larval teleosts, off Plymouth in the presence of a thermocline and a chlorophyll-dense layer. Journal of Plankton Research 5, 599-618. 
Speirs, D.C., Gurney, W.S.C., Heath, M.R., Horbelt, W., Wood, S.N., 2006. Ocean-scale modelling of the distribution, abundance, and seasonal dynamics of the copepod Calanus finmarchicus. Marine Ecology Progress Series 313, 173-192.

Speirs, D.C., Gurney, W.S.C., Heath, M.R., Wood, S.N., 2005. Modelling the basin-scale demography of Calanus finmarchicus in the North East Atlantic. Fisheries Oceanography 14, 333-358.

Spitz, J., Cherel, Y. Bertin, S., Kiszka, J., Dewez, A., Ridoux, V., 2011. Prey preferences among the community of deep-diving odontocetes from the Bay of Biscay, Northeast Atlantic. Deep-Sea Research Part 1: Oceanographic Research Papers 58, $273-282$.

Sponaugle, S., Denit, K., L., Luthy, S.A., Serafy, J.E., Cowen, R.K., 2005. Growth variation in larval Makaira nigricans. Journal of Fish Biology 66, 822-835.

Stobo, W.T., Fowler, G.M., 2009. Herring tagging in the vicinity of the Scotian Shelf and Gulf of St. Lawrence by the Maritimes Region, 1973-1982. Canadian Technical Report of Fisheries and Aquatic Sciences 2851.69p.

Su, N.-J., Sun, C.-L., Punt, A.E., Yeh, S.-Z., DiNardo, G., 2011. Modelling the impacts of environmental variation on the distribution of blue marlin, Makaira nigricans, in the Pacific Ocean. ICES Journal of Marine Science, 68, 1072-1080.

Sutherland, W.J. 2006. Predicting the ecological consequences of environmental change: a review of the methods. Journal of Applied Ecology, 43, 599-616.

Sun, C.-L., Chang, Y.-J., Tszeng, C.-C., Yeh, S.-Z., Su, N.-J., 2009. Reproductive biology of blue marlin (Makaira nigricans) in the western Pacific Ocean. Fishery Bulletin (Seattle), 107, 420-432.

Svendsen, E., Skogen, S., Monstad, T., Coombs, S.H., 1996. Modelling the variability of the drift of blue whiting larvae and its possible importance for recruitment. ICES CM 1996/S:31.

Taggart, C. T., Leggett, W. C., 1987. Wind-forced hydrodynamics and their interaction with larval fish and plankton abundance: a time-series of physical-biological data. Canadian Journal of Fisheries and Aquatic Sciences, 44: 438-451.

Taning, A.V., 1955. On the breeding areas of the swordfish (Xiphias). Deep Sea Research Suppl. 3, 438-450.

Tereshchenko, E.S., 2002. The dynamics of population fecundity in Barents Sea capelin. ICES Journal of Marine Science 59, 976-982.

Tibbo, S.N., Lauzier, L.M. 1969. Larval swordfish (Xiphias gladius) from three localities in the western Atlantic. J. Fish. Res. Board Can. 26: 3248-3251.

Tiews, K., 1978. On the disappearance of bluefin tuna in the North Sea and its ecological implications for herring and mackerel. Rapp. P.-v. Reun. Cons. int. Explor. Mer. 172, 301309.

Tjelmeland, S., Bogstad, B., 1998. MULTSPEC - a review of a multispecies modelling project for the Barents Sea. Fisheries Research 37, 127-142.

Toresen, R., 1991. Predation on the eggs of norwegian spring-spawning herring (Clupea harengus L.) on a spawning ground on the west coast of Norway. ICES Journal of Marine Science 48, 15-21.

Toresen, R., 1990. Long-term changes in growth of Norwegian spring-spawning herring. J. Cons. int. Explor. Mer 47, 48-56.

Toresen, R., Østvedt, O.J. 2000. Variation in abundance of Norwegian spring-spawning herring (Clupea harengus, Clupeidae) throughout the 20th century and the influence of climatic conditions. Fish and Fisheries, 1, 231-256.

TRAC. 2009. Gulf of Maine-Georges Bank herring stock complex. Transboundary Resources Assessment Committee Status Report 2009/04. 6p. 
Trenkel, V.M., Pinnegar, J.K., Dawson, W.A., du Buit, M.H., Tidd, A.N., 2005. Spatial and temporal structure of predator-prey relationships in the Celtic Sea fish community. Marine Ecology Progress Series 299, 257-268.

Tsou, T.S., Collie, J.S., 2001. Predation-mediated recruitment in the Georges Bank fish community. ICES Journal of Marine Science 58, 994-1001.

Ushakov, N.G., Prozorkevich, D.V. 2002. The Barents Sea capelin - a review of trophic interrelations and fisheries. ICES Journal of Marine Science, 59: 1046-1052.

Uriarte, A., Lucio, P., 1996. Results of a tagging survey of mackerel in the Bay of Biscay in 1994. ICES CM 1996/S:10.

Uriarte, A., Alvarez, P., Iversen, S., Molloy, J., Villamor, B., Martins, M.M., Myklevoll, S., 2001. Spatial pattern of migration and recruitment of north east Atlantic mackerel. ICES CM 2001/O:17.

Utne, K.R., Hjøllo, S.S., Huse, G., Skogen, M., 2012a. Estimating consumption of Calanus finmarchicus by planktivorous fish in the Norwegian Sea estimated fromusing a fully coupled 3D model system. Marine Biological Research, 8, 527-547.

Utne, K.R., Huse, G., Ottersen, G., Holst, J.C., Zabavnikov, V., Jacobsen, J.A., Óskarsson, G.J., Nøttestad, L., 2012b. Horizontal distribution and overlap of planktivorous fish stocks in the Norwegian Sea during summers 1995-2006. Marine Biological Research, 8, 420-441.

Utne, K.R., Huse, G., 2012. Estimating the horizontal and temporal overlap of pelagic fish distribution in the Norwegian Sea using individual-based modelling. Mar. Biol. Res. 8, 548567.

van Damme, C.J.G., Dickey-Collas, M., Rijnsdorp, A.D., Kjesbuc, O.S., 2009. Fecundity, atresia, and spawning strategies of Atlantic herring (Clupea harengus). Canadian Journal of Fisheries and Aquatic Sciences 66, 2130-2141.

Vilhjálmsson, H., 1994. The Icelandic capelin stock. Rit Fiskideildar 13, 1-281.

Vilhjalmsson, H., 1997. Climatic variations and some examples of their effects on the marine ecology of Icelandic and Greenland waters, in particular during the present century. Rit Fiskideildar 15, 9-29.

Vilhjálmsson, H., 2002. Capelin (Mallotus villosus) in the Iceland-East Greeland-Jan Mayen ecosystem. ICES Journal of Marine Science 59, 870-883.

Vikebø, F.B., Huseb $\varnothing$, A., Slotte, A., Stenevik, E.K., Lien, V.S. 2010. Effect of hatching date, vertical distribution, and interannual variation in physical forcing on northward displacement and temperature conditions of Norwegian spring-spawning herring larvae. ICES Journal of Marine Science 67, 1948-1956.

Villamor, B., Abaunza, P., Farina, A.C., 2004. Growth variability of mackerel (Scomber scombrus) off north and northwest spain and a comparative review of the growth patterns in the northeast Atlantic. Fisheries Research 1, 107-121.

Walsh, M., Martin, J.H.A., 1986. Recent changes in the distribution and migration of the western mackerel stock in relation to hydrographic changes. ICES CM 1986/H:17.

Walsh, M., Reid, D.G., Turrell, W.R., 1995. Understanding mackerel migration off Scotland tracking with echosounders and commercial data, and including environmental correlates and behavior. ICES Journal of Marine Science 52, 925-939.

Ware, D.M., Lambert, T.C., 1985. Early life history of Atlantic mackerel (Scomber scombrus) in the southern Gulf of St. Lawrence. Canadian Journal of Fisheries and Aquatic Science. 42, 577-592.

Was, A., Gosling, E., McCrann, K., Mork, J., 2008. Evidence for population structuring of blue whiting (Micromesistius poutassou) in the Northeast Atlantic. ICES Journal of Marine Science 65, 216-225. 
Wiborg, K.F., 1955. Zooplankton in relation to hydrography in the Norwegian Sea. Report on Norwegian Fishery and Marine Investigations 1-66.

Wheeler, J.P., Winters, G.H., 1984. Migration and stock relationships of east and south east Newfoundland herring (Clupea harengus) as shown by tagging. Journal of Northwest Atlantic Fishery Science 5, 121-129.

Wheeler, J.P., Purchase, C.F., Macdonald, P.D.M., Fill, R., Jacks, L., Wang, H., Ye, C., 2009. Temporal changes in maturation, mean length-at-age, and condition of spring spawning Atlantic herring (Clupea harengus) in Newfoundland waters. ICES Journal of Marine Science 66, 1800-1807.

Wheeler, J.P., Squires, B., Williams, P. 2010. An assessment framework and review of Newfoundland east and south coast herring stocks to the spring of 2009. Canadian Science Advisory Secretariat Research Document 2010/020. 123p.

Wheeler, J.P., Winters, G. H., 1984. Summary of herring tagging experiments conducted along the east and southeast coasts of Newfoundland, 1974-81. Canadian Data Report of Fisheries and Aquatic Sciences, 439. 22p.

Wilson, C.A., Dean, J.M., Prince, E.D., Lee, D.W., 1991. An examination of sexual dimorphism in Atlantic and Pacific blue marlin using body weight, sagittae weight, and age estimates. Journal of Experimental Marine Biology and Ecology 151, 209-225.

Wilson, P.C., Bruce, R.A., Stevenson, W.H., Dixwell Chase, E., 1965. Cruise report, MV Delaware cruise 65-3; March 30 - April 23, 1965. Exploratory Fishing and gear research base, Bureau of Commercial Fisheries, Fish and Wildlife Service, US Dept. of Interior, Gloucester, MA.

Worm, B., Tittensor, D.P., 2011. Range contraction in large pelagic predators. Proceedings of the National Academy of Sciences 108, 11942-11947.

Yabe H, Ueyanagi, S., Kikawa, S., Watanabe, H., 1959. Study on the life-history of the swordfish, Xiphias gladius Linnaeus.Rep. Nankai Reg. Fish. Res. Lab. 10, 107-150.

Yaragina, N.A., Marshall, C.T. 2000. Trophic influences on interannual and seasonal variation in the liver condition index of Northeast Arctic cod (Gadus morhua). ICES Journal of Marine Science, 57, 42-55.

Zaitsev, Y., 2003. Bluefin tuna in the Black Sea. Workshop on Farming, Management and Conservation of Bluefin Tuna (Eds.: I. Oray and F.S. Karakulak), Turkish Marine Research Foundation, Istanbul, Turkey, Publication No: 13: 118-119.

Zijlstra, J.J., 1973. Egg weight and fecundity in the North Sea herring Clupea harengus. Netherlands Journal of Sea Research 6, 173-204. 


\section{Figure legends}

Figure 1. International fisheries landings in NE Atlantic (FAO area 21) and NW Atlantic (FAO area 27) from FAO (2010). FAO area 27 covers from $90^{\circ} \mathrm{W}$ to $42^{\circ} \mathrm{W}$ and from the North pole down to $35^{\circ} \mathrm{S}$; FAO area 21 is from $42^{\circ} \mathrm{E}$ to $68.5^{\circ} \mathrm{E}$ and from the pole down $42^{\circ} \mathrm{S}$.

Figure 2. Map of important physical oceanographic features in North Atlantic, with coloured arrows illustrating major currents: Gulf Stream, North Atlantic Current (NAC); Continetal Shelf Current (CSC); Eastern Greenland Current (EGC); Labrador Current (LC); Western Greenland Current (WGC); Subarctic Front (SAF).

Figure 3. Schematic map of feeding areas of adult parts of key pelagic fish species in the North Atlantic. 
1
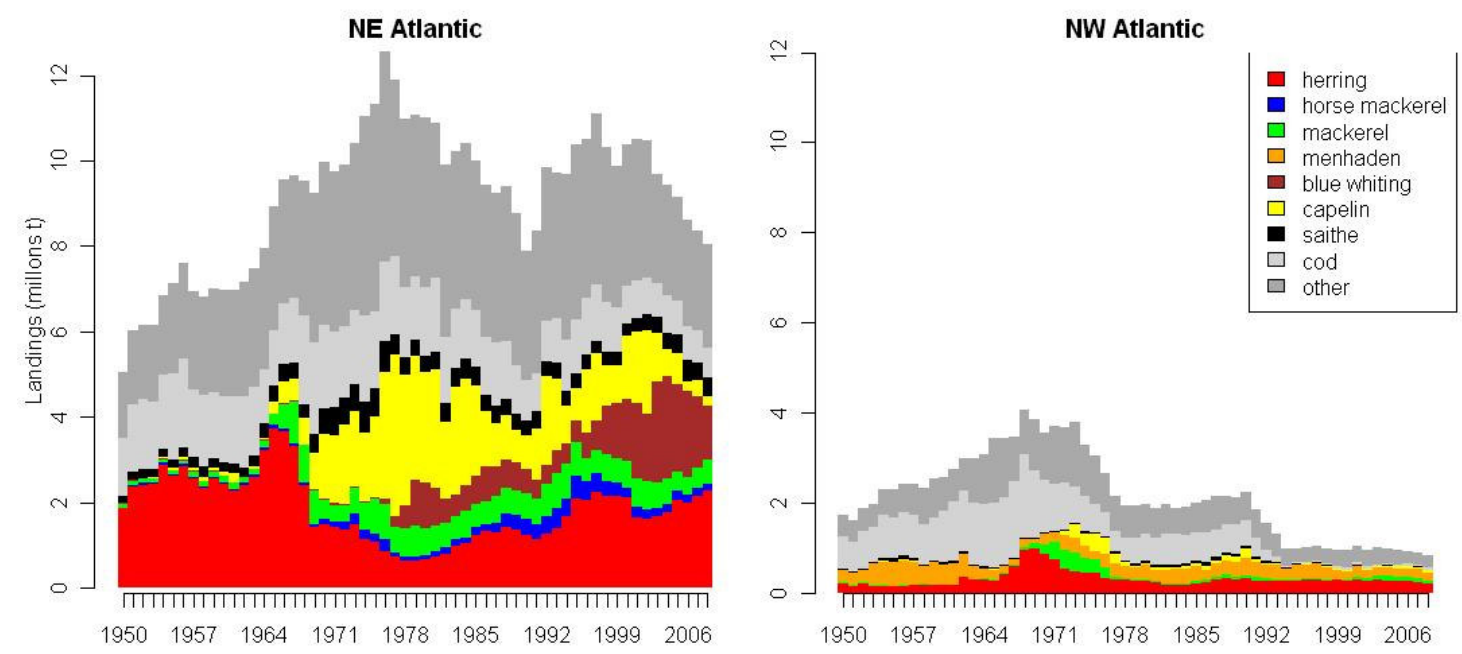

2
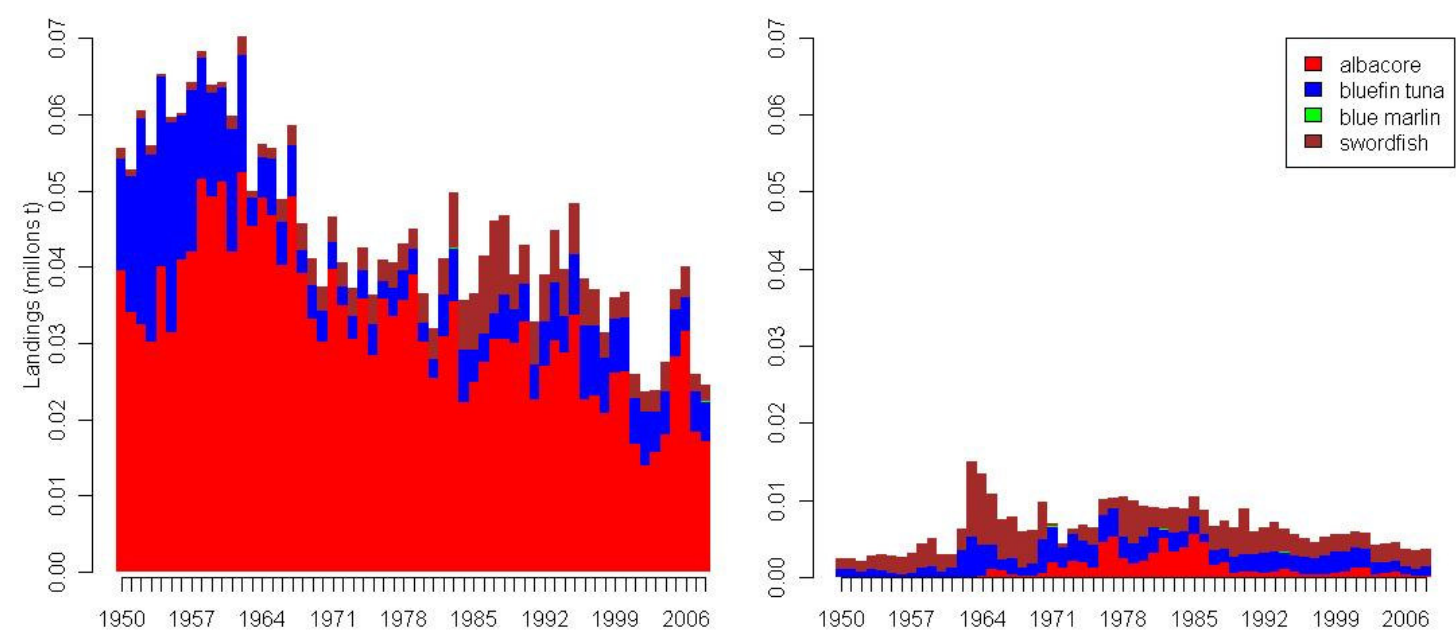


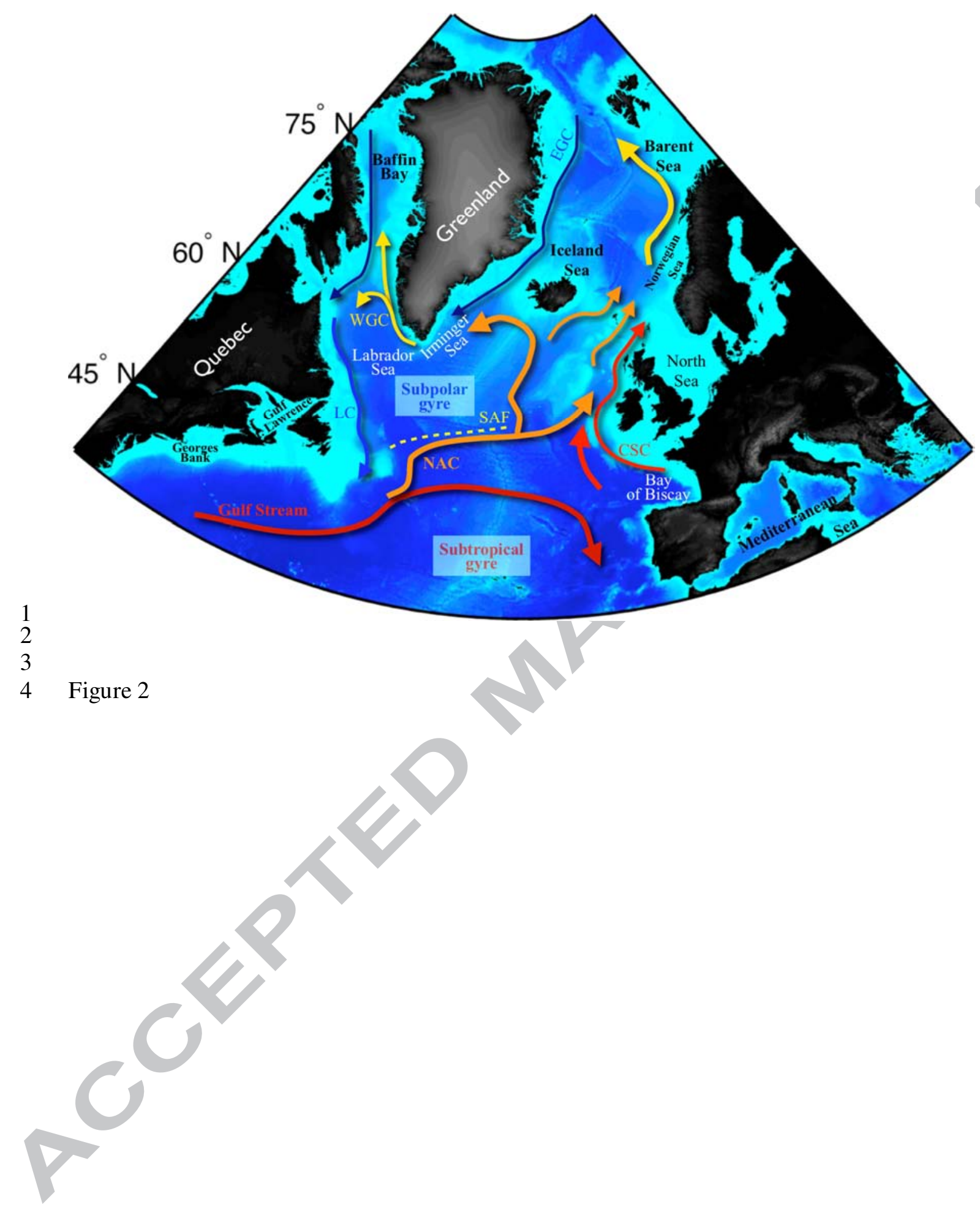




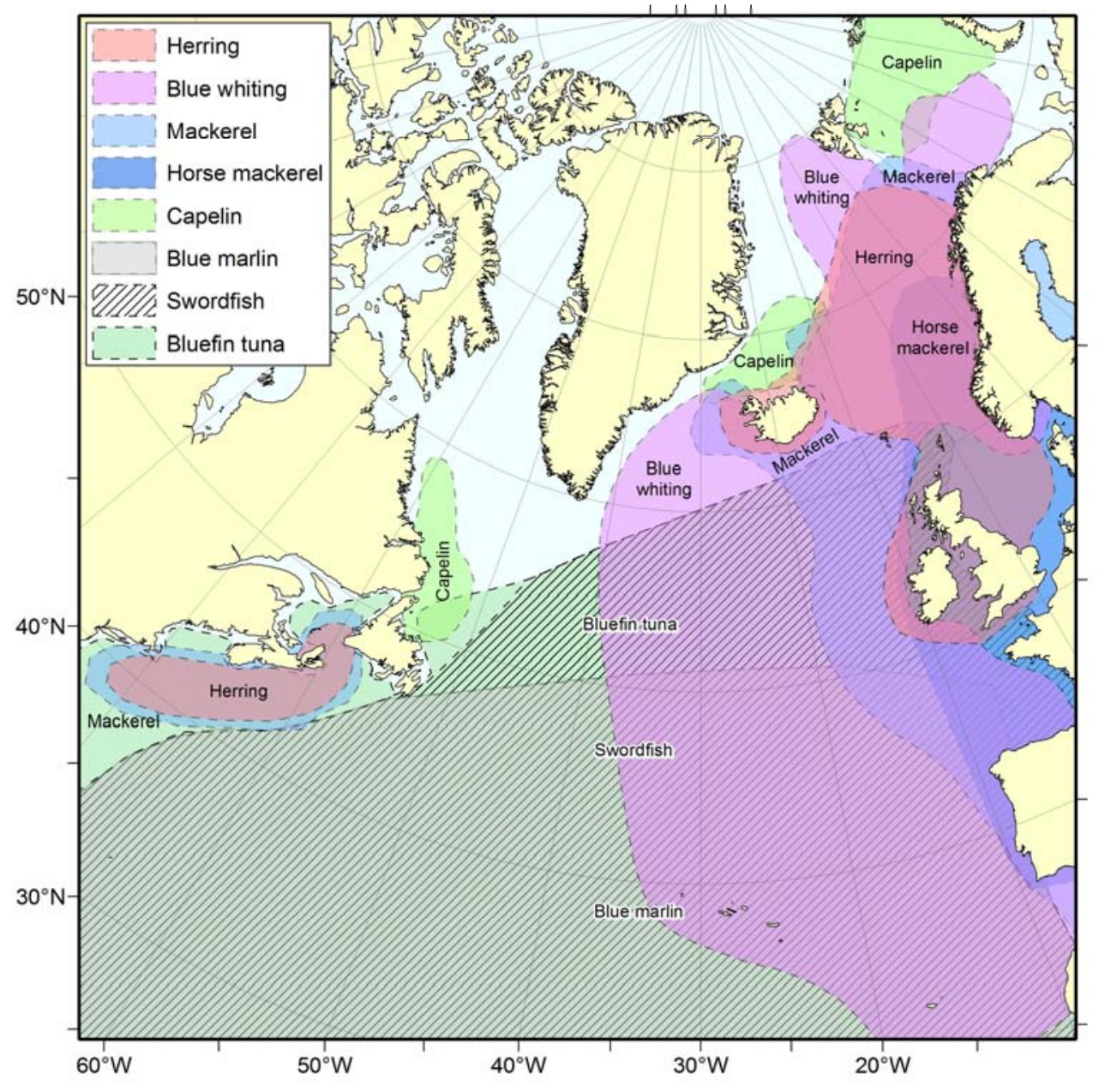

$\begin{array}{ll}2 & \\ 3 & \text { Figure } 3\end{array}$ 
Table 1. Summary of current knowledge of environmental and biological drivers for life history and spatial distribution as well as food web roles and interactions for selected small and large pelagic species in the North West and North East Atlantic (NEA). Major knowledge gaps are identified.

Environmental drivers: temperature (T), salinity (S), large scale oceanographic pattern $(\mathrm{O})$ (incl. NAO, wind, turbulence), oxygen (O2).

Biological drivers: density dependent (D), body condition/prey availability (B), predation pressure (P), unknown (?).

Food web role/control of species: top-down effect of species on its prey; bottom-up effect of species on its predators; resource or predator impact on species population dynamics; competition; ? suspected.

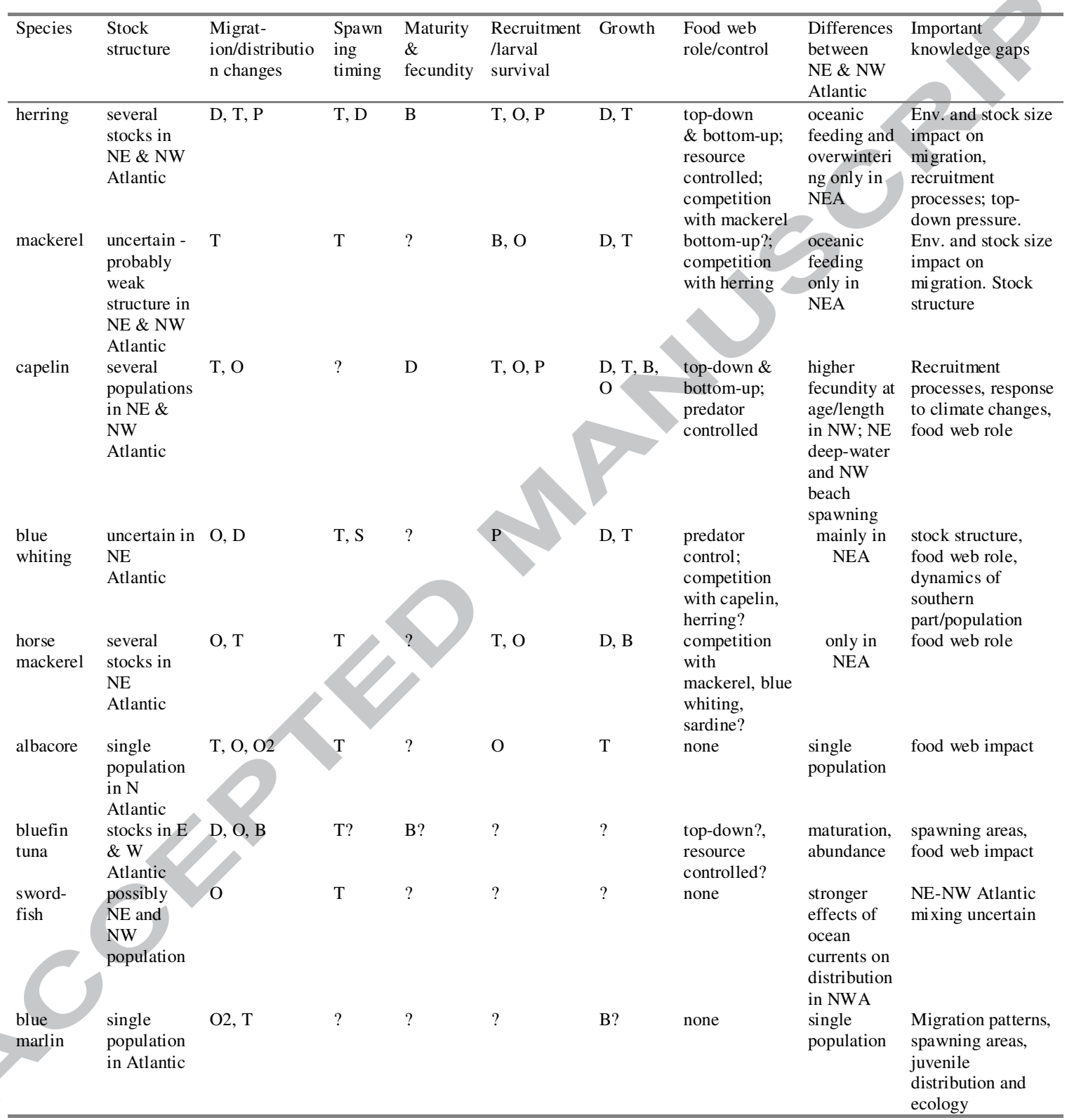

11

12

13

14 